Pace University

DigitalCommons@Pace

$1-1-1982$

\title{
The Relationship of Contractual Remedies to Political and Social Status: A Preliminary Inquiry
}

David S. Cohen

Pace Law School

Follow this and additional works at: https://digitalcommons.pace.edu/lawfaculty

Part of the Contracts Commons, and the Legal Remedies Commons

\section{Recommended Citation}

David Cohen, The Relationship of Contractual Remedies to Political and Social Status: A Preliminary Inquiry, 32 U. Toronto L.J. 31 (1982), http://digitalcommons.pace.edu/lawfaculty/428/. 
'And you see', Trollope makes Archdeacon Grantley say, 'land gives so much more than rent. It gives position and influence and political power, to say nothing about the game.'

What things 'give' is the very heart of the law of property. And what agreements 'give' is equally at the heart of the law of contract. No legal system could hope to develop at all unless it established rules defining the remedies available to enforce agreements or, put another way, insisting that one 'gets what one has been promised.' However we choose to define the substance of consensual obligations, we must include a reference to enforceability. ${ }^{2}$

An individual who has had his contractual expectations shattered and goes to law in order to obtain compensation or performance premises his claim on the destruction of his perceived wealth, represented by his personal expectation of profit created at the instant of agreement. ${ }^{3}$ Both parties stand to gain by the exchange through the enjoyment of their respective profits which did not exist prior to the bargain. This loss of expected profit - which inheres in every exchange, ${ }^{4}$ but which need not necessarily take the form of financial reward - may be protected through a variety of legal and non-legal means; the former include the application of punitive sanctions, the imposition of a specific legal duty on the promisor ordering him to perform, or the imposition of a general legal duty mandating a transfer of money damages, in an amount objectively assessed by public authority. Traditional contract law has shown a well-entrenched predisposition towards the imposition of liability to pay damages, reflecting, one suspects, a philosophy of individualism which, while it provides the foundation for freedom to contract, at the same time nurtures a concomitant freedom to breach. ${ }^{5}$

Thus even a preliminary inquiry as to the legal consequences of contractual failure reveals that the choices open to an individual to whom a consensual obligation is owed, upon discovering that the promised performance is not forthcoming, are both limited and well established.

* Faculty of Law, University of British Columbia

$\dagger$ Because of the length of the footnotes to this article, they may be found in a section beginning on page 74 .

(1982), 32 UNIVERSITY OF TORONTO LAW JOURNAL O31

$0042-0220 / 82 / 0100 / 0031 / \$ 1.25 / 0$ ㅇ University of Toronto Press 
He can, in some cases, demand that the promise be performed precisely (leaving aside the issue of temporal dislocation) as agreed - the archetypical suit for delivery of the subject-matter of a contract of sale and the complementary action for the price. More commonly, society may limit contractual redress to a claim for monetary compensation for losses suffered as a consequence of the failure to perform. ${ }^{6}$ Why, one might ask, does society, through the medium of the law, sometimes restrict the choice to a substitutionary damage claim and yet in other cases allow, indeed in some instances compel, the claimant to insist on performance?

A number of related theories have been proffered with varying degrees of success as possible analytical foundations for the primacy of damages in the common law of contract. The arguments have ranged from the protection of third-party claims in the case of executory contracts, ${ }^{7}$ tautological reliance on the recognition of equitable interests protected by equitable remedies, ${ }^{8}$ protection of individual liberty, ${ }^{9}$ administrative costs, ${ }^{10}$ judicial deference, ${ }^{11}$ and costs of valuation of market and non-market goods ${ }^{12}$ to the distributive implications of specific performance with respect to the relative wealth of the contracting parties. ${ }^{13}$

A recent contribution to this collection of doctrinal and interdisciplinary theories, or at least a different way of posing the question, has been offered by Calabresi and Melamed. ${ }^{14}$ They suggest that one can identify the nature of legal entitlements (or rights) as a consequence of the legal rules - including property rules, liability rules, and inalienability rules which have evolved to protect and regulate the creation, use, transferability, destruction, and other attributes of entitlements. A right or entitlement, let us say the right to privacy, may be said to be protected by a property rule if we allow appropriation of it by another only after bargaining; the taker must, before he deprives the present possessor of the entitlement of it, negotiate a purchase price. Thus when society protects a property right, it is not simply granting the owner of the right certain privileges with respect to the entitlement; it is actively forcing non-owners to refrain from interfering with the enjoyment of the right by its owner, unless the owner voluntarily consents to the interference. This consent to interference, if it is exacted in return for money, goods, services, or any other thing of value, consists of a bargained exchange whereby property is distributed and allocated among members of society. When we insist on this kind of negotiation we may be said to recognize a property right in the object. Other entitlements (or in other instances, the same entitlement in a different setting) are protected by liability rules, in which case the taker need not negotiate a price but must compensate the owner for the harm occasioned by the taking or interference. The classical examples given of this kind of entitlement are nuisance and negligence, 
where, in many instances, because of the numbers of interested parties, the unintentional nature of the taking, or the imbalances in negotiation brought on by free riders and holdouts, ${ }^{15}$ the costs of negotiation are prohibitive, foreclosing any realistic attempt at imposing property rules to protect entitlements. Finally, some entitlements, such as the right to life under most circumstances, are protected further by inalienability rules the owner cannot sell, and the taker cannot lawfully take, with or without bargaining or ex post compensation.

In a recent article, Kronman carried this analysis one step further, applying Calabresi and Melamed's thesis to contract entitlements:

In contract law, a liability rule permits a promisor to breach his promise provided he compensates the other party by payment of money damages. The fundamental alternative to money damages, in the law of contracts, is specific performance. A promise may be said to be specifically enforceable when the law gives its owner, the promisee, a right to require the actual (or 'specific') performance of the promise. The right to positively enjoin a promise, like the right to negatively enjoin a nuisance, may be viewed as an entitlement protected by a property rule. In both cases, the owner of the right is in a position to force the would-be taker to negotiate a voluntary transfer of the particular entitlement. If the taker acts unilaterally (by simply refusing to perform, or by continuing to pollute), he can be compelled by an injunctive order to honour the owner's entitlement; and if he then refuses to honour the injunction itself, he may be forced to make a payment (not necessarily pecuniary) to the state or the promisee greater than that required to compensate the promisee for this loss. ${ }^{16}$

Bentham long ago made a similar point: 'Property is nothing but the basis of expectation: the expectation of deriving certain' advantages from a thing, which we are said to possess, in consequence of the relation in which we stand towards it. ${ }^{17}$ Applying Bentham's thesis to the thing of contract, one can quite readily perceive that contractual expectations are accorded widely diverse treatment in law. There is no doubt that all contractual entitlements are, at least in theory, valuable - the owner can assign the entitlement, receiving an immediate return rather than engaging in the risk and delay inherent in an executory transaction. He may, if a stranger interferes, obtain compensation for inducement of a breach of his contract which interferes with his expectations coming to fruition. And if his promisor fails to perform, he can often recover damages to compensate him for his losses. This wealth, however, is not property. It is property only if the law offers him the right to its continued existence, rather than mere compensation for its loss. As I have noted, however, this is not usually the case: 'Expectances are for most purposes not treated as property. ${ }^{, 18}$ 
Yet Calabresi and Melamed's contentions, with respect to the low cost of negotiation operating as an overriding incentive to the recognition of property rights (ie, the protection of entitlements by property rules), seem particularly apt in the contractual context. As Kronman points out, a priori the parties to the contract know one another, and thus one need not concern oneself with questions of search and identification, ${ }^{19}$ and many contracts, since they involve only two parties, obviate the difficulties caused by holdouts and free riders. For these reasons and others, one might have suspected that specific performance would have evolved as the preferred remedy in contract law. This has not been so, and it is obvious that other forces have been at play in the recognition and protection of contractual expectations through liability rules. The only species of contract that conforms to Kronman's analysis is the contract for the purchase and sale of real property. The most prominent exception to liability rules in contract - the specific enforcement of contracts relating to land - constitutes perhaps the final vestige of the historical subordination of contract to property. ${ }^{20}$ Contracts relating to land create performatory obligations 'as a matter of course. ${ }^{21}$ But, of course, land is not 'unique' in any sense which would deny absolutely the capability to assess damages. Market prices (of a sort) are available to the courts in determining value, and notwithstanding ample evidence that the protection of entitlements by property rules may be explained by institutional limitations reflected in a judicial disinclination to engage in valuation in the absence of a market, incongruities in the law suggest that the foundation for the evolution of property rules to protect contractual entitlements must be found elsewhere. $^{22}$

Perhaps specific performance in respect of land - the protection of real contractual entitlements by property rules - is not grounded in 'uniqueness,' liberty, or the avoidance of valuation errors. When one looks beyond the boundaries of specific performance one is immediately struck by the variety of relationships ranging from the treatment of parol contracts under the Statute of Frauds ${ }^{23}$ and special rights made available to defaulting mortgagors ${ }^{24}$ to the application of criminal sanctions to violations of contractual expectations, ${ }^{25}$ which, where they involved the transfer of land, were so often imbued with bizarre legal characteristics. This diversity of judicial and legislative behaviour suggests that the rationale for the creation of property rights in contracts relating to land must be found elsewhere than in mere difficulties in assessment of value.

Too many of us have been naively comfortable with a rule which authorizes a court to order specific performance (that is, to recognize property rights in contract) whenever it is just, or fair, or equitable, or reasonable to do so. Justice, fairness, equity, and reasonableness are, of 
course, values to which the law has aspired and which it will seek to achieve for eternity. The obvious difficulty with reliance on what we may call justice language is that the meaning of these concepts to one person is often precisely the opposite to that attributed to them by another. The language of justice and fairness is meaningless unless one gives it content. The traditional jurisprudence touching on the remedy of specific performance does offer some insight as to the underpinnings of justice. As I have outlined briefly, the 'uniqueness' of the object of the contract, the administrative costs of assessing damages, the risks of overcompensation or under-compensation, difficulties of mitigation, and the 'inadequacy' of damages are the most common judicial rationalizations for ordering specific performance. More recently, as I have described, followers of economic analysis of law have offered more detailed explanations for ordering performance of contractual obligations. I hope in this essay to offer a somewhat different perspective on the foundations for the creation of property rights in contracts relating to land. No doubt the common law and economic explanations (assuming a difference to exist) are not entirely without merit. Nonetheless, the ancient and pervasive relationship of land ownership with political identity, legal authority, and social status suggests that the rules relating to bargained exchanges of land may have some deeper meaning. My assumption, of course, is that the law of contract could not have developed in total isolation from the political, economic, and social values of the society which gave meaning to property. My task, however, is not merely of academic or historical relevance. If in fact the law has protected expectations under land contracts through specific performance, in implicit recognition of the non-economic political and social attributes of such exchanges, then if other kinds of contracts are now imbued with political and social attributes, we must seriously question whether property rules should be extended to reflect this transformation in cultural values.

This paper has, then, two major themes. In the first part I hope to elucidate the relationship of political, legal, and social status associated with land ownership to the unique legal remedies - specific performance and non-recovery of damages - which society created in respect to exchanges of land (and thus exchanges of status) for money. In the conclusion I examine the transformation of legal rules applied to agreements in which labour is exchanged for money. If, in fact, property rules in contract evolved in response to the political, legal, and social attributes of land ownership, then one may be able to perceive a metamorphosis in the nature of labour entitlements as the meaning and place of labour in society has evolved. I should point out as well that the purpose of this essay is not to deny that land contracts ought no longer to be protected by 
property rules. It is less ambitious than that. My intent is to point out that many of the underlying social and political forces which created the traditional boundaries of specific performance are no longer extant. Other contracts which have nothing at all to do with real property may have replaced, or at least joined, land contracts as the focal point of social expectations and obligations. Wealth exists in numerous guises, many of which were unknown or even illegal when contract law developed in the eighteenth and nineteenth centuries. Private property, be it in tangible assets or contracts, is a delicate institution. If the law closes its eyes to social change and protects only one form of wealth to the exclusion of all others, it exists only to protect those who possess the former.

Where, then, does one look for guidance in order to uncover the forces underlying the evolution of property rules in contract? What is this vast difference, this great 'moment' or 'special or fancy value' which justified the protection of contractual entitlements through property rules even where market value was ascertainable? One must search, it seems, outside the sphere of economic expectations - to understand the place of land in the constitutional, political, and social institutions of England during the formative stages of its legal development - if one is to appreciate fully the significance and role of property rules in respect of promissory entitlements. Maitland, writing in 1908, remarked that England's 'whole constitutional law seems at times to be but an appendix to the law of real property. ${ }^{, 26}$ One might equally posit that England's law of real property and contract is but a reflection of its constitutional law. This curious admixture of property rights, civil status, and political authority born of centuries of feudal economy and government remains hidden beneath the surface of the law, resulting in an intricate intermingling of private and public rights (and law). Only when it is examined closely does one grasp the subtle interests and influences which lie beneath apparent irrationality and arbitrariness.

Our starting point in such an inquiry must be to acknowledge at least two implicit assumptions under which money damage awards are made. First, the protection of promissory entitlements by liability rules may presuppose an economic foundation for the contract. ${ }^{27}$ Second, it presumes the acceptability, in terms of popular cultural and social values, of public and collective monetization of the value of the owner's losses. If, in fact, we do not find the objective valuation of certain objects acceptable in terms of our social and cultural mores, or if the promissory entitlement has as its object the transfer of something other than economic wealth, then liability rules, involving an award of money damages, may succumb to the institution of property. The protection of promissory entitlements involving land evolved during the seventeenth and eighteenth centuries, 
indeed had become fixed, as property rules, by the turn of the nineteenth century; and if one is to appreciate fully the rationale for this unlikely occurrence, one must understand the cultural, social, economic, and political values of those times. ${ }^{28}$

We begin with the obvious. Few would argue with the proposition that land constituted the most important form of economic wealth prior to the industrial revolution in England: 'A wealthy man was one who had extensive holdings in land, the landless man was of little account. ${ }^{29}$ The prcuection of promissory entitlements in respect of land evolved in an age where the leading authority on real property could write in terms almost incomprehensible to the modern mind:

In the early ages of Europe, property was chiefly of a substantial and visible, or, what lawyers call, a corporeal kind. Trade was little practised, and consequently debts were seldom incurred. There were no public funds, and of course no funded property. The public wealth consisted principally of land, and the houses and buildings erected upon it, of the cattle in the fields, and the goods in the houses. Now land, which is immovable and indestructable, is evidently a different species of property from a cow or a sheep, which may be stolen, killed, eaten; or from a chair or a table, which may be broken up or burnt.

There is now perhaps as much personal property in the country as real; possibly there may be more. Real property, however, still retains many of its ancient laws, which invest it with an interest and importance to which personal property has no claim. ${ }^{30}$

Protection of entitlements in respect of land evolved in a society whose entire economic foundation was 'based and centred on land.'31

Of equal or greater importance is that the economic characteristics of land as they existed in the seventeenth and eighteenth centuries were radically different from those which exist today. It has been said, for example, that the aggregate value of land in the 1800 ' remained in real money terms, about the same as it was in ... 1066, ${ }^{22}$ and Dicey, explaining the failure of nineteenth-century land reform in England, wrote at the end of that century that 'land is not a lucrative investment.'33 Corbin's rationale for the emergence of the rule in Bain $v$ Fothergill ${ }^{34}$ denying recognition of a purchaser's expectation interest on breach of a contract for the sale of land suggests that land in England was not purchased in the hope of a rapid appreciation in price. ${ }^{35}$ In 1894 Mayne, writing of the time at which damages are to be assessed for breach of an executed contract to sell land, was unable to find any English authority on the right of the purchaser to recover the appreciated value of the land at the time of eviction, instead reviewing the considerable American authority on point. ${ }^{36}$ This stability in land prices was openly acknowledged by the judiciary. In 1786, the Supreme Court of Connecticut justified its 
reluctance to adopt an English principle restricting damage remedies in respect of land contract in the following terms: 'the diversity ... between British practice and ours is undoubtedly founded in the permanent worth of their land, as an old country, and the increasing worth of ours as a new country. ${ }^{37}$

While land may have been in demand during the seventeenth and eighteenth centuries, ${ }^{38}$ the incentives for contracting were apparently not pecuniary.

The seventeenth century merchants who bought land were diverting capital into an investment that promised no better than a five percent return. Had they left their money in the city, they could have been assured of a ten percent return. These individuals were willing to accept a lesser income because they coveted the prestige that went with the land. The new men were more interested in behaving like landed gentlemen than in earning the kind of profit that would lure a true capitalist. The landed gentlemen remained the ideal to which all propertied classes aspired. ${ }^{39}$

For the most part expected economic returns on capital investment in land were generally 'not as high as those to be earned from commerce, finance and office-holding. ${ }^{\prime} 4^{\circ}$ The agricultural purposes to which land was put, the practice of granting only leases at will which destroyed any incentive in the landlords' tenants to improve their lot, and the doctrine of primogeniture which gave the land to the landowner's eldest son only, while allocating the capital resources which would allow its improvement to the younger children, led Mill to conclude the 'Landed Property in England is ... very far from completely fulfilling the conditions which render its existence economically justifiable. ${ }^{4{ }^{1}}$

The stability of land prices in England can be contrasted with the speculative characteristics of the land economy in North America. In America, land was bought and sold in relative freedom, at least in part because of its seemingly infinite supply during the post-revolutionary era in the United States and, until far more recently, in Canada..$^{42}$ As early as 1824, a majority of the New York High Court of Errors noted that 'every member of this Court must be well aware how much property is held by contract; that purchases are constantly made upon speculation; that the value of real estate is fluctuating, ${ }^{\prime 3}$ and Chancellor Kent spoke of the ruinous and oppressive injury which would be incurred by a seller of land if he were to be held liable to a purchaser for the rise in value of the land if a defect in title were discovered in the future. ${ }^{44}$ Land in Canada was subject to similar appreciations in price brought on by the combined forces of urban development and immigration during the nineteenth century. ${ }^{45}$ 
As history all too clearly teaches us, the agrarian economy of preindustrial England, the political and social exploitation of the non-landed citizen, ${ }^{4^{6}}$ the stagnation of land, as a matter of both insecurity of ownership and retrenchment by the landed aristocracy and gentry, ${ }^{47}$ and the 'burdensome expenses imposed on transactions in land by the common law and its lawyers' ${ }^{\mathbf{4}}$ reflect a political, social and economic climate far narrower in focus than today. Lord Jeffrey's 'earth hunger'49 and Lord Nottingham's reaction to the plight of a mortgagor which 'cried aloud for the protection of the Court of Chancery' $5^{\circ}$ call attention to the emotional reactions evoked by land ownership during the formative years of contract law.

This status, which underlies the discontinuity between the legal treatment of land contracts and all others, may rest to a large degree on the political attributes of land ownership - ownership which, for over four centuries, was inextricably entwined with political power and identity. The purchase of land was, to put it in its most graphic form, the purchase of the right to vote. Lord Mansfield, speaking of the rights of the holder of legal title to land in $\mathbf{1 7 5 2}^{2}$, described '[a] special privilege of the highest benefit annexed by the common law to the possession of land ... the right of voting for coroners, sheriffs and members of parliament. ${ }^{5^{1}}$ Daniel Defoe, writing half a century earlier, felt it necessary to withhold political rights from mere inhabitants. The right to enact law through representation was vested 'upon the Freeholders; the Freeholders are the proper Owners of the Country ... the other Inhabitants ... ought to be subject to such Laws as the Freeholders impose upon them ... because the Freeholders having a Right to the land, the other have no right to live there but upon sufferance. ${ }^{2}$

The identity of the franchise and ownership of land had its source in legislation enacted in 1430 which restricted ${ }^{53}$ the English parliamentary franchise in county elections to residents who held title to "free Land or Tenement of the Value of Forty Shillings by the Year. ${ }^{54}$ The enactment was demonstrably for the purposes of political stabilization, its avowed intent being to eliminate the disorder which then accompanied elections. ${ }^{55}$ The express reason for the act was to disenfranchise the 'outrageous and excessive Number of People ... of small substance and no value' who would otherwise have participated in the electoral process. ${ }^{56}$ Others have suggested the reactionary mood of the king and Parliament and political self-interest on the part of the fifteenth-century parliamentarians as foundations for the restriction. ${ }^{57}$

To ascertain the import in modern terms of a forty-shilling annual income from land in the fifteenth century is almost impossible. Not only has the meaning and value of money changed, but if one assumes that 
value is determined by the choices made by individuals in choosing among various goods, the transformation of society from a local agrarian economy to an international industrial, commercial, and consumer economy forecloses meaningful comparisons. Nonetheless, attempts have been made. Blackstone calculated that forty shillings in the region of Henry vi $(1422-60)$ was equivalent to twenty pounds in $1765,,^{58}$ and in 1898 the fifteenth-century franchise requirement was estimated at thirty to forty pounds. ${ }^{59}$ While there have been a number of similar rough estimates, if not outright guesses, at the meaning of a forty-shilling freehold in $1430^{6 \circ}$ its true import can best be understood if one considers that it is said to have disenfranchised hundreds of thousands of leaseholders, copyholders, and freeholders of land with annual rents of less than the stated requisite, leaving an electorate of perhaps ten thousand. ${ }^{61}$ Similar legislation today would be nothing less than dictatorial. ${ }^{62}$ Although the forty-shilling freehold voting requirement applied uniformly in the counties, suffrage in the boroughs, which in time returned a far greater percentage of the Commons, was notoriously idiosyncratic. $^{6}{ }^{6}$ Franchise qualifications were determined autonomously, in some cases extending to members of the borough council, in others to all freemen, and in still others to holders of burgage tenements, to potwallers, or to those who paid 'scot and lot. ${ }^{64}$ In general the franchise was restricted, the traditional philosophy being to retain political power in the hands of the few. ${ }^{65}$

An unquestionable consequence of the forty-shilling freehold voting requirement was the establishment of a narrow class of enfranchised landowners; one historian estimated the average county electorate at only 4000 , returning two members of Parliament in $1760 .{ }^{66}$ The aggregate county electorate in 1760 is said to have consisted of only 170,000 persons and had risen to 188 ,ooo in $1831 .{ }^{67}$ Although increases in population and the practice of transferring land to create votes did operate to enlarge the electorate to some degree during the seventeenth and eighteenth centuries, the consensus seems to be that the numbers enjoying the electoral franchise in fact failed to keep up with the expansion of the population. ${ }^{68}$ While the real value of forty shillings per year, measured in terms of the goods which it could purchase, may have fallen dramatically over the centuries, 'the decline in the number of individuals holding land by Freehold, because of the growth of vast landed estates, tended to keep the rural electorate comparatively small. ${ }^{, 69}$ The picture drawn of the borough electorate is no prettier..$^{\circ}$ One of the more generous estimates of the electorate suggests that 3 or 4 per cent of the population was enfranchised prior to $1832,7^{71}$ while another concludes that only 465,000 persons of a population of over $24,000,000$ were enfranchised in the election of $1830 .^{72}$ 
The disenfranchisement of all but a narrow political elite was mirrored in the nature of land ownership - hardly a startling discovery when, in essence, ownership of land constituted, and thus parallelled, ownership of the vote. One likely explanation of the limited membership of the political and land-owning class is that vast tracts of land were held by copyholders, who were not enfranchised until the nineteenth century. ${ }^{73}$ Pollock has suggested that in the sixteenth century a third of England was copyhold, ${ }^{74}$ and copyholders, through sheer numbers, constituted an important class of the English population. ${ }^{75}$ While the nature of land holdings evolved over the centuries, the purchase of freehold land remained the only avenue of entry to the narrow political élite. Even during the latter part of the nineteenth century the claim was made that 'the great English nation is tenant at will to a few thousand landowners. ${ }^{76}$ Bonbright concludes that in 1874 there were only $15^{\circ}$,00o citizens who owned more than one acre and argues that this accords well with others who suggest that the entire population of landowners numbered some $160,000 .{ }^{77}$ Whatever the true numbers may have been, there can be no doubt that land ownership and the supply of votes were kept to an absolute minimum. The result was, as we shall see, precisely what one might have expected in the case of any valuable good whose supply is kept down by artificial means.

The limited franchise remained in force, with but one exception during the Commonwealth from 1653 until $1660,{ }^{7}$ for almost four centuries. In 1832 , the county franchise was substantially extended and some degree of uniformity established in the borough franchises, under the Reform Act, $1832^{79}$ which, while it left extant the forty-shilling qualification, extended the franchise to a wider range of real property interests..$^{80}$

Constitutional law in Canada suffered from the same inegalitarianism. The Constitution Act of ${ }^{1791^{89}}$ was not far removed from its English parent - while it did not institute a property qualification for membership in the Legislative Council or Assembly, it limited the franchise in counties to freeholders of land with a yearly value of forty shillings or its equivalent in any tenure..$^{\circ}$ In non-rural areas, suffrage depended upon ownership of a dwelling house and land valued at five pounds, or tenancy at ten pounds per year and residency for at least one year. ${ }^{91}$ Persons disqualified under provincial legislation were not entitled to vote for members of the Legislative Assembly..$^{22}$ No reforms were instituted under the Canada Union Act, ${ }^{93}$ and in 1849 the earlier acts were consolidated, ${ }^{94}$ with the property franchise and provincial disqualifications continued without substantial modification. The franchise was extended in 1853 and 1854 to owners, tenants, and occupiers of land with an assessed value of $\$ 200$ or a yearly value of $\$ 20$ in townships, or with an assessed value of $\$ 300$ or a yearly value of $\$ 30$ in towns. ${ }^{95}$ 
At Confederation, these qualifications were in force in Ontario and Quebec, ${ }^{96}$ and similar property qualifications were required of voters in Nova Scotia ${ }^{97}$ and New Brunswick. ${ }^{98}$ After Confederation, the federal electoral franchise continued to be determined according to provincial franchise qualifications, which for decades remained co-extensive with ownership of real property. ${ }^{99}$ Ward has calculated that the electorate in the federal parliamentary elections in 1872 approximated only 15 per cent of the populations of Ontario, Quebec, Nova Scotia, and New Brunswick. ${ }^{100}$ This form of representational democracy based on land ownership was hardly ameliorated by minor reforms in electoral laws (and, one may presume, by reforms in land ownership), and a decade later the parliamentary franchise remained strictly circumscribed, ranging from 20.2 per cent in Ontario to 11 per cent in British Columbia and to 16.6 per cent in Quebec. ${ }^{101}$

The provincial tendency to abrogate property qualifications and the federal government's illiberal views on electoral democracy ${ }^{102}$ led to the introduction of the first federal Electoral Franchise $\mathrm{Act}^{103}$ in 1885, which, with minor exceptions in British Columbia and Prince Edward Island, ${ }^{104}$ instituted a nation-wide property qualification. Under section 2 of the act, the franchise was vested in any male who owned real property in his own right, or in right of his wife, and who was in actual possession of the land or in receipt of the rent and profits from it. ${ }^{105} \mathrm{~A}$ woman's vote (or rather the vote of a woman who may have held land as a beneficiary) was exercisable by her husband. ${ }^{106}$

Constitutional jurisdiction to regulate the allocation of the federal parliamentary franchise after 1885 - since the franchise continued to depend on ownership of property ${ }^{107}$ (traditionally a matter within provincial jurisdiction) - raised some debate during the early years of Confederation. However, in 1891 the issue was resolved in favour of the federal government when the Ontario Divisional Court, Chancery Division, affirmed federal legislative authority:

This legislation does not trench upon 'property and civil rights in the Province'... The subjects of this class of legislation are of a political character, and ... distinct ... from matters of civil rights in the Provinces which regard mainly the meum and tuum as between citizens. It is in my view rather confusing to speak of the right of voting as comprehended under the 'civil rights' mentioned in sec. 92 sub-s. 13 of the B.N.A. Act. This franchise is not an ordinary civil right; it is historically and truly a statutory privilege of a political nature, being the chief means whereby the people, organized for political purposes, have their share in the functions of government. ${ }^{108}$

Provincial authority to determine the federal parliamentary franchise was restored in $1898^{109}$ and retained until $1917 .{ }^{110}$ In 1920 a new federal act 
was promulgated, and civil personality became the touchstone of political identity. ${ }^{111}$

The political philosophy that land, not civil personality, was represented in Parliament is presented most vividly by the political status of women who held land. Although there is some dispute as to the absolute right of women to exercise the vote in England, a number of commentators take the view that, until the nineteenth century, women did 'return ... members of parliament, ${ }^{112}$ and several cases decided during the seventeenth century make this point without reservation. ${ }^{113}$ Whatever may have been the case in England, there is little doubt that women did enjoy the franchise in the Canadian provinces during the early years of the nineteenth century. ${ }^{114}$ Those who adopt a more conservative stance admit that prior to 1832 a woman could transfer her vote to her husband, a son, or another close relative ${ }^{115}$ and that 'a vote in respect of the property'116 could not be cast away merely on the gender of who might have owned or possessed the land at issue. A husband could vote in respect of his wife's property unless the land was vested in trustees for her separate welfare, or where, after marriage, the property was settled on trustees for her separate use. In these cases the male could 'by no means vote in respect thereof." ${ }^{117}$ Legislation enacted to void the creation of votes through the vehicle of land transfer was never thought to have extended to the case of an estate which descended to 'any number of females, the husband of each having a right to vote if his interest amounted to forty shillings a year. ${ }^{118}$ In 1780 , after disputes arose as to the exercise of the franchise in respect of dower rights, legislation was promulgated which expressly enfranchised the husband of a woman who held dower rights at common law in respect of her former husband's estates. ${ }^{19}$ With the reformation of the franchise and the transformation of the right to vote from a function of land ownership to an attribute of civil status, women were disenfranchised. ${ }^{120}$

The political history of land ownership in England and Canada is central to an understanding of the development of contract remedies at common law and equity. The promissory entitlement represented by the contractual expectations inherent in an agreement to purchase land was defined not by the transformation of the purchaser's money into economic wealth in another form, and thus compensable in moneydamages, but rather by the achievement of political identity: '[M]ere wealth does not entitle a man to vote unless the wealth is converted into occupancy or a tenure of land.' ${ }^{121}$ The Commons represented not the public but rather property in the form of land, and a contract to purchase land represented a licence to political representation through property ownership. Although we would be wise to heed Holmes' admonition to take sceptically the axiom that 'land is capable of having rights, ${ }^{122}$ the 
social and political fabric of seventeenth- and eighteenth-century England lends considerable strength to the image that landed property was imbued with political rights exercised by the owner of fee, as it were, by

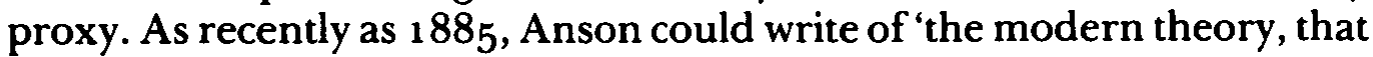
Property as such ... is entitled to representation, ${ }^{123}$ and in Anelay v. Lewis ${ }^{124}$ Jervis CJ said: "There is a qualification arising out of this piece of land. ${ }^{125}$ The concept of the franchise as equivalent to - one might even say indistinguishable from - ownership of freehold land has been said to be 'typical of the eighteenth century,' ${ }^{126}$ and one suspects that the assimilation of one to the other was such an integral part of political and social mores that few would think it necessary to make the point explicitly when recognizing political expectations through the enforcement of contractual rights in law. ${ }^{127}$ Nonetheless, legal actions and legislative intervention involving the franchise can be found, and it is here that we discover an express acknowledgement of the degree to which rights to vote, rights in land, and contract law had become inextricably entwined with one another.

Holt $\mathrm{CJ}$, in the now famous case of Ashby $\mathrm{v}$ White, ${ }^{128}$ considered the county freeholder's right to vote by reason of his ownership of land as a 'real Right, [and] in boroughs ... a real Right annexed to the tenure of burgage ... a noble privilege, which entitles the subject to a share in the government and legislature. ${ }^{129}$ Ashby $\mathrm{v}$ White involved a claim for damages arising on the malicious refusal of the plaintiff's vote by a returning officer in a parliamentary election; Holt $\mathrm{CJ}$ understood this illegal interference with the right to vote as giving rise to a 'cause of action on the property of the subject ${ }^{13^{\circ}}$ and thus being within the jurisdiction of the common law courts notwithstanding that it touched upon parliamentary matters. The identity of political status and title to land and the real nature of both were affirmed by the House of Lords:

[T] here is a great difference between the right of the electors and the right of the elected: the one is a temporary right to a place in parliament, pro hac vice; the other is a freehold or a franchise. Who has a right to sit in the House of Commons may be properly cognisable there; but who has a right to choose is a matter originally established, even before there is a parliament. A man has a right to his vote, having annexed the right of voting to his freehold, it is of the nature of his freehold, and must depend upon it. The same law that gives him his right must defend it for him, and any other power that will pretend to take away his right of voting may as well pretend to take away the freehold upon which it depends. ${ }^{191}$

Contractual rights to vote, if seen as rights of freehold or real rights, would have been enforceable by specific remedies - the distinguishing mark between real and personal rights: ${ }^{132}$ 'The Plaintiff has a right to the 
franchise and therefore the law would give a remedy for breach of that right." ${ }^{133}$

A second area where the intersection of contract law and political rights is evident is that of mortgages and the enfranchisement of purchasers of land prior to completion. From 1430 until close to the end of the seventeenth century only holders of legal title to land were entitled to exercise the franchise. This prerequisite left two substantial classes of persons disenfranchised, notwithstanding that they enjoyed inchoate rights in land. Neither purchasers of land whose contractual rights had not yet crystalized into full ownership interests nor mortgagors who had transferred legal ownership in their land as security for credit with the proviso that the conveyance should be void once their debt was paid in full could vote under the original franchise legislation. Delays in conveyancing were considerable in the seventeenth and eighteenth centuries, and so was the interference with a purchaser's expected exercise of the franchise, brought on by the complexities and uncertainties of the law of real property; Fry attributes the growth of the doctrine of specific performance to the disarray of titles of land: '[W] here contract is separated from conveyance by all the formalities and delay of an examination into title, and the preparation of a formal deed, [specific performance] would be a necessity to anything like a civilized system of law."134

Interference with acquisition of the right to vote was reduced considerably in 1696 . In that year the franchise was extended to prospective purchasers in actual physical possession of the land or in receipt of its rents and profits pending completion ${ }^{135}$ - the purchaser standing in the guise of a beneficiary in relation to the vendor as a trustee or quasitrustee. ${ }^{136}$ Thus, after 1696 political rights depended on the terms of the contract of purchase and sale, and specifically on the private allocation of physical possession or economic return prior to a transfer of legal ownership: 'If they belonged to the purchaser under such circumstances that he could compel a specific performance, the vendor was a trustee of the legal estate for him, he took an equitable freehold and had a right to vote. ${ }^{137}$ Over time, the recognition of the purchaser's equitable interest in the land and, more precisely, his right to specific performance became the explicit criterion for the electoral franchise: '[I]f a person has such an equitable title as the Courts will recognize, he is entitled to vote. As where there has been an agreement for sale and the vendee has taken possession under the agreement, or has become otherwise entitled to a specific performance of the contract.' ${ }^{38}$

One might surmise, easily enough, that mortgagors would have been similarly dissatisfied with electoral qualifications for different but equally persuasive reasons. If a purchaser of land gave a mortgage as security for 
the price, he did not, through mere acquisition of equitable ownership, acquire the vote; and if one already owned land, the mortgage became a tool of disenfranchisement if insufficient land was retained to meet the forty-shilling annual income qualification. ${ }^{139}$ Finally, even if a mortgagor retained sufficient land to vote, mortgage transactions resulted in a dilution of narrowly circumscribed political authority - where only the landowner could vote prior to the mortgage, both he and his creditor would be entitled to the franchise once legal ownership was transferred. In 1759 Lord Mansfield would openly acknowledge the transfer of the franchise as a predominant characteristic of the transfer of legal title by way of mortgage prior to $1696 .^{140}$

The political implications of what was rapidly evolving into a patently commercial transaction were altered in 1696 , with the enfranchisement of all mortgagors in possession of the land or in receipt of the requisite yearly value of forty shillings. ${ }^{141}$ Again political identity was dependent upon private, contractual allocation of rights to land, and it is not inconceivable that the mortgagee's contractual right to dispossess the landowner, as a private right of disenfranchisement, was modified by equitable doctrines in response to political reality: 'In popular parlance, the possession of the land without rack rent or receipt of rent is often made the test of ownership. As regards mortgages this is more practical than appears at first sight; for the mortgagee rarely takes possession save as a last resort, and such possession is therefore usually followed by sale, foreclosure, or the acquisition of a squatter's title. Likewise possession confers upon the party the parliamentary franchise. ${ }^{14^{2}}$

The intersection of the law of specific performance and the franchise, undisguised in the case of purchases and mortgages of real property, is revealed in a third context in the historical treatment in Equity of transfers of copyhold land. A contract to sell freehold land, which in truth was held only by copyhold, was not capable of specific performance. ${ }^{143} \mathrm{~A}$ purchaser would not have copyhold land forced on him even though it has been said that the ancient requirement that the lord of the manor consent to the transfer had become a mere formality by the end of the seventeenth century. It is true, nonetheless, that later contracts in respect of copyhold estates were ordered performed. ${ }^{144}$ Earlier, however, when copyholders were not enfranchised it had been held that an agreement to transfer a copyhold estate would not be enforced, ${ }^{145}$ and it has been said that '[a]t one time the Court hesitated to decree specific performance of an agreement relating to copyhold lands, in respect of the rights of the lord; but about 1680 , the distinction was laughed out of court.' ${ }^{146}$

Thus there can be no quarrel with the proposition that the courts, as well as the community at large, were cognizant of the interdependence of 
the franchise and land ownership; and the practice of creating 'occasional voters' - voters who acquired ownership of land for the sole purpose of voting for a particular candidate - was held an offence at common law early in the eighteenth century and possibly earlier. ${ }^{147}$ In addition, the practice of conveying land in order to multiply voices, or to split and divide the interest in any houses or lands among several persons, to enable them to vote at elections' was decried in 1696 under section 7 of Lord Somer's Act ${ }^{148}$ and the contract to sell votes deemed 'void and of none effect.' This prohibition was later reinforced by the institution of a not insubstantial fine in the case of contracts made in 'a fraudulent or collusive manner, on purpose to qualify' the recipient to vote. ${ }^{149}$ However, these statutes, as well as the common law criminal offence, applied only to those conveyances which were actually fraudulent, ${ }^{150}$ and the practice soon arose of splitting estates into numerous smaller units and of granting various minor interests in the same land (eg, estates for life, annuities, and rent charges), thereby creating a large number of voters whose political behaviour could be influenced by the primary landowner. Even before the Cromwellian revolution, the freehold franchise had been altered drastically; men were voting in counties in respect of annuities, tenancies for life, in tail or in fee, and rent charges, as trustees and mortgagees, and in respect of the dowers of their wives. ${ }^{151}$

Thus the mere purchase of a house with five others, all of whom were to gain votes, without a collateral contract establishing a candidate for whom the votes were to be cast, was not illegal. ${ }^{15^{2}}$ A classic case is that of Hoyland $\mathrm{v}$ Bremner, ${ }^{153}$ where a large number of properties were purchased by members of a political organization from a vendor who knew nothing of the purchasers' political intentions. The sales were affirmed without question. In Alexander v Newman ${ }^{154}$ a purchase of property for value by thirty-five purchasers from a vendor to whom the land was leased back immediately after the sale was challenged under the legislation. The vendor and purchasers held the same political views, and the admitted and sole purpose of the sale was the transfer of political identity to the purchasers. Nonetheless, the conveyances were not voided, the court holding that the legislation applied only to those alleged conveyances which did not transfer any interest in land at all, and which when made, contained stipulations as to how the franchise was to be exercised. The law reports are replete with similar cases. ${ }^{155}$ So long as the consideration for the purchase was paid, and no overt control over the exercise of the franchise was retained by the vendor, the sales were not set aside. Where, however, the purchases were infected with secret trusts - the conveyances in fact being merely fictitious - the fraudulent sales were set aside as null and void. ${ }^{15^{6}}$ 
By 1875 , Lord Coleridge could say, in a case involving a transfer of land to a trustee for the admitted purpose of enfranchising some thirty-four beneficiaries: 'It may be that the framers of this deed contemplated a fraud upon the election law. It may be that their object was to create votes. They had a perfect right to do so. ${ }^{157}$ And Archibald J, responding to the claim that the manifest intention of a transaction was to manufacture votes, said that the court would 'not look behind the legal construction of the deed. ${ }^{158}$ So widespread was the practice that in Etherington $\mathrm{v}$ Wilson, ${ }^{159}$ James $\mathrm{LJ}$ admitted: 'Of course it is familiar to us all that men constantly acquire qualifications for voting in counties. A man buys a $40 \mathrm{~s}$. freehold for the sole purpose - the undisguised purpose - of giving himself a vote in a county with which he has not and does not mean to have any connection whatever.' ${ }^{160}$ The political aspirations and motives of purchasers of land in boroughs were, it seems, even more unqualified: 'The right to vote being attached to the ownership of certain tenements, it was simply a matter of buying sufficient properties in a borough to be able to control its election." 161

The Canadian judiciary took an equally sanguine view of these practices, one case holding that under the Canadian constitutional form of government, every citizen had the right to purchase such property 'as would qualify him to vote in a parliamentary election in whatever district he pleases. ${ }^{162}$ Again, however, the purchase of votes through fraudulent sales of real property was disallowed. ${ }^{163}$

This entire drama is made all the more meaningful when one realizes that land represented not only the right to vote but also, when the franchise was extended in the nineteenth century, the power to control the exercise of one's tenants' franchise. ${ }^{164}$ The political influence which could be purchased with land could hardly be reflected or assessed in money terms:

[S]ome interesting stories were told - of a landlord in mid-Cheshire whose tenants supported a candidate during the canvass and then unaccountably voted against him; of another whose tenants asked him if they were free to vote as they wished, and on his agreeing that they were, they voted against his candidate; and the two cases that caused the greatest stir - the case of the Marquis of Lothian and the case of the hundred tenants evicted at Cardiganshire (immediately after an election) and the fund of $£_{4}, 000$ collected for them, mainly from the subscriptions of fellow tenants ...

The case of the Marquis of Lothian concerned a substantial tenant who was refused a renewal of a nineteen-year lease because he had voted against the candidate favoured by the Marquis ... Lothian said there were 'many' reasons why he had not renewed the lease, "but I should consider myself acting unfairly if I did not say out at once that among them was the vote he gave at election. ${ }^{165}$ 
Even freeholders, supposedly capable of exercising an independent mind if they could hold themselves above the pressures of social hierarchy, were amenable to economic rewards, and perhaps as tenants on other land were subject to inescapable pressure at the hands of their landlords, who might threaten them with eviction. ${ }^{166}$

This exercise of political influence through contract law, incomprehensible today, was ensured and reinforced through the practice of the open ballot, which allowed the purchaser of land to monitor the efficacy of his authority and thereby assess the 'return' on his investment. The institution of the secret ballot, although advocated for almost a century, ${ }^{167}$ did not take place until $1872,{ }^{168}$ and the exercise of overt political influence through widespread bribery at the hands of landowners did not disappear at least until then. It has been said, however, that one disconcerting effect of the secret ballot was to allow voters to take bribes from both candidates without fear of discovery. ${ }^{169}$

Finally, plural voting - the exercise of the political franchise in as many counties as one held land - was notorious. ${ }^{1{ }^{\circ}}$ While residence had been a franchise requisite for several centuries, by the eighteenth century a man could vote in each county in which he had purchased freehold land, and in 1774 the residency requirement was repealed. ${ }^{171}$ Mill wrote, 'A person may have a double vote by other means than that of tendering two votes at the same hustings; he may have a vote in each of two different constituencies: and ... this exceptional privilege at present belongs rather to superiority of means than of intelligence. ${ }^{172}$ The custom of plural voting was made possible by the practice of holding the polls open for several days, or even weeks, ${ }^{173}$ and in Canada, elections in 1867 ran from 7 August until 20 September, and in 1872 from 20 July to 12 October. ${ }^{174}$ During debates concerning Canadian electoral reform in 1885 some members argued that plural voting discriminated against those land owners who had bought scattered properties which were too distant to allow travel from one constituency to another and worked against the interest of other members who were obliged to cover the travelling expenses of non-resident voters. ${ }^{175}$ Although many abuses of the Canadian electoral process were eliminated in $1874,{ }^{176}$ remnants of this distinctly inegalitarian convention lingered until $1920 .{ }^{177}$

The ultimate consequence of the political philosophy that land merited representation in Parliament - 'the propertied basis of the franchise' ${ }^{178}$ was the general acceptance outside the structure of law of the view that the vote itself was property, to be bought and sold in the same manner as any other valuable possession. ${ }^{179}$ Consequently, any person who desired the exercise or use of this political property would have to contract for it, either in money or through barter. ${ }^{180}$ Where landed interests were in conflict, votes were traded at inflated prices; the only redeeming feature 
of such contractual freedom in circumstances of laissez-faire political competition was that the voter, if his franchise was to be purchased, at least had the choice of prospective buyers. ${ }^{181}$ It is not at all inconceivable that the price placed on land included this indeterminable, but nonetheless real, premium for the voting privileges expected by a purchaser. ${ }^{182}$ In the early eighteenth century, in the smaller constituencies, 'voting at parliamentary elections was a regular means of livelihood, ${ }^{183}$ and in view of the openness of the practice, it is not at all unlikely that the future stream of income from the franchise would constitute a not insubstantial factor in the more traditional forms of economic return from land. Votes, under this view, were marketable commodities with a fluctuating but generally appreciating value, and the only means to acquire this good was through the purchase of land. ${ }^{184}$ Traditional contract theory applied to the political relationship of the parliamentarian and his constituents reflects this view. Since the vote was a good which could be bought and sold as land, the member, if he wanted the good to be used in a certain manner, would have to compensate the owner: 'From the point of view of the electorate ... the privilege of the franchise was conceived in terms of personal advantage in the narrowest sense, ${ }^{185}$ and of course those who held land which entitled them to vote twice were doubly compensated. ${ }^{186}$

The scheme was self-perpetuating. Those who enjoyed the franchise through the purchase of land not only risked the loss of political wealth upon the dilution of their voting monopoly, but also would suffer the economic loss on the depreciation of the price paid for their votes (which presumably would be reflected in a corresponding diminution in the capital price of their land). As one commentator has observed somewhat cynically, 'the only change effected by the Reform Act was that the price of votes fell because the number willing to sell their votes had grown. ${ }^{187}$

The purchase and sale of votes, which today are distributed without regard to income or wealth, were viewed without embarrassment in earlier times. A treatise on election law published in 1880 advised solicitors, when assessing the political character of a community, to count 'men who vote only for a consideration, ${ }^{188}$ stressing that the cost of the voter was to be noted as well and warning, 'If your candidate honestly resolves not to secure these marketable votes, you must count them as against you.' ${ }^{189}$ The practice was hardly a secret one: the candidates' managers were instructed, when canvassing prospective voters, to tabulate those canvassed as: '1. Probable friendly; 2. Probable hostile; 3. Neutrals; and 4 . For sale." ${ }^{190}$

So far I have attempted to demonstrate that in England, as well as in Canada, markets and thus contracts in land were in fact private allocative devices in which the goods distributed included political identity and, 
later, political authority. ${ }^{1{ }^{1}}$ This in itself could explain the quite extraordinary contractual remedies created by the law to reflect those expectations. History demonstrates, however, that markets in land in fact represented markets in much more. Not only did one acquire political identity and influence on the purchase of land, but contracts for land were made with the knowledge that the ultimate right to hold parliamentary office was premised on land ownership. From 1711 until late in the nineteenth century parliamentary representatives from the counties and boroughs were qualified only if they possessed land worth at least $£ 600$ per year and $£ 300$ per year respectively. ${ }^{19^{2}}$ Thus the franchise and political influence were joined by a third political expectation, the privilege of sitting in Parliament, and in 1794 Clark LJ described landowners 'who alone had a right to be represented by Parliament, not the rabble who have nothing but personal property.' surprising that the legislation enacted in 1711 was described in its preamble as 'securing the freedom of parliament." 94 And of course the restriction of political power represented by ownership of land was self-perpetuating. It existed, as we have seen, for over four centuries. Land in the seventeenth century had become synonymous with freedom and liberty, an unformulated assumption upon which a vast part of the English law has been built: 'trade, law, and government itself were visualized as ministering, in different degrees, to the sanctity of landed property. ${ }^{195}$

Contract was the vehicle which society chose to allocate this political good in the same way as it had chosen contract to allocate votes. Nonetheless, Cannon notes that the requirement was evaded or 'often met by land transfers within families' or with the aid of accommodating lawyers or friends. ${ }^{196}$ It was not uncommon to discover conveyances intended to qualify the transferee to sit in Parliament or hold some other qualified elected office, ${ }^{197}$ and intra-familial transfers of property, often for a nominal consideration, were affirmed by the courts, notwithstanding that their sole intent was to enfranchise the transferor's son or to qualify him to sit in Parliament. ${ }^{198}$ Nor were contractual expectations limited to parliamentary enfranchisement or qualification, as cases respecting transfers of land to circumvent the gaming laws indicate so clearly. ${ }^{199}$ In Callaghan v Callaghan, ${ }^{200}$ however, the House of Lords dismissed an appeal from a decision of Lord Plunket refusing specific performance of an agreement to make a lease intended to qualify the transferee for a seat in Parliament, on the ground that there was no contractual intention to transfer an interest in land under the contract, but only the most obvious intention to qualify the purported lessee. ${ }^{201}$ Nonetheless, if an interest in land was to be transferred the courts would 
not hesitate to enforce contracts whose obvious intent was the purchase of status and political influence. This private right when exercised openly was protected, as one might imagine, by a property rule: an order for performance of a contract to establish the plaintiff as a baronet for $£_{5} 00$ was awarded in the early seventeenth century, ${ }^{202}$ and Maitland notes that 'no great absurdity could have resulted from the doctrine that the right to a summons [to Parliament] could be conveyed along with the lands.'203

Once we acknowledge that land rather than the individual was represented in Parliament, it becomes entirely clear that an offer of damages as compensation for breach of an agreement to transfer land would, during the eighteenth century, have been considered entirely disproportionate to the injury suffered and also an outright insult to the political aspirations of the plaintiff. Although a decision to purchase land most likely arose from a variety of motives, it may be said with some degree of confidence that monetary profit was not an overriding consideration. To the political expectations detailed above (political identity, political authority, and parliamentary qualification acquired on the sale), one may add legal expectations. Through a bargained exchange of land for money the purchaser gained entry to the narrow class of society eligible for jury service. Ownership of land was for centuries ${ }^{204}$ a qualification for jury service which, while it may or may not at one time have been a desired public duty, ${ }^{205}$ resulted in an identity of membership between political and legal communities. Men of property, that is land, were allegedly more amenable to punishment: '[T]he reason why a juryman is to have a freehold when he is sworn is that the law intends that he will more take care to speak the truth than one who has none; and if he do not say the truth he will be punished in attaint and his land wasted. ${ }^{206}$

The exercise of political and legal authority vested in the English jury was a social privilege, like so many other, which formed part of the contractual expectations of a purchaser of land. This confluence of legal institutions and land ownership was extended in 1732 to justices of the peace, who were required to possess land of at least $£_{100}$ per year ${ }^{207}-$ 'A remarkable tribute to the ideal of landed property. ${ }^{, 208}$ This legislation was, in fact, merely a revision of fifteenth-century legislation which from $144^{\circ}$ onwards demanded that every justice of the peace derive at least $£_{20}$ per year from land. ${ }^{209}$

Political identity through ownership of land and the franchise - and later, political influence exercisable over one's tenants - and parliamentary, jural, and judicial qualifications were, however, only the most tangible non-economic promissory expectations motivating the contract to purchase land. Of far greater import was the acquisition of social status. Wealth acquired through commerce or industry did not make the 
merchant or factory owner the equal of the landed gentleman - an exalted status attainable only through the purchase of an estate - and it is almost trite to say that the social status acquired with the acquisition of title to land would have defied quantification. Purchases of land were, as we have seen, often made in disregard of the financial consequences of the investment, ${ }^{210}$ and for the law to adjust the rights of the parties through a pecuniary award would have been to act in total disregard of the purchaser's social as well as his political and legal aspirations. ${ }^{211}$ Ownership of land was a social privilege - land had not, at the time, entered the stream of commerce as an economic commodity. Thus Weber writes that 'the social prestige of the manorial lords also motivates the nouveaux riches to invest their acquired wealth not in a capitalistic venture, but in land, in order to rise to the nobility if it be possible. ${ }^{.12}$ Members of the fledgling middle class who had acquired their wealth in commerce, finance, and industry bought land to attain social status 'for their children, if not for themselves.'213 The price paid for land was not simply the product of the economic wealth which it would produce for its new owner but represented the value which the purchaser, often new to wealth, would pay for entry into the landed class. Objective assessment of this value in the form of damages would have been a wholly unthinkable legal response, an insult to both parties, and a terribly imprecise and expensive task once undertaken. Social expectations and political aspirations in market transactions would have resulted in intractable difficulties in assessing the value of contractual performance, and one suspects as well that the disappointment on contractual failure would not have been compensable in money damages.

The new middle class had no shortage of wealth, while the customs and social mores of the time insisted upon land ownership as the unique badge of social acceptability: 'Traders have no bond of union, no habits of intercourse; their wives, if they care for society, want to see not the wives of other such men, but 'better people,' as they say - the wives of men certainly with land, and, if Heaven help, with titles.' ${ }^{214}$ The base financial success of the new industrialist and merchant were not the measure of social worth. If he was to make his mark he would have to 'escape from the source of his wealth, to acquire new interest, 'and he was more likely to magnify than to belittle the virtues of the life into which he and his wife yearned to be admitted, the life of wealth, of power and consideration on the land. ${ }^{215}$ It would be naive to presume that the licence to such social intercourse had a price in money, and one can quite easily appreciate the foundations of legal rules which would at once avoid valuation, affirm the primacy of land in society, and restrict whatever opportunities might have been available to transform land into an economic commodity. 
The result of all of this, as one modern writer has hypothesized ${ }^{216}$ (unaware, it seems, of his historical accuracy), was the concentration of political power in the landed classes. Entry into this exalted class could not be obtained without land; members of the new commercial and industrial classes sought to become 'squires by purchase ${ }^{\mathbf{2 1 7}}$ and, once established, attempted to entrench their status, not only through the perpetuation of legal rules which reflected political authority in economic power and which, like the doctrine of primogeniture, kept both within narrow confines $^{218}$ but also, by private arrangements, to ensure that the land which constituted a 'unique' entry to social status and political authority was retained in perpetuity by the landowner's family. ${ }^{219}$

The protection of contractual entitlements by property rules should thus be perceived as a reflection of political and social values which for centuries had identified the contract for the purchase and sale of land as an allocative device in non-economic goods - political identity and authority, legal identity, and social status. The special legal status of such contracts - enforced by the state in a manner quite unlike exchanges of commodities - recognized the non-economic expectations of the contracting parties. It seems to me, however, that the intersection of property rights in contract with political, legal, and social status should be considered as a more diffuse phenomenon. That is, the legal protection of contractual rights in land by property rules not only served to protect the expectations of purchasers; as a more general matter it reaffirmed the primacy of land ownership in English society - a primacy undeniable in terms of the cultural, political, and social perspectives of the time. The moral authority of property (land) was not extended to financial wealth, and indeed the law was structured to retain authority in those possessed of land, not money. Protection of contractual rights in land through law could engender social acceptability and consensus only if the political authority and status which the land purchaser sought was respected in legal rules defining remedies on breach. Property rules fulfilled these intentions; liability rules would only have insulted them.

There is one further point which must be examined before we turn to the analysis of liability rules in contracts for the purchase and sale of land. $M y$ thesis so far has been that bargained exchanges of real property were in reality political, legal, and social acts of extraordinary significance. That is, the contractual expectations of purchasers of real property consisted, in whole or in part, of political identity, political authority, a number of legal privileges, and social status, which may or may not have been transferred together with a valuable economic commodity. One may ask, therefore, whether an award of damages which would have enabled the disappointed purchaser to contract for another piece of land - with 
roughly similar political, cultural, and social attributes - would have constituted adequate compensation. To a limited extent that point is well taken. There are, however, several reaons for the view that such would not have been the case.

First, while equivalent economic value might have been ascertainable at a reasonable investment of legal resources, the assessment of equivalent social, political, and cultural value would have raised far more complex and unknowable considerations. It is certainly true that a sum of money sufficient to permit an alternative purchase might have provided the disappointed party with an equivalent piece of real property in economic terms. It is not as clear that the alternative real estate would have represented an equivalent 'value' in terms of social status, political identity, and political authority. A second reason for the failure of the law to develop liability rules in contract and thus to insist upon an alternative purchase of property was that the market economy had not fully enveloped the land distribution system; land was not freely available for purchase and sale. The existing distribution of economic, social, and political power leads one to conclude that only a very few would consider selling their land except if they had no other choice - to do so would, as one landowner feared, 'lower the position of my family.'220 The reasons why land was not a freely traded commodity were the amount of settled land, the moral costs of selling political authority and power, and the uncertainties surrounding the existence of the seller's right to sell. ${ }^{21}$ The disappointed purchaser's substitute contract would most likely have been shadowed by the vagaries of third-party claims to the land, and, as we shall see, the risk of loss due to a defective title was allocated by the law to the purchaser. Third, the introduction of a damage rule representing the purchaser's expectation interest would have meant that the state would be called upon to state publicly the 'worth' of political rights and social status associated with land ownership, and, as we shall see, if it is not altogether unlikely that legal rules were developed so as to avoid valuation. ${ }^{222}$ Fourth, denial of expectation damages and the prohibition, through an order for specific performance, of the right to breach contracts may have reflected an intuitive understanding on the part of the judiciary that allowing a contracting party to breach his contract and pay damages might have encouraged trade in land. The distribution of land and political power could hardly be described as equitable, and it may be that the perpetuation of this inequality was furthered by legal structures protecting contractual entitlements through property rules. ${ }^{223}$ Finally, one must note that, at least from 1696 , a breach of a contract to sell land in law disenfranchised the purchaser. ${ }^{224}$ The contractual entitlement to vote, which had been transformed in 1696 from inchoate to actual, was 
liable to be destroyed in contractual breach. It takes little imagination to consider what the social response to an attempted disenfranchisement prior to completion would have been.

Thus the relationship of legal contract remedies to political and social commodities consists of two interdependent concepts. The first, which I have described in some detail, recognizes the protection of contractual expectations of political, legal, and social status by property rules. The second facet of the symbiotic relationship between culture and law was the legal decision not to protect these same non-economic expectations by liability rules. The duality of the thesis recognizes that contractual remedies generally afford individuals the freedom to choose which of damages or specific performance better maximizes their individual satisfaction. In the case of exchanges of political, legal, and social status, however, the state insisted that contractual expectations, if they were to be recognized at all, were to be protected only by a property rule. It is impossible to say with any degree of certainty why liability rules (damage awards) did not develop to any substantial degree in respect of contracts to sell land. Yet the matter deserves investigation. A decision to protect contractual entitlements by property rules does not necessarily deny the existence of liability rules under some circumstances for a breach of an agreement to exchange political, legal, and social status for money; and theories of individuality and wealth maximization would suggest that both kinds of entitlement would have been recognized in law. The evolution of the law in this context to deny damages reveals attitudes which reinforce the view that political, social, and legal contractual expectations provided the foundation for the development of property in contract.

The legal rules denying recovery of damages in respect of contracts for the purchase and sale of land are well known. Courts exercising equitable jurisdiction to order performance of contractual obligations were not granted express authority to award damages until $1858,{ }^{225}$ and since disappointed purchasers would generally have sought equitable relief their primary interest being land rather than economic wealth in the guise of money damages to which they may or may not have been entitled principles of damage remedies in respect of land contracts remained in the most attenuated forms until the latter part of the nineteenth century ${ }^{226}$ Of course a court could, in awarding specific performance of a contract, concurrently order that the price be modified in an amount equal to the reduced value of the property transferred, ${ }^{227}$ this compensation (even though it involved valuation of that part of the contract left unperformed) being 'very different' from damages. ${ }^{228}$ It is only fair to say that money awards had been ordered, albeit infrequently, in Equity, ${ }^{229}$ 
but this was without statutory authority and notwithstanding Lord Eldon's admonition that he was 'not ... aware that this Court would give relief in the shape of damages. ${ }^{230}$ Nonetheless, it has been argued that where the failing was one of tenure, the vendor would not likely obtain specific performance together with compensation. 'Differences of tenure do not in general admit of valuation, ${ }^{231}$ and because tenure was the criterion upon which the franchise was founded, monetization of political rights and social status in Equity would not generally have been the practice.

The disinclination of Equity to assess the value of contractual expectations to land was adopted, as well, in the common law courts, which would not, in the usual case, award damages (contrasted with an order for the return of the purchaser's deposit and incidental expenses) on a basis which would oblige the courts to embark on the treacherous task of assessing the value of real estate. The leading case of the eighteenth century, Flureau v Thornhill, ${ }^{232}$ denied recovery for the loss of the 'fancied goodness' of the purchaser's bargain, a limitation which was affirmed with unwavering consistency throughout the nineteenth century. ${ }^{233}$ Earlier cases, which are hardly well known, reveal very little of the forces operating on the law at the time. ${ }^{234}$ Gray $\vee$ Briscoe, ${ }^{235}$ decided in 1604 , involved an executed contract and a conveyance of land by the defendant of which he said he was seized in fee simple. In fact, he held only by copyhold. The somewhat cryptic report states that 'the jury shall give damages, in their consciences, according to that rate, that the country values fee-simple land, more than copyhold land. ${ }^{, 236}$

The best-known example of the comon law rule forbidding recovery of lost profits, first enunciated in 1775 in Flureau v Thormhill, ${ }^{237}$ is the decision of the House of Lords in Bain v Fothergill ${ }^{28}{ }^{8}$ to restrict contractual recovery in land contracts which failed because of a defect in title to return of the purchaser's deposit with interest and incidental expenses. ${ }^{239}$ Lost profits the value of the purchaser's bargain - were not recoverable. Traditional explanations for the rule range from an implied contractual term denying recovery of the purchaser's expectation interest in the light of the widely known inaccuracies of the land registration system in force in England in the eighteenth and nineteenth centuries; ${ }^{24}{ }^{\circ}$ judicial legislation designed to increase the liquidity of realty; $;^{241}$ and contractual liability premised on fault rather than strict liability. ${ }^{24^{2}}$ In addition, it has been argued -indeed the point was made in Bain $\mathrm{v}$ Fothergill itself - that the expense and time concomitant to assessment of real estate values justified a decision which rendered the calculation of damages certain. ${ }^{243}$ Related to this theory is another which explains the rule in Bain v Fothergill as a judicial device designed to limit the disconcerting practice of juries of awarding arbitrary 
and sometimes outrageous damage awards, exacerbated by the absence of objective evidence of value. ${ }^{244}$ Mayne offers a more enlightened view, suggesting that the rule forbidding recovery of the appreciated value of the land in the case of executed contracts 'is clearly the equitable rule, where the improvements arise from causes of an entirely collateral nature, such as the growth of a town, the formation of a railway, or the like. The occupier has had all the benefits of this increased value, so long as it lasted, without paying anything like it. ${ }^{245}$

It is true that doctrinal purity and administrative convenience must be recognized as having played a role in the evolution of laws which denied protection of contractual entitlements by liability rules. My point, however, is that the societal decision to deny the right to recover damages was based upon considerations identical to those which provided the foundation for the recognition of property rights in contract. It may be argued that motives very different from those expressed in the cases lay behind the common law doctrine denying recovery of damages for breach of contract to sell land. The combined forces of the rules mandating performance of land contracts almost without exception and complementary rules denying compensation in damages defined land, and contracts respecting land, very differently from other kinds of property and contracts.

Specific performance as a means of withdrawing land from commerce, or, in any event, of erecting barriers to its entry, may be perceived more accurately as a component in a broader political constitution which included a common law rule denying recovery of lost profits on breach of a contract to buy land. Fuller and Perdue have detailed the significance of recovery for lost opportunities, or, to put it differently, of recovery of an individual's expectation interest, as an incentive to the development of market exchange transactions in western economies:

In seeking justification for the rule granting the value of the expectancy there is no need, however, to restrict ourselves by the assumption, hitherto made, that the rule can only be intended to cure or prevent the losses caused by reliance ... It may be said that there is not only a policy in favor of preventing and undoing the harms resulting from reliance, but also a policy in favor of promoting and facilitating reliance on business agreements. Agreements can accomplish little, either for their makers or for society, unless they are made the basis for action. When business agreements are not only made but are also acted on, the division of labor is facilitated, goods find their way to the places where they are most needed, and economic activity is generally stimulated. These advantages would be threatened by any rule which limited legal protection to the reliance interest. Such a rule would in practice tend to discourage reliance. The difficulties in proving reliance 
and subjecting it to pecuniary measurement are such that the business man knowing, or sensing, that these obstacles stood in the way of judicial relief would hesitate to rely on a promise in any case where the legal sanction was of significance to him. To encourage reliance we must therefore dispense with its proof. For this reason it has been found wise to make recovery on a promise independent of reliance, both in the sense that in some cases the promise is enforced though not relied on (as in the bilateral business agreement) and in the sense that recovery is not limited to the detriment incurred in reliance. ${ }^{246}$

Generally, we have chosen to encourage commerce through legal recognition of the purchaser's expected return on his investment - a legal rule complemented as it must be (in terms of economic efficiency) by a general rule denying specific performance. The operation of the two rules allows a promisor to break his contract whenever it is advantageous for him to do so while at the same time leaving the promisee no worse off, in monetary terms, than he was prior to the breach.

Land, however, was not accorded such a liberal ideology. Specific performance tied the hands of sellers of land who might otherwise have breached their contracts if offered a higher price by one to whom the land was more valuable. ${ }^{247}$ In addition, the most potent form of incentive to contract - legal protection of the contractor's expected economic profit was, in a very great number of cases, denied outright. The most obvious and substantial risk in the market-place in land (ie, the risk of nonperformance due to a defect of title) was allocated by the state to the purchaser. He might, of course, negotiate for a reallocation of that risk to the seller, but the transfer would not come cheaply, and negotiations are never costless. Finally, the risk was absolute. Not only was the loss non-compensable in damages, specific performance would not generally be ordered if the seller did not have full ownership of the land ${ }^{248}$ Without this encouragement, markets in land in the hope of attaining financial profit may not have developed as rapidly as they otherwise might have.

One cannot but question the foundation of contract when, for some two hundred years during which specific performance was granted almost without hesitation, one can uncover perhaps three or four cases in which damages for breach were sought, ${ }^{249}$ compared with dozens of reported cases in contracts involving goods. ${ }^{20}$ Perhaps a modern perspective allows a more sensitive appreciation of the subtle impact of denying recovery for lost profits: '[R]eal property is the only character of property absolutely essential to human existence, and ... it is the policy of the law ... not to encourage speculative or chance bargaining in it, but to adjust the rights of the parties concerning its transfer, by placing them in the status quo. ${ }^{25^{1}}$ The status quo is precisely what contract and exchange relation- 
ships are not about, and in societies in which land was not so intensely endowed with political and social personality, calls for the abolition of the rule and for legal recognition of the expectation interest in contract came quickly. ${ }^{252}$

It is a truism to say that the power to alienate is a central element in the bundle of rights which constitute 'ownership' in land, and while society acknowledged the right to transfer land through private bargains, barriers were erected through which contractual exchange could take place only with substantial interference. It has been said, for example, that the medieval distinction between real and personal property amounted 'roughly to this, that over the first, one had much less power of disposition than over the second. ${ }^{253}$ Primogeniture, ${ }^{254}$ the perpetuation of feudal tenures until $1660,{ }^{255}$ and the pervasive resistance to land reform which would have increased security of titles and eliminated the worst part of the consumptive costs on land transfer ${ }^{256}$ are only the most obvious devices which limited economic intercourse in land. To these can be added specific performance. Unlike the law applicable to all other contracts, which simply meant that a party who intended to breach would have to assess his prospective profits on breach against the damages payable to his first contractor, the law of specific performance, through the creation of a property right in the purchaser, forbad the sale of land at a better price to an alternative purchaser who valued the property more highly, unless the first purchaser were willing to sell his opportunity to engage in political life and society. In addition, the purchaser of land could not generally recover his expectation interest or profit on breach, and in an era when ownership of land was notoriously obscure and inconclusive the risk of non-compensable forgone opportunities arising on contractual failure operated as a potent disincentive to contractual exchange. Finally, the costs of professional assistance, registration fees, transaction taxes, expenses of searching and confirming title, and the substantial delays characteristic of land transfer in the eighteenth and nineteenth centuries combined to create imposing obstacles to efficient market exchange. The existence of these 'costs of sale,' added to the cost of the land itself, would certainly have reduced the incidence of exchange transactions. As transaction costs are added to the 'true market value' of the land, the number of willing buyers diminishes, and the most probable transactions (between buyers and sellers of land whose numbers are, by definition, highest at the market price) are excluded. ${ }^{257}$

The point here is quite simple. The rule denying compensation in damages for a breach of contract to transfer land, if in reality a contract to transfer political, legal, and social status, may have operated as a barrier to the creation of markets in land - and may thus have protected and 
reinforced the existing distribution of those commodities. In addition, rules denying compensation may have had a more subtle, but equally significant, impact on the manner in which society and the law defined land and thus exchanges of land.

I remarked earlier, too summarily perhaps, that liability rules in contract presuppose that society is willing to engage in the public valuation of the object of private exchange relationships. When we enforce contracts to transfer grain, or automobiles, or corporate shares, we do not find it disturbing (if in fact the issue enters our conscious minds at all) that a public, government agency (ie, a court, and in particular a judge whose orders are enforced through executive action) will tell us what these commodities are 'worth' in dollars and cents. This dispassionate attitude to public valuation is not always so easily come by. Were a judge to enforce a contract to sell a kidney, or an arm, or a leg, some of us, at least, would react with horror. While markets in many goods have been permitted in western societies, markets in human body parts have not gained considerable social acceptance. Although some might actually insist that everything has a price, ${ }^{25}$ and while economic analysis of contract remedies has implicitly assumed monetization of all losses, ${ }^{259}$ that assertion, even if true, does not necessarily mean that the state should announce that fact, and indeed it does not deny that some want to believe that certain things are (or perhaps ought to be) literally priceless. The point is that the pricing of certain 'ethical phenomena' ${ }^{260}$ carries the risk of degradation if in fact such monetization is possible at all, and at its most simplistic level the costs of this monetization may be so great as to justify the adoption of distribution and allocative mechanisms other than the market. As we have seen, land transfer was a political and cultural ceremony of some significance, and while society may have allowed market exchanges in land to take place, the bargaining was not always an amoral event. 'Is it going too far to suggest that while estates in land were focused with a vital personal affinity between lord and vassal, to speak of a land market [was] profane?'261

Thus we have seen that while contracts for the sale of land, which as a matter of course carried the franchise and political authority, were specifically enforced, the law denied legal recognition of contracts which were openly bargains to distribute votes or to confer a knighthood. The point here is that the law may have been unwilling to admit that social goods were being traded like all other commodities. We put prices on things we don't want to price, but we don't like doing it, admitting that we do it, or especially having it called to our attention. We enforce contracts knowing the buyer is buying the right to sit in Parliament, but if he says he is doing that we call him 'venal' or 'mercenary. ${ }^{262}$ This would be even 
more so if we as a society were asked to state publicly the worth of that right. Essentially the same attitudes were revealed by one commentator who wrote, at the turn of the century: 'There was a time, and that not many years since, when a proposal to a landowner to discuss the merits of what is called "Free Trade in Land" would have been regarded by him in much the same light as a suggestion that he should put a price on his personal raiment. ${ }^{263}$

The political and social goods associated with land ownership may have evoked powerful moral notions as to the appropriate role of the state in recognizing market transactions. At the same time, this almost religious sanctity may have been raised as justification for the decidedly skewed distribution of land in society. The inequalities of distribution were, as Mill put it, justified by imbuing land with honorific qualities: 'Landed property is felt even by those most tendacious of its rights, to be a very different thing from other property; and where the bulk of the community have been disinherited of their share of it, and it has become the exclusive attribute of a small minority, men have generally tried to reconcile it, at least in theory, to their sense of justice, by endeavouring to attach duties to it, and erecting it into a sort of magistry, either moral or legal. ${ }^{, 264}$

Calabresi and Bobbit have denominated this market trait as the 'cost of costing': ' $[\mathrm{M}]$ oralisms and the affront to values ... of market determinations that say or imply that the value of life or some precious activity integral to life is reducible to a money figure. ${ }^{2{ }^{26} 5_{5}}$ The 'right' to land created through the adoption of property rules during the seventeenth and eighteenth centuries emphasized the pricelessness of land through obviation of the odious task of public assessment of the value of so majestic a good. Political authority, the right to vote, and social status (all represented by promissory entitlements to land) were protected, to a very large degree, by a property rule and not by a liability rule. ${ }^{266}$ Not only did society through specific performance acknowledge the primacy of land; at the same time it retreated from calls to engage in the pricing or monetization of social class or political power.

The conclusion one must draw after assessing the development of property rules and liability rules in contracts for the transfer of land is that the law not surprisingly reflected the very powerful political and social mores of the times. The limitations on freedom to contract created and preserved through the technical complexities of the land law were complemented both by the denial of the freedom to breach through the doctrine of specific performance and by the denial of compensation if breach did occur. Land was not destined to become a commodity trading freely at prices determined by multitudes of individual bargains. Rather, as a proxy for political authority, it would be kept within narrow bounds, 
perpetuating a social hierarchy where 'the freeholder on the land, and the freeman in the town were, each in his sphere, the accredited elements in society, in comparison with which other men appeared, not as rival classes, but as adjuncts, or excrescences, or even social dangers. ${ }^{267}$

Economic individualism and the metamorphosis of the legal and economic foundations of English society from status to contract ${ }^{268}$ were not to alter the status of landlord. Pollock, in his notes to Maine's treatise, says '[W] hat we call [a man's] status is his position as a lawful man, a voter, and so forth, ${ }^{, 269}$ implicitly acknowledging that the transfer of freehold land would have consisted of an exchange of money for political status. And the metamorphosis of land from a symbol of political and social status to an economic commodity would have meant the devolution of political authority to all of those who could pay for it. The sale of land, if assimilated to the sale of personality, would have become a commercial event involving the exchange of wealth in money for wealth in land which would have meant the death of the sale and contract as a political and social event. Specific performance and non-recovery of damages were simply doctrinal manifestations of values which had evolved in a society which first created a right to participate in government, then defined it in terms of the ownership and possession of a real object in the hands of a relatively narrow structure of society, and finally established and preserved legal rules which at once proclaimed the ideal of representative democracy and the inviolability of property.$^{270}$ Land, during the early history of England, does not easily fit within the paradigm of contract as linked to the ethics of free enterprise, small individualistic entrepreneurs, and capitalism. ${ }^{271}$ To the extent that free enterprise capitalism existed at all, it did not apply to the ownership of rights enjoyed by a narrow political élite. The state had a direct and abiding interest in the distribution of this political wealth among the populace, and if freedom of contract would entail a reallocation of political authority, those who controlled the machinery of government, including judicial government, would not be likely to encourage it.. ${ }^{272}$

The absence, or at least the sublimation, of pecuniary motivations in transactions which assumed the guise of contract but in substance were consumated with radically different objectives nurtured the advancement of non-pecuniary remedies. Personal expectations of political identity or societal objectives respecting the allocation and transfer of land would hardly have been well served had legal institutions limited redress to money compensation. The observation that 'the factors that have made compulsion of promisors attractive in a planned economy are plainly absent in a free enterprise economy ${ }^{\prime 273}$ takes on a special meaning in the light of the role of land before the industrial revolution. Land had not yet been incorporated into the market-place, and the 'privileged freeholder' 
who clung to his vote with extraordinary tenacity, secluding it from copyholders and leaseholders, did so by keeping his freehold out of the market. In the end, this tactic could not have met with success, and indeed landowners were mortgaging and selling off their land throughout the seventeenth and eighteenth centuries in order to raise capital. But they did so only because they were left no alternative, and they did it with a full knowledge that society would thereby be admitted to the franchise. ${ }^{274}$

The status of land and, for our purposes, the status of contracts to transfer land that is reflected in the evolution of property rules and the complementary modification of liability rules denying recovery of expectation interests has surfaced in at least one jurisdiction, in the application of criminal sanctions to interference with promissory entitlements. This extension of protection beyond liability and property rules reflects a philosophy of state compulsion not frequently found in the common law of contract. ${ }^{275}$ The introduction of penal sanctions to enforce contracts or to deter purposeful contractual breach is most obvious in the context of imprisonment for contempt, exercisable against a promisor whose voluntary private obligation has been transmuted into law through the issuance of an order for specific performance. His incentive to perform, perhaps consisting of the fear of social reprobation, the loss of commercial reputation, or an order to pay damages, is joined by the prospect of incarceration for contempt. Less common is the application of direct criminal liability for breach of contract such as existed in respect of land contracts even in Canada. ${ }^{276}$

Generally, the law has not coerced men to keep their promises, except in so far as recovery for lost profits is perceived as a penalty designed to encourage reliance on contract. ${ }^{277}$ It is just possible that the direct imposition of criminal sanctions for breach of consensual obligations $\mathrm{s}^{278}$ to transfer land and the more common indirect invocation of penal sanctions through the threat of contempt in the case of an order of specific performance evince a sensitivity not only to the expectations of purchasers of land apart from their purely financial motives but also to the social philosophy that land was not an economic commodity liable to be debased by market bargaining and distributed according to taste among the common populace. Rather, as we have seen, land was retained as a symbol of social class - its ownership a measure of political authority - and thus its distribution among the citizenry was to be closely monitored. ${ }^{279}$

Epilogue

In view of the overt political and social nature of land ownership, it is not at all surprising that the contracts to exchange land dramatized the 
creation of property rules to protect contractual entitlements. Enfranchisement on the acquisition of title could be made the object of a compensatory damage award only in a most superficial manner, with substantial risks of error, and only after a significant expenditure of judicial resources. The 'fancied goodness' of one's bargain on the purchase of real estate not only consisted of the obvious economic worth of the land (even if one could assess and account for the present value of future electoral payments) but included as well the enormous political power represented by the vote itself - in some cases the licence to sit in Parliament - and the incalculable value of political authority which the landowner could exercise over his tenants. At a time when the common law was moving towards objective valuation of compensation in cases of contract damages, ${ }^{280}$ the inescapable subjectivity and affront to social values represented by an attempt to value political rights and social privilege inevitably foreclosed the application of liability rules to contract entitlements in respect of land. While there is little doubt that other attributes of such contracts distinguished them from exchange transactions to which liability rules were traditionally applied, ${ }^{281}$ the social status and the value of political authority which surrounded the acquisition of land in England before the nineteenth century certainly played a role in the creation of law.

But all of this is history. Ownership of land no longer constitutes a legal prerequisite to vote, to sit in Parliament, or to act as a juror. ${ }^{282}$ Landowners no longer control the exercise of their tenants' franchise, nor do tenants charge for their support. Egalitarianism, at least in the context of electoral democracy, is relatively well established in our political culture. And while class still pervades social intercourse, land ownership is hardly a unique badge of social acceptability.

Where, one might ask, do we go from here? If, in reality, political, legal, and social status are more evenly shared in Canada than was the case in England during the seventeenth and eighteenth centuries (or perhaps ought to be more evenly shared), what can one say about the law? The answer has two parts. The first is that the legal rules relating to contracts for the transfer of land may not be as absolute as once believed. Property rules may be applied in a discretionary manner, and liability rules may be recognized without fear of encouraging commerce or of degrading political and social class. The second part of the answer is that the legal rules defining rather different contracts which may now be associated with political and social identity may be evolving in a manner which reflects that underlying cultural reality. I have described the weakening of the traditional property rules protecting contractual entitlements to land $^{283}$ and the complementary modification of the liability rules which 
historically denied protection to those contractual entitlements. What I would like to do now is to explore the implications of this thesis in respect of contracts involving the exchange of labour for money.

It may be argued that the evolution of political, social, and cultural mores that has provided the foundation for the tentative, though dilatory, metamorphosis of contractual entitlements in respect of land may at the same time provide some insight into the legal definition of labour entitlements. Legal principles respecting promissory entitlements under individual and collective contracts of employment over the past century have reflected a persistent progression from liability rules to property rules, and courts no longer order the specific performance of contracts respecting land in every case. ${ }^{284}$ This redefinition of the nature of contractual entitlements to which the law applies property rules is hardly startling, and the institution of labour which most often surfaces when contract expectations are specificially enforced in a modern context has, to a large extent, joined land as a source of political and social authority. The boundaries of political and social power are now exceedingly diffuse. The distribution of political and social power is no longer as narrow as it once was, and the boundaries of property rules in contract cannot but reflect that dissipation. ${ }^{285}$

Historically, contracts of employment were not afforded the status of property, the common law rule stating emphatically that if a contract is terminated there are ordinarily no questions affecting status or involving property rights. ${ }^{286}$ The ostensible foundations for the rule - a supposed fear of coerced employment and an understandable reluctance to oblige individuals to work in a close personal relationship with one another - are well known. ${ }^{287}$ One cannot, however, ignore the reality of protecting employment contracts by liability rules. As soon as society allows an individual to interfere with another's contract entitlements and simply obligates the contract-breacher to pay damages to compensate the other for his economic loss, ${ }^{288}$ we sanction industrial decisions of the employer made solely in his interest. That is, where we decide not to protect a contractual entitlement to employment by a property rule, all the gains generated by the employer's breach are retained by the employer. At the same time we ignore the non-economic attributes of the contract of employment which, depending on one's philosophy, are non-compensable in money damages, ought not to be compensable in damages, or are compensable only after extensive judicial assessment of intangible loss and the concomitant risk of over-compensation or under-compensation.

It is not at all surprising that liability rules in the case of contracts of employment have undergone substantial modification in response to the transformation in the nature of the employment relationship and in the 
expectations and attitudes of members of society towards employment. A person's job is no longer simply a means of acquiring short-term financial gain. It often represents security in the form of pension and seniority rights, status in the form of community respect and recognition, a sense of camaraderie with one's fellow employees, political influence through union membership, a foundation for marital and familial stability, security in an increasingly transient work force, a position of authority in a union hierarchy, and much more. What we have seen in response to these non-economic attributes of contracts is a judicial acceptance of the philosophy that losses suffered on breach of an individual contract of employment are of more than a narrow financial import to an employee. The resulting modification of the rules defining labour entitlements has had two branches. The first has been the recognition of subjective, non-economic expectations in the application of liability rules. The second has been the protection of labour entitlements by property rules.

The older cases almost unanimously rejected claims for non-economic loss on breach of contracts of employment, ${ }^{289}$ and those which did acknowledge this facet of contract allowed recovery for other than lost wages only in cases of theatrical or journalistic endeavours, ${ }^{29 \circ}$ on the theory that a term of the contract of employment, express or implied, was the opportunity of enhancing the employee's reputation. ${ }^{291}$ The intransigent attitudes expressed at the turn of the twentieth century in Addis v Gramophone Company Ltd. ${ }^{29^{2}}$ which it has been said by one judge 'can work injustice," ${ }^{, 93}$ have in recent times been adopted with reluctance. In Cox v Philips Industries Ltd. ${ }^{294}$ Lawson, J awarded $\AA_{500}$ to the plaintiff, representing the 'vexation, distress and general disappointment and frustration' ${ }^{\prime 25}$ consequent upon the loss of employment. In another case, the 'loss of social prestige' incurred by union members who had been wrongfully expelled from their union was held compensable in contract, notwithstanding the absence of any demonstrable pecuniary loss. ${ }^{296}$

Moreover, the extension of the interests protected by liability rules in the case of contracts of employment has been complemented by modifications of the principles of specific performance. While it is too early to say whether or not an individual can be considered to enjoy the 'ownership of his job,' an increasingly sensitive judiciary and legislature are responding to the realities of social and economic life in the twentieth century. No longer can we accept the absolute authority of the law of master and servant reflected in judicial attitudes of the nineteenth century: 'A servant is a person subject to the command of his master as to the manner in which he shall do his work.' ${ }^{297}$ Although there may still be legitimate fears of economic duress in cases of employers seeking to enforce labour contracts, ${ }^{298}$ rules prohibiting the specific enforcements of labour con- 
tracts are no longer absolute. The personal element of contract and the archaic status relationship of master-servant have in a very great number of cases become a fiction. In addition, the creation of the limited corporation and the reallocation of bargaining power through the legitimation of collective labour action suggest that historic fears of villeinage are no longer incontrovertible, if in fact such fears ever existed.

Traditional contract theory has justified the application of liability rules to labour entitlements on the theory that the establishment of property rules - that is, specific performance of labour contracts - would have transformed agreements to serve into private enslavement at the behest of the employer. Thus the employer's entitlement could not be protected by a property rule, and theories of mutuality ${ }^{299}$ were invoked to justify the converse - neither could the employee's entitlement be protected by a property rule. The thesis which I have developed in relation to land - that property rules were designed as a constraint on market exchanges and as a societal response to non-economic attributes of certain exchange relationships - suggests that rather different motives may explain the creation of labour entitlements which at the hands of the employee were protected only by a liability rule, while at the hands of the employer they were protected not by a private property rule (specific performance) but rather by a public property rule - the criminal law.

As we have been told so often, employees as well as employers were free to break their promises subject only to liability in damages. If the employee was offered better wages, or if the employer could take advantage of less expensive labour, each was free to act as he wanted. This liberal ideology was, however, more apparent than real. Evidence suggests that, in reality, employers could very often 'specifically enforce' contracts of employment under the criminal law, while employees did not enjoy a complementary property right. Legal coercion can operate either through the vehicle of specific performance or, more directly, through the application of criminal sanctions for breach of contractual obligations. While specific performance was denied on the grounds that the law would not compel personal servitude, the criminal law for centuries described a breach of a contract of employment as a crime.

From $166_{3}$ onwards, justices of the peace were granted jurisdiction to resolve employment disputes (to use a modern phrase) in certain cases, mostly involving payment of wages. ${ }^{300}$ Any person trained in any of a wide variety of specific crafts was compellable to work in that craft except if the person was possessed of lands, tenements, or for a term of any life or lives of clear yearly value of forty shillings (thus exempting land owners from the application of the statute!), and servants who departed from their master's service ('who promise or covenant to serve and do not serve 
according to the tenor of the same') ${ }^{301}$ were subject to be committed 'to ward, there to remain without bail or mainprise' until they would agree to return and serve their master according to law. ${ }^{302}$ In addition, servants who left the jurisdiction where they were employed were subject to recapture and imprisonment until they found another 'well and honestly to serve their masters ... according to the order of the law. ${ }^{303}$ Dissatisfaction with the act led to its replacement in 1747 by more extensive regulatory legislation. ${ }^{304}$ Any employee within statutorily prescribed classes who was found guilty of any misdemeanour, miscarriage, or ill behaviour in his or her service or employment was subject 'to commitment to the house of correction, to remain and be corrected [whipped] ${ }^{305}$ and held to hard labour for a reasonable time, not exceeding one calendar month. ${ }^{306}$ In 1766 , further legislation was enacted in response to the disturbing practice of apprentices who, after considerable training at substantial cost to their masters, left for better wages. ${ }^{307}$ After 1766 such behaviour in breach of contract was punishable by up to three months' imprisonment. ${ }^{308}$ In addition, section 4 of the act applied to servants and employees 'who contract with persons for certain terms, [and] leave their respective services before the terms of their contracts are fulfilled, to the great disappointment and loss of the persons with whom they so contract.' The remedy for breach of contract under that section was imprisonment for up to three months and not less than one month. ${ }^{309}$ There can be no doubt that this legislative framework, which remained in force for the greater part of the nineteenth century, ${ }^{310}$ imposed criminal liability for breach of an employment contract by an employee. Mens rea was a necessary ingredient of the offence, ${ }^{311}$ and, as we have seen, the penalties for breach of contract were severe.

Thus we can see that employers did not need to seek the assistance of the state in the guise of enforcing entitlements by property rules. Far more expeditious and effective redress was available through the coercive medium of the criminal law. The liberal rhetoric of the Equity judges was, it seems, a facade, a distortion of real societal values which compelled the performance of personal service contracts through corporal punishment and incarceration. The remote possibility of imprisonment for contempt of court in the case of a refusal to obey an order for specific performance would evoke little fear in a servant liable, in summary proceedings, to imprisonment or physical brutality.

In any event, labour relations have now moved to a point very distant from the quasi-servitude characteristic of the eighteenth- and nineteenth-century employment relationship. The modern example of contractual breach in the sphere of employment relations consists of an arbitrary dismissal of an employee contrary to the terms of a collective 
agreement prohibiting discharge except for 'just cause.' When an employee is discharged in violation of the terms of a collective agreement, his only 'right' to continued employment is a contractual right either under an individual contract of employment or, more commonly, through the medium of a collective agreement of which the individual employee is a beneficiary. Traditional contract theory tells us that the employee's entitlement under his contract consists only of a right in damages. Modern labour policy is another matter entirely. A breach by an employer where the collective agreement prohibits discharge except for just cause is remedied in arbitration proceedings not simply by an order for payment of money damages but in addition through a mandatory order that the employee be rehired: "Although an order of reinstatement and the substitution of a lesser penalty generally involve a form of mandatory order that was not recognized at common law, the authority of an arbitrator to reinstate an employee who was unjustly discharged has never been questioned. ${ }^{312}$

The same philosophy has been reflected in court decisions through relaxation of the principles which historically denied the rights of employees to the specific enforcement of individual contracts of employment. Individual contract entitlements have been protected by property rules when the terms of a collective agreement provide expressly for continuation of the employment relationship, and injunctive relief restraining an employee from engaging in his occupation has been ordered by the court, at least for a temporary period.$^{313}$ As long ago as 1944, the province of Saskatchewan enacted The Trade Union Act, ${ }^{314}$ which authorized an administrative tribunal, inter alia, to order an employer to reinstate an employee discharged in violation of the provisions of the act. The contrast between this view of labour contracts and traditional judicial conservatism was explained by the Judicial Committee of the Privy Council in Labour Relations Board (Saskatchewan) $\mathbf{v}$ John East Iron Works:

The jurisdiction of the Board under s.5(e) is not invoked by the employee for the enforcement of his contractual rights: those, whatever they may be, he can assert elsewhere. But his reinstatement, which the terms of his contract of employment might not by themselves justify, is the means by which labour practices regarded as unfair are frustrated and the policy of collective bargaining as a road to industrial peace is secured. It is in the light of this new conception of industrial relations that the question to be determined by the Board must be viewed, and, even if the issue so raised can be regarded as a justifiable one, it finds no analogy in those issues which were familiar to the Courts of $1867 .^{315}$

In more recent times, the Canada Labour Code ${ }^{326}$ has established a right, 
albeit in limited circumstances, to reinstatement of employment when an employee has been unjustly dismissed.

Collective rights enjoyed by the trade union and individual employees and the complementary contractual right of the employer to collective labour, established under collective agreements, are also protected by property rules. A lockout occurring while a collective agreement is extant is remedied not by damages but rather by injunctive relief. ${ }^{317}$ Similarly, an illegal strike will be enjoined, a distinction being drawn between the institution of forced labour and the enforcement of modern collective agreements. ${ }^{18}$ The reasons for the transformation of the contractual entitlement are obvious. Obedience to the provisions of the collective agreement is often crucial to economic stability, the collective employment relationship involving thousands of employees in industries interference with whose operations would inevitably cripple vast sectors of a sensitively balanced and interdependent economy. Industrial peace, not industrial strife compensated by damage payments, has become the judicial and legislative goal. Expectations under collective labour contracts, from the perspective of both the employee and the employer, have replaced entitlements created by the seventeenth-century contract for the sale of land as deserving of protection by property rules. The collective agreement, however, has an economic impact which reinforces the social and political influence which it now reflects. In fact, the economic consequences of a major industrial dispute may be so terribly devastating to individual employees and employers, as well as to the economy of the nation, that the time-honoured but abstruse phrase that 'damages are an inadequate remedy' once again becomes meaningful.

The concept of 'ownership of jobs,' which simply reflects the enforcement of promissory entitlements through property rules, is now a common social expectation:

With respect to the protection of the employee's interest in his job, we are dealing with an inference from facts rather than with a judicially named property interest. The legal recognition of collective bargaining as a 'right' with workers maintaining their employee status during strikes or other labor disputes, and with enforceable claims on employment if illegally discharged, with back pay for the period of illegal withholding of employment - all this amounts to property, however unwilling the courts may be to offend traditional sentiment by use of the term..$^{319}$

Perhaps the form of property in employment which readers will recognize most immediately is that defined by membership rights granted by self-governing professional licensing institutions. Membership in the medical, legal, and academic professions, or indeed in any other private organization which exercises a monopoly or near-monopoly over a 
unique and essential service and which restricts entry through any of a variety of standards, is an 'immensely valuable right, ${ }^{320}$ representing a legal licence to perform certain activities which others are excluded from performing. ${ }^{321}$ The 'right' to join a profession or to continue one's membership if one has fulfilled the professional requirements ${ }^{322}$ and has not breached the rules established by the guild is protected by a property rule. Thurman Arnold once described himself as owning only 'rank and privilege in an organizational hierarchy, ${ }^{, 23}$ and many of us today could say little more than that. Charles Reich echoed these sentiments three decades later, when he spoke of wealth deriving from professional or occupational employment. ${ }^{324}$ Reich called attention to the failure of society to afford substantive and procedural protection to these new forms of property, a failure remedied today in some jurisdictions by judicial creativity, legislative initiatives, and executive programs. ${ }^{325}$ The most dramatic example of this metamorphosis in contract entitlements in respect of labour contracts is the institutionalization of specific performance of employment contracts in England. There, legislation has emphasized reinstatement and re-engagement of employees, which became primary remedies in cases of individual loss of employment under the Employment Protection Act, $1975^{326}$ and have been continued in more recent times under the Employment Protection (Consolidation) Act, $1978 .^{327}$ Yet the legislation, which in a euphemistic trick has avoided using the term 'specific performance' to describe its remedial process, does not sanction disobedience through the invocation of judicial or administrative contempt. Instead it authorizes economic sanctions ${ }^{328}$ - the assessment of substantial sums above the amount considered appropriate according to compensatory standards. ${ }^{329}$

This tentative advance in the law, in respect of both individual and collective contract entitlements, merely reflects another stage in a long history of social innovation designed to promote the creation and redistribution of property and, with it, the transfer of social and political power. Legislation which first relaxed and then erased franchise qualifications premised on land ownership was interwoven with and dependent upon the introduction of reform legislation designed to simplify the archaic, irrational, and wholly dysfunctional land law, which, in governing the ownership and sale of land, had effectively precluded access to it. Simplification of substantive real property $\operatorname{law}^{330}$ and the introduction of legislation which insisted upon public registration to protect property rights $^{331}$ intended to reduce the fetters on land as a factor in commerce were but an adjunct of political reform. The revolution in democratic politics and land ownership went hand in hand, and efforts to subvert reform were directed at both. Dicey, reflecting on the conflict in 
philosophies of democratic socialism and radicalism in the nineteenth century in their efforts to 'make land easily saleable' ${ }^{322}$ when confronted both by the political conservatism of the landowners and by the land laws which had withdrawn land from the mainstream of commerce, ${ }^{333}$ argued that the latter merely reinforced the former, representing the ideas and meeting the desires of the landed classes. ${ }^{334}$

The weakenings of the rigid, historical limitations on property rules cannot be denied. Land no longer represents the most powerful or the sole form of wealth; nor does it now stand as a symbol of absolute political power or otherwise unattainable social privilege. The creation and redistribution of new and traditional forms of wealth have dramatically altered the assumptions upon which property rules were first developed to protect only a narrowly defined class of contract entitlements. The application of property rules to promissory entitlements is not a static construct but, like contract law itself, reflects and shapes social and cultural norms. Contract does not, whether or not we are comfortable with its dynamic nature, exhibit well-settled principles ${ }^{335}$ but rather involves an ongoing interaction with other social institutions, responding to change which may have been born outside the legal system but which, at the same time, has been sculpted by the law. ${ }^{336}$ The evolving economic, political, social, and cultural attributes of land and labour and the corresponding modifications of the rules protecting contractual entitlements are indeed reform movements.

The progression of society from status to contract reflects a restructuring of individual relationships away from immutable, hierarchical allocations of authority, grounded not only in family but more directly in the 'tenurial relation of man to man,' in 'estates and tenure of land.'337 Social relationships today are not static, involving as they do an ongoing struggle to achieve some semblance of balance between institutions, as well as individuals, insisting on respect for divergent or antipodal interests. To the extent that society allows the creation and definition of relationships through private expressions of free will either by individuals acting alone or by collective institutions of labour, capital, and consumer interests, contract cannot remain burdened under eighteenth-century ideals of status in land. Our conception of property over the centuries has exhibited only one constant, and that constant is that the meaning of property will always change. There is nothing either in history or in reason to support a thesis which would exempt property rights in contract from this evolutionary process, and it thus becomes imperative that the law, if it is founded in social consensus, must respond to the values and forces which have shaped contractual expectations and private obligations in our society. 
NOTES

1 Guttsman The British Political Elite (1963) 127

2 See Waddams The Law of Contract (1977) 421 ; Treitel The Law of Contract (5th ed 1976) 1. Anson's Law of Contract (24th ed 1975) 1; Atiyah An Introduction to the Law of Contract (2nd ed 1971) 1; Swan and Reiter Contracts Cases, Notes and Materials (1978) xxxi.

3 Libling, The concept of property: Property in intangibles (1978) 94 Law Q. Rev. 103, 104. Leff describes this interaction of supply and demand - the sale - as having been 'ostentatiously neglected by almost all scholars in almost all pertinent disciplines, thus denying all of us the aesthetic joy of what is really a very pretty story.' Leff Swindling and Selling (1976) 6. It is my hope to flesh out the picture which lawyers and legal scholars have traditionally drawn of the sale of land.

4 Ely in 2 Property and Contract (1919) 561 , who makes this point in arguing that contracts (defined as agreements enforceable by public authority) are property, fails to distinguish among the alternative modes of legal enforcement available in our society.

5 See Farnsworth, Legal remedies for breach of contract (1970) 7o Col. L.R. 1145, 1147 ; Simon and Novak, Limiting the buyer's market damages to lost profit: A challenge to the enforceability of market contracts (1979) 92 Harv. L.R. 1395, 1398-402. Holmes The Common Law (1881) 299-301.

6 See Atiyah, Contracts, promises and the law of obligations (1978) 94 Law Q. Rev. 193,

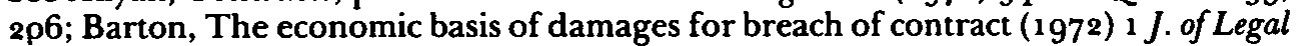
Studies 277.

7 This analysis begins with the obvious point that property is most often defined and assessed according to the degree of protection which society affords it, not merely against an individual (ie, one's promisor), but against the world at large. See Atiyah The Sale of Goods (5th ed 1975) 141; Scanlon, Liberty, contract and contribution, in Dworkin, Bermant, and Brown (eds) Markets and Morals (1977). Thus the bipolar paradigm used to describe contractual relationships, in so far as one is engaging in an examination of contract as property, is not entirely accurate. If one decides to protect contract entitlements by specific performance, one is obligated to decide a collateral matter, that is, how to allocate, adjust, and resolve conflicting claims to contractual performance between the original promisee and a second or even a third or fourth promisee who has contracted with the same party as did the first, either with knowledge or in ignorance of the prior agreement. Allocation of loss between two 'innocent' parties has long been characterized by irreconcilable and intractable normative difficulties. One response has been the promulgation of registration regimes, notoriously complex and expensive, designed to resolve, avoid, or at least ameliorate conflicting claims arising on the protection of contract entitlements by property rules. Another, it might be argued, has been the evolution of legal rules permitting compensation in the form of damages rather than specific performance - a demonstrably effective technique of avoiding third-party disputes.

For the most part, this essay will focus on bilateral entitlements - a choice between performatory and substitutionary obligations only in so far as the interests of the immediate contracting parties are at issue. The global notion of property can, it seems, be put at least temporarily to one side. It is open to enforce contract entitlements by property rules, but for other reasons - including reliance on ostensible ownership, possessory rights, or commercial efficacy - to allow others to interfere with the resulting bilateral property rights unless the possessor of those rights has done something more than merely contract in private. Thus, in the case of sales, the passing of 'property,' which historically has been tied to specific relief, has had only a minor role to play in determining property rights as against the world; 'if we look at the other effects of the transfer of property as between seller and buyer in the common law systems, we shall see that they are for the most part, if not entirely, illusory.' Lawson, The passing of property and risk in sale of goods - A comparative study (1949) $6_{5}$ Law Q. Rev. 352, 354. Callman, He who reaps where he has not sown: Unjust enrichment in the law of unfair competition (1942) 55 Harv. L.R. 595, 597. A nice example of this point is the recent case of Gyger v L'Arrivee (1977) 3 B.C.L.R. $3_{4}$. 
Specific performance is certainly of great import to members of the public who cannot but be concerned as to the identity of the person who has the legal right to transfer an interest in the property. An analysis of specific performance, however, may focus on mere relational property rights, leaving exclusive property rights arising out of performatory obligations, which cast a far broader shadow, to another time.

8 Traditional Anglo-Canadian judicial reasoning in cases in which promissory expectations have been raised to the status of property offer little insight as to the forces operating to justify a decision in favour of performatory obligations. For example, Martland $\mathrm{J}$ in Canadian Long Island Petroleum Ltd. et al. $\mathrm{v}$ Irving Industries (Irving Wire Products Division Ltd. et al. (1975) 5O D.L.R. (3d) 265, 277 , openly rationalized holding a contractual right of pre-emption as an interest in land (as a subspecies of option) on the 'underlying theory ... that the option to purchase land does create an equitable interest because it is specifically enforceable.' Ibid, at 277 . See also Frobisher Ltd. v Canadian Pipelines Ltd. et al. (1958) 21 D.L.R. (2d) 449 (s.c.c.). Morris and Leach The Rule Against Perpetuities (2nd ed 1962) 21 , 220 . Jackson Principles of Property Law (1967) 301, 302, 399. Precisely the opposite result obtains in Australia, where a right of pre-emption has been held to constitute a mere contractual interest. Mackay v Wilson (1947) 47 S.R. (N.s.w.) 315, 325. Harpum, Rights of pre-emption: Ugly ducklings into swans (1978) 37 Camb. L.J. 213 ; Scott, Options of purchase (1918) 38 Can. Law Times 242 . One discovers on reading the cases that the issue as to whether an option creates an interest in land is apt to be determined according to its consequences. If the outcome is the invalidation of the option-holder's rights (for example, under the rule against perpetuities), one is likely to find decisions describing the right as purely contractual - thus not constituting an interest in land. Where, however, an interest in land is a pre-requisite to certain rights (eg, where the land has been sold to a third party, and the validity of the holder's registration is challenged) a proprietary interest will miraculously appear. La Forest has made the point that protecting property rights effects fungibility, but concludes that the interest of the optionee, if recognized as a property interest, will bring the registration acts into play, leading to a clearer determination of priorities. He thus overlooks the point that priority conflicts might be avoided entirely simply by defining the optionee's interest as a claim in damages. La Forest, Real property - options rights of pre-emption - equitable interest in land - personal contractual obligation rule against perpetuities (1960) 38 Can. Bar Rev. 595. Similarly, in Warmington v Miller [1975] 2 W.L.R. 654, where the English Court of Appeal refused specific performance of an agreement for a sublease, Stamp iJ noted that the 'equitable interests which the intended lessee has under an agreement for a lease do not exist in vacuo, but arise because the intended lessee has an equitable right to specific performance.' Ibid, at 66. Megarry $\mathrm{J}$ has adopted the same restricted analysis, suggesting that 'the existence of an equitable interest in the purchaser as soon as the contract is signed depends upon the contract being specifically enforceable.' Megarry, Note (1960) 76 Law Q. Rev. 200, 202; Mapp, Torrens' elusive title (1978) 1 Alta. L.R. (Book Series) 162.

Yet others have argued precisely the converse - that specific performance is available because the claimant has acquired an equitable interest in the property. Heathcote $\mathrm{v}$ The North Staffordshire Railway Company (1850) 2 M. \& G. 110,112 . The courts consistently fail to explore beyond that point, justifying the creation of property rights in contract on the availability of specific performance, and the availability of specific performance on the existence of property rights, leaving the law no wiser than it was before. Brandeis $\mathrm{J}$, in International News Services v Associated Press (1918) 248 U.s. 215 , admitted the obvious in recognizing the shallowness of the traditional view for what it is. If we are to understand why property rules are only sometimes applied to protect contractual entitlements, we must, at the outset, jettison the tautological reliance on the right to specific performance as the prerequisite to the creation of property rights and the existence of property rights as a pre-condition to an order of performance of a promissory obligation: 'The doctrines relating to specific performance do not, I think, afford a test or measure of the rights created. There are cases where the rights of the parties may be worked out by specific performance though no specific lien is created. 
More frequently, a specific lien is created though no case of specific performance is contemplated.' Tailby v Official Receiver (1888) 13 App.Cas. 523, 548.

9 The classic argument put forward for limiting curial jurisdiction to order specific performance is 'respect for individual freedom,' the right to freedom of contract reflected in the concomitant freedom to breach. Keeton and Sheridan, Equity (and ed 1976) 36o. O'Neill, Specific performance of a contract for purchase and sale of land (1973) 21 Chitty's L.J. 109. The view that specific performance constitutes a direct infringement of personal liberty is reflected in decisions establishing the power to order performance of contractual obligations in the judiciary rather than in administrative agencies in some circumstances. See Reference re Constitutional Questions Act (Alberta) (1978) 7 R.P.R. 104.

The time-honoured phrase 'The law of England will not permit any man to enslave himself by contract' (Somersett's case, 20 St. Tr. 1; Stocker v Brocklebank (1851) 42 E.R. 257) and the historical and somewhat archaic doctrine forbidding the ordering of performance of contracts of personal service need no elaboration here. See Marsh, Specific performance of contracts for continuous personal relations (1894) 14 Can. Law Times 1; Emerald Resources Ltd. v Sterling Oil Properties Management Ltd. (1969) 3 D.L.R. (3d) 63o, 647, affirmed 15 D.L.R. (3d) $256 \mathrm{n}$; Garnett v Armstrong (1978) 83 D.L.R. (3d) 717 (N.B.S.C.A.D.); Rushton v McPherson [1939] 4 D.L.R. 781 n, 14 M.P.R. 235; McWhirter v Governors of the University of Alberta (1978) 80 D.L.R. (3d) 609 .

There can be little doubt that the protection of a contractual obligation by a property rule impacts more intrusively on the liberty of one who interferes with it than does protection by a liability rule. Where the value of the promised performance is, to the plaintiff, identical to the value of the damage award, the only consequence of an order for specific performance will be to deprive the defendant of a choice between alternative courses of behaviour. If ordered to perform, he can comply, ignore the judicial direction and thus risk incarceration, or bargain with the claimant under the handicap of a judicial order in the other's favour. Where a contract entitlement is protected only be a liability rule, the defendant can choose to perform, either by locating a new contractor or by performing himself; he may renegotiate the contract, or, as is more common, he can compensate the plaintiff through a transfer of money raised in a manner which generates the least cost to him. Simpson $A$ History of the Common Law of Contract (1975) 597. In Bromage v Genning (1616) i Rolle 368 an action had been commenced to compel the defendant to execute a lease. A prohibition against the action was sought, and Lord Coke said that 'this would subvert the intention of the covenantor when he intends it to be at his election either to lose the damages or to make the lease, and they wish to compel him to make the lease against his will; and so it is if a man binds himself in an obligation to enfeoff another, he cannot be compelled to make the feoffment.'

10 An order for performance of even a simple contract of sale may catalyse substantial, time-consuming, and intractable disputes involving the manner and time of delivery, the quality of the property transferred, claims of third parties, misunderstandings as to allocation of responsibility for obligations which continue after delivery, and the like. In the regular course of events, these expected nonconformities with contractually assumed obligations are often resolved informally through private negotiation - by promises to cure, modification and renegotiation of future sale contracts, or price adjustments. An order for performance, unlike a damage award, which in terms is as simple an obligation as one might conceive, obliges the court to take upon itself the myriad risks attendant upon contract. If the plaintiff is, or ought to be, indifferent as to a compensatory or performatory award, the choice is obvious.

Difficulties of supervision with respect to the exactitude of the ordered performance, administrative costs imposed by a judicial supervisory role, and the lack of expertise in the judiciary have been proffered, over time, as explanations for refusals to order performance. See generally Dominion Coal Co. Ltd. v Dominion Iron E Steel Co. Ltd. [1 gog] A.C. 893; Powell Duffryn Steam Coal Co. v Taff Vale Railway (1894) LR 9 Ch. App. 331; Ryan v Mutual Tontine Ltd. [1909] A.C. 293; Powell Duffryn Steam Coal Co. v Westminster 
Chambers Association [1893] \& Ch. 116 (C.A.) (promise to provide a porter held not specifically enforceable). A common example of the attitude of the courts towards specific performance is presented by the case of construction contracts - which are not generally specifically enforced on the ground that the judicial branch of government has neither the resources nor the expertise to engage in extended and exacting supervision of private obligations. Yet again the rule is not absolute. Tanenbaum $\mathrm{v} W . J$. Bell Paper Co. [1956] O.R. 278; Gross v Wright [1923] S.C.R. 214, 219. Williston suggests that traditional judicial conservatism is due to the difficulty of enforcing a decree without an expenditure of effort disproportionate to the value of the result.' 5 Williston on Contracts (1937) 3976-7.

It is clear that the mere presence of uncertainty or ambiguity in the order or the requirement of judicial supervision will not be dispositive. Thus a vendor has been ordered to make an application to a land planning authority for a subdivision approval in Dynamic Transport Ltd. v O.K. Detailing Ltd. (1978) 85 D.L.R. (3d) 19; Hogg v Wilken et al. (1974) 51 D.L.R. (3d) 511 ; Steiner et al. v E.H.D. Investments Ltd. (1977) 78 D.L.R. (3d) 499 leave to appeal to the Supreme Court of Canada refused 14 December 1977). A contrary view was expressed in E.J.H. Holdings Ltd. v Bougie et ux. (1977) 3 Alta. L.R. 244. Similarly a company has been ordered to apply for permission to deal on the London Stock Exchange. Northern Counties Securities Ltd. v Jackson \& Steeple Ltd. [1974] 2 All R.R. 625.

11 It is easy enough to see that the social obligation arising on contract has been defined in a manner which limits the intrusive nature of the judicial role. While we might have chosen to establish a legal obligation to perform a specific task, we have created a more generalized obligation to transfer wealth in the form of money, allowing each individual to retain the freedom to act as he wants, subject only to this economic restraint. The similarity between this perception of individual contract obligation fulfilled through a transfer of money and a more generalized social obligation again met through a transfer of money rather than services or performance is remarkable: 'One reason why taxation seems generally thought to be a more acceptable form of required contribution than, say, a system of required tasks or a requirement of payments in kind is that it leaves citizens with greater latitude in deciding how to arrange their lives while still meeting their social obligations.' Scanlon, Liberty, contract and contribution, supra note 7 . Nozick, however, has denied the distinction: 'Taxation of earnings from labor is on par with forced labor.' Nozick Anarchy, State and Utopia (1974) 169 . See generally Cooley $A$ Treatise on the Law of Taxation (2nd ed 1886) 13-15. McCulloch describes 'labour taxes, or contributions of personal services for the execution of public works,' as 'among the very worst species of taxes.' McCulloch $A$ Treatise on the Principles and Practical Influence of Taxation and the Funding System (3rd ed 1863) 44-50 in Scottish Economics Classics Ed (O'Brien, ed, 1975).

12 Some writers who have thought about why we enforce some promises through specific performance and leave others to damage awards have analysed decisions as to the grant or denial of specific enforcement in terms of the dangers inherent in assessing value in the absence of objective, accessible market price information. Kronman, Specific performance $\left(1^{878)} 45\right.$ U. Chi. L.R. 351, 352, 353. Trietal, Specific performance in the sale of goods,' [1966] J. of Bus. Law $211,216$.

Property rules have been chosen as the preferred mode of protecting certain classes of contractual entitlements, not on the basis of any intrinsic quality or value of the performance, but on the notorious risks of over-compensation or under-compensation attendant upon subjective assessment of value. As long ago as 1824 specific performance of a contract for the sale of a debt upon which dividends were to be paid was ordered on the ground that damages could not 'accurately represent the value of the future dividends; and to compel this purchaser to take such damages would be to compel him to sell those dividends at a conjectural price.' Adderley v Dixon (1824) i Sim \& St. 607, 612; 57 E.R. 239. In essence, we recognize that to limit the protection of a promissory entitlement to liability rules is to force its 'sale' at an objectively and collectively determined price. If the price to be charged cannot be determined with any 
degree of precision or without a substantial expenditure of judicial resources, we are apt to protect the entitlement by a property rule. For example, in Tanenbaum $\mathrm{v} W$.J. Bell Paper Co. Ltd., supra note 10 , at 309,310 , the assessment of the present value of the cost of road-repair over ten years was said to be 'quite impossible to do with any degree of accuracy' in the light of the uncertainty as to the frequency and kind of use and the cost of money in the future. Accordingly, the contract for the construction of the road was ordered performed.

Similar difficulties of assessment have generated corresponding judicial responses in a range of substantive areas of law. The well-known practice of enjoining an infringement of trade mark rights has been defended on the ground that 'the common law remedy in such situations, involving guesses as to loss of profits, is hopelessly inadequate.' Robinette, Protection of property interests in equity (1932) 10 Can. Bar Rev. 172, 177 .

Stoljar has argued, on the same lines, that the right of a purchaser who is offered a late delivery to reject the goods for breach of condition in the absence of proof of loss is a response to uncertainties in damage assessment. Delay, of itself, may not result in a directly calculable economic loss, and, even where it does, its assessment raises intractable problems. The response - allowing the buyer to repudiate even in the absence of demonstrable loss - is simply a means of allocating the risk of uncertainty in damage assessment to the party in breach. See Thomas Borthwick (Glasgow), Ltd. v Bunge E Co., Ltd. [1969] Ll. R. 17, 28; Bowes v Shand (1877), 2 App. Cas. 455; Atiyah The Sale of Goods (4th ed 1974) 6o; Avon छ Co. v Comptoir Wegimont [1921] 3 K.B. 435. Stoljar, Untimely performance in the law of contract (1955) 71 Law Q. Rev. 527, 528. The result is to place the entire risk of market fluctuation on the seller if he breaches his delivery obligation by even a day. Bowes $v$ Shand, ibid, per Mellish LJ at 116 ; Reuter v Sala (1879) 4 C.B.D. $239,257$.

The same complexities inherent in demonstrating value in the absence of market price information and the dangers of over-compensation or under-compensation often underlie the recognition of liquidated damages clauses in building and construction contracts. Such provisions are especially important in the case of unprovable anticipated losses, where the adoption of stipulated compensation allows the parties to 'insure' their losses by agreeing on a set price for the entitlement, and to reduce the process costs incurred in determining the value of the expected performance. Stoljar, ibid, at 528; Goetz and Scott, Liquidated damages, penalties and the just compensation principle: Some notes on an enforcement model and a theory of efficient breach (1977) $77 \mathrm{Col}$. L.R. 554. Section 2-718(1) of the Uniform Commercial Code acknowledges that the reasonableness of a liquidated damages clause stands to be determined, in part, on the 'difficulties of proof of loss.'

The archtypical case of non-market valuation is presented by land, which, because each parcel of realty is 'unique,' cannot, in theory, have a true market value. It may, of course, be virtually indistinguishable from neighbouring lands, and the sale of similar, albeit non-identical, lands may provide information as to the value of the promised performance; but again the costs and uncertainty of assessment are notorious. Hogg v Wilkin (1975) 51 D.L.R. (3d) 411 (noting speculative nature of damage award and risks of over-compensation or under-compensation in cases of contracts for the sale of land). A typical case is Harris et al.v Dartington Properties Ltd. (1978) 6 B.C.L.R. 88, where evidence led by the plaintiff established the value of the land at $\$ 51,450$, expert evidence led by the defendant established the value at $\$ 80,000$, and the defendant himself testified that the land was worth $\$ 61,500$. The decision - placing a value of $\$ 6_{5}, 000$ on the land was an uneasy compromise.

In Hechter and Reycraft $\mathrm{v}$ Thurston [1978] 1 w.w.R. 695 Nitikman J considered the evidence of a qualified appraiser as to the value of real property, the absence of sales of comparable property, deficiencies in accessability, and the irrelevance of sales of property of different areas and characteristics and admitted that the evidence of value in assessing damages for breach of contract was 'not very dependable.' See also E.J.H. Holdings Ltd. v Bougie et al. (1977) 3 Alta. L.R. (2d) 244. 
The absence of a market in land is arguably of far less significance today than in the eighteenth century, when the rules protecting promissory entitlements were developed. See Reiter and Sharpe, Wroth v Tyler: Must equity remedy contract damages? (1979) 3 Can. Bus. L.J. 146, 151. As one text puts it, 'How much sense the "uniqueness of Blackacre" idea ever made is questionable. It makes no sense at all when translated into the brave, new world of Levittown in which land seems to have become fungible as wheat or corn or oil.' Kessler and Gilmore Contracts, Cases and Materials.(2nd ed 1974) 994 .

13 Several writers have suggested that specific performance ought to be the preferred remedy in contract law - or at the very least should be granted more readily than it is today. They argue, quite persuasively, that the judicial order (or, more precisely, the perceived likelihood of the order) creates an environment in which the party who chooses to break his contractual obligation must transfer some, not all, of the wealth generated by the breach to his contracting partner. He will not transfer all of his new-found wealth, since he would be left in no better a position than he would have been in had he not decided to breach. Rather, he will transfer some of this benefit to the plaintiff, thus leaving himself better off than if he had fulfilled his contract, and leaving the innocent plaintiff with a portion of the wealth as well. One difficulty with this thesis is the probability of negotiation taking place. While the perceived likelihood of an order for performance will provide the potential defendant with an incentive to negotiate which would not exist if damages were to be awarded on breach, there is no obvious corresponding incentive to negotiate from the point of view of the innocent party. He will, if he so desires, enjoy the entire benefit of the original contract, and may enjoy the increased wealth now enjoyed by the contract breaker, without having to transfer any portion of the latter wealth.

It is true, nonetheless, that the non-breaching party may be willing to negotiate an exchange of his property (ie, his potential right of specific performance) in return for money, thus establishing in monetary terms the subjective value of the contract to him. The negotiation may come about in view of the ever-present uncertainty flowing from evidentiary requirements, potential appeals, the exercise of judicial discretion, and the risk of intervening legislation or administrative regulation affecting the transaction. Moreover, the delay inherent in a judicially ordered transfer of property may provide a powerful incentive to negotiate an exchange of the right to specific performance in return for an immediate transfer of wealth. This is not, of course, to ignore the non-compensable legal litigation costs and the similarly non-compensable personal litigation costs including stress, foregone opportunities, fear of retribution, and the like, which may also lead to negotiation.

The distributive consequences of property rules have been the subject of judicial comment which emphasizes the process of contractual renegotiation between two parties where one, but not the other, is subject to a judicial order to perform the contract - a law, so to speak, 'passed' with only the defendant in mind. Advocates of specific performance have denied the coerciveness of this enforcement mechanism, arguing that it simply obliges the parties to negotiate a price for the right to breach $-\mathrm{a}$ thesis which may or may not be supported by the common experience that the issuance of an injunction or an order of specific performance typically settles the issues in dispute. Lord Denning has suggested that settlement is reached in 99 cases out of 100 where preliminary injunctions are issued. Fellowes v Fisher [1975] 2 All E. R. 829, 836. See Prescott, Note (1975) 91 Law Q. Rev. 168. The opportunity to renegotiate assumes, however, that a fair bargaining process will exist, and as long ago as ${ }^{186}{ }_{3}$ in Isenberg $v$ East India House Estate Co. (1863) 3 De G.J. \& S. 263 Lord Westbury pointed out the dangers inherent in an order for specific performance, fearing that the defendants would 'be made subject to any extortionate demand' (ibid) which the plaintiff might impose. More recently, Graham J insisted that if an injunction were to be employed in order to compel a market exchange, the claimants 'must not be treated as if they were in the extremely powerful bargaining position which an interlocutory injunction would have given them.' Bracewell v Appleby [1975] i Ch. 408, 419. The individual nature of 
the mandatory judicial order may have a compelling psychological impact which is absent in the vague, generalized notion of legal duty which most often reinforces contractual performance. As Chayes notes, an injunction may constitute a far more severe restraint on behaviour than the risk of future liability in money damages. Chayes, The role of the judge in public law litigation (1976) 89 Harv. L.R. 1281 . One purpose of liability rules, and the consequent objective assessment of damages, may be to ensure that the price paid by the defendant is not distorted by the shadow of a judicially imposed duty to perform on pain of imprisonment for contempt.

On balance, while it may be valid to argue for a distributive element in an order for specific performance, experience suggests that performatory obligations 'may prevent a negotiated solution rather than bringing it about.' Pearce The Valuation of Social Cost (1978) 13; Posner Economic Analysis of Law (2nd ed 1977) 97.

14 Calabresi and Melamed, Property rules, liability rules and inalienability: One view of the cathedral (1972) 85 Harv. L.R. 1089 . See also Hale, Coercion and distribution in a supposedly non-coercive state (1923) 38 Pol.Sc. Q. 470.

15 Calabresi and Melamed, supra note 14, at 1106,1107

16 Kronman, supra note 12

17 Bentham Theory of Legislation, Principles of the Civil Code 137 (Hildreth, ed, 1840) 137

18 Philbrick, Changing conceptions of property in law (1938) 86 U. Pa. L.R. 691, 694

19 Kronman, supra note 12 , at 353

20 Horwitz has described the antiquated and generally disparaged theory that contracts were, in essence, transfers of title. Horwitz, The historical foundations of modern contract law (1974) 87 Haro. L.R. 917, 920-3.

21 Maitland insists that '[o]n the whole ... specific performance applies to agreements for the sale or the lease of lands as a matter of course.' Maitland Equity (1910) 240. In Kloepfer Wholesale Hardware and Automotive Company Ltd. v Roy [1952] 2 S.C.R. 465, $47^{2}$ the Supreme Court of Canada said that 'generally speaking, specific performance applies to agreements for the sale of land as a matter of course.' In recent years we have witnessed a departure from the strictness of the rule, especially where the motives for the purchase of land are speculative. Chalk v Fairview Construction Ltd.(1978) 33 A.P.R. 13; [1977] 3 R.P.R. 117 . One commentator over a half-century ago proposed that sales of land not be specifically enforced when the contract is of a speculative nature. Heap, A draft of a proposed code on the subject of the sale of lands (1922) 42 Can. Law Times 257. In Prittie v Laughton (1902) 1 O.W.R 185 specific performance of a land contract was refused on the grounds of the purchaser's speculative intentions. American courts have for a number of years been willing to assess the motives of the purchaser in determining whether specific performance of a contract to sell land should be enforced. Where the motives are speculative, damages will be the likely remedy. See Bird and Fanning, Specific performance of contracts to convey real estate (1935) 23 Ky. L.J. 380 . See Watkins v Paul 95 Idaho 499, 511 P. 2d 781 (1973); Suchan v Rutherford 9o Idaho 288, 295, 296; 410 P. 2d 434, 443 (1966); Paddock v Davenport 108 N.C. 71 o; 12 S.E. 464 (189o). Recent decisions in Canada contain references to a similar philosophy. See 306793 Ontario Ltd. in Trust v Rimes (1979) 25 O.R. (2d) 79 per MacKinnon A.C.J.O. at 81; Heron Bay Investments Ltd. v Peel Elder Developments Ltd. (1976) 2 C.P.c. 338, 339. See generally Brenner, Specific performance of contracts for the sale of land purchased for resale or investment (1978) 24 McGill L.J. $5^{13}$.

22 The first suspicion that the development of property rules to protect promissory entitlements does not rest entirely on the intricacies and risks inherent in assessing damages is the well-established, indeed ancient, practice of awarding 'compensation' when specific performance is ordered, and where the transferor cannot convey all that he promised. See Wood v Griffith (1818) i Swan. 43; 36 E.R. 291 (purchaser successful in compelling vendor to convey limited interest, with compensation adjusted in accordance with the diminution in the value of the interest transferred); Mortlock $\mathrm{v}$ Buller (1804) 10 Ves. 292; 32 E.R. 857 (purchaser granted specific performance with abatement of purchase price); Bowes v Vaux (1918), 43 O.L.R. 521 (area of land smaller than that contracted for, specific performance with compensation ordered); Mason $\mathrm{v}$ 
Freeman [1958] s.C.R. $4^{83}$ (refusal to bar dower by vendor's wife, specific performance with compensation respecting the diminished value of the land ordered). See Harpum, Specific performance with compensation as a purchaser's remedy - A study in contract and equity [1981] Camb. L.J. 47 .

The risks of error resulting in over-compensation or under-compensation, and the intricacies of assessment in cases of partial contractual performance are as prevalent as in the case of valuing the entire property, but this, as Fry notes, has not interfered with the development of liability rules to augment property rules; the law did not hesitate to value land where performance was demanded: 'Where the difference in value of the interest contracted for and the interest that can actually be conveyed is incapable of computation, the Court will not enforce specific performance. But having regard to some of the decided cases already referred to, it is conceived that the Court will seldom now consider a difficulty of this kind insuperable ... The objection that the compensation is unascertainable is, as has been already in substance observed, one which the Court is unwilling to entertain' (emphasis added). Fry Specific Performance (2nd ed 1881) 539, 540.

Although one might concede that the complexities and likelihood of error in ascertaining the value of land in the seventeenth and eighteenth centuries (when no market existed in which the prices of land bought and sold might have served as an accurate proxy for value) may have provided a powerful incentive for a remedial tool which would avoid the costs generated by non-market valuation, it would seem that other forces were at play in shaping and colouring the evolution of the law. As Maitland put it, 'even if land can be said to have a market value, still a man may well have consented to pay more ... to him the land may have a fancy value.' Maitland Equity (2nd ed 1936) 238. This attitude was typical of judicial discourse of the eighteenth and nineteenth centuries. In Adderley v Dixon (1824) 1 Sim. \& St. 607, Sir John Leach vc commented that 'damages at law ... may not be a complete remedy to the purchaser, to whom the land may have a peculiar and special value' (ibid, at 610); and in 1746 Lord Chancellor Hardwicke observed that specific performance of land contracts would be decreed as a matter of course, a purchaser agreeing to buy 'on a particular liking to the land.' Buxton v Lister and Cooper (1 746), 3 Atk. 383,384 . Even earlier, in 1719 , land was pictured as a 'matter of moment and use,' Cud v Rutter (1719) P. Wms. 570; 24 E.R. 521. Remarks by councel at 571 ; being 'more commodious, pleasant or convenient than another parcel of land' (ibid). Fry, while admitting the difficulties inherent in assessing value in the absence of market information, argued that 'one landed estate, though of precisely the same market value as another, may be vastly different in every circumstance that makes it an object of desire.' Fry Specific Performance (2nd ed 1881) para 43.

23 The centrality of land contracts to English law and legal institutions is most evident in the direct disobedience of the Court of Equity in enforcing parol contracts in the face of legislation enacted in 1677 imposing formalities on the legal recognition (in any form) of promissory entitlements in respect of land. The Statute of Frauds (1677) 29 Car. 2, s. 4 required that every 'Contract or Sale of Land, Tenements or Hereditaments, or any Interest in or concerning them' must be evidenced in writing. Holdsworth has exhaustively detailed the history of the statute. Holdsworth, 6 History of English Law (1924) 379-97. The courts devised means to avoid the statute within seven years of its enactment. Butcher v Stapeley (1685) i Vern. 363. See Law Reform Commission of British Columbia Report on the Statute of Frauds (L.R.C. 33, 1977); Spry Equitable Remedies (1971) 233; Pollock, Principles of Contracts 521 (13th ed., 1950).

24 Judicial attitudes in the case of credit transactions in which the debtor's land was pledged as collateral stood in stark contrast to the rigour of enforcement, at common law, of more common contractual obligations. The intrusion of equitable doctrines to allow the landowner further time to meet his debt obligation so as not to forfeit his land has been justified by one judge in almost religious terms - a product of 'the piety or love of fees of those who administer equity.' Salt v Marquess of Northampton [1892] A.C. 1, 19. Although security agreements in which personal property was impressed with debt obligations have, in some cases, been assimilated to the position of mortgages of realty, 
Maitland could still say, as recently as 1910 , that 'mortgages of such things ... have nothing to do with the doctrines of equity,' Maitland, supra note 22, at 193, 194 . Ashburner makes the same point. Ashburner Principles of Equity (1902) 257, 261. Rules protecting entitlements in the case of mortgages have little in common with the property rules applied to protect promissory entitlements in the case of purchases. In contracts of purchase, the law specifically compels a transfer of land, protecting the purchaser's entitlement through the invocation of a property rule. In the case of a contract to transfer land on default of a debt obligation, however, the entitlement of the 'purchaser' (ie, the prospective transferee-mortgagee) is protected merely by a liability rule. In most cases, the law modifies his consensual rights, giving the debtor further time to pay. At best, he receives only his damages - the law insisting that the land be sold, with the surplus generated by the sale to be returned to the owner. Thus the contractual entitlement of the mortgagee can be destroyed by the mortgagor on payment of compensation for the mortgagee's losses.

25 Infra, at notes 300-11

26 Maitland Constitutional History (1908) 538 . Watkins writes that 'from [the feudal] system are derived our laws relative to property.' Watkins The Law of Tenures (1824) xxv, xxvi. Mcllwain, in The Growth of Political Thought in the West (1932) 177, 182, 355, details a similar confusion of public and private authority.

27 What I mean by 'economic foundation' is simply that the individuals who are involved in the exchange process must perceive, or be prepared to perceive, the commodities that are being traded as being reducible to monetary equivalents. The wheat, or machinery, or shares represent a certain sum of money which has only temporarily assumed the guise of a tangible object. The 'economic foundation' of the contract reflects the financial motivations and expectations of the parties engaged in the trade.

28 'Social needs are the essential life that give vitality to all legal institutes.' Philbrick, supra note 18 , at 694 . See also Reich, The new property (1964) 73 Yale L.J. 733. Watkins, writing of the feudal system observed that 'to it must we have recourse, in order to account for the origin and utility of many [laws] which might otherwise appear useless or unjust; and to it must we continually recur, to explain and illustrate what might otherwise seem dictated only by caprice.' Watkins, supra note 26 , at xxvi.

29 Adams Garrow's Law of Real Property (5th ed 1961) 2. Cheshire writes that 'land constituted the sole form of wealth.' Cheshire on Modern Real Property (1925) 4. Topham comments that 'land was by far the most important form of wealth.' Topham's Real Property (5th ed 1961) 2.

30 Williams The Law of Real Property (1845) 1,5 (emphasis added). See also, Pollock The Land Laws (1883) 53. In 1836 the value of fixed property in England was calculated to be $£_{3,327}$ million, out of an aggregate national capital of $£_{4,305.5}$ million. Manufacturing and commercial capital, exclusive of ships, was said to represent only 5 per cent of the English national wealth. List The National System of Political Economy (1909) 192, 193. Brodrick has described the appreciation in land values during the nineteenth century. Brodrick English Land and English Landlords (1881) 84-8.

31 Cheshire, supra note 29, at 6

32 Stamp The Land of Britain (1946) 241

33 Dicey, The paradox of the land law (1905) Law Q. Rev. 221,226

34 (1874) L.R. 7 H.L. $15^{8}$

355 Corbin on Contracts (1964) 531

36 Mayne Treatise on Damages (5th ed 1894) 212-14

37 Honsford v Waight 1 Kirby 3 (Conn. 1786)

$3^{8}$ See Stone The Causes of the English Revolution 1529-1642 (1972) 73, 77

39 Haskins, Extending the grasp of the dead hand: Reflections on the origin of the rule against perpetuities $(1978) 126 U . P a . L . R .19,24$. Of course land did have value as a source of economic wealth through agriculture, urbanization, and pressures of population, and many have detailed the increased profitableness and resulting demand for land in the late sixteenth and early seventeenth centuries. As Tawney wrote: 'During the decade between $154^{\circ}$ and $155^{\circ}$ there was a furor of land 
speculation. To the Abbey lands, which came into the market after 1536 , were added those of the guilds and chantries in 1547. It is quite clear that some of the grantees of estates did not acquire them with the intention of retaining them, but simply "bought for the rise." Tawney The Agrarian Problem in the Sixteenth Century (1912) 35, 381. 2 Cunningham The Growth of English Industry and Commerce (6th ed 1925) 105.

40 Dickinson Liberty and Property. Political Ideology in Eighteenth Century Britain (1977) 51

41 I Mill Principles of Political Economy (5th London ed 1893) 294. Guttsman concludes that the landed estate considered as a financial investment was, even through the nineteenth century, inferior to industrial or commercial property. Guttsman, supra note 1 , at 127 .

42 The Australian experience was similar - land quickly became a marketable commodity, and land ownership was far more diverse than in England. Whalen, Immediate success of registration of title to land in Australia and early failures in England (1967) 2 N.z.U.L.R. 416, 423-24. Morden reveals a decidedly realistic attitude to the dramatic differences between England in the eighteenth century and Canada at the turn of the twentieth, suggesting that 'the obvious fact that land was plentiful' in Canada explains the departure in philosophy of Canadian expropriation legislation from its English predecessors. Morden, The new expropriation legislation: Powers and procedures in The Law Society of Upper Canada, Special Lectures, Recent Developments in Real Estate Law (1975) 225, 238-41. Land in England no longer exhibits the price stability it once did. Drewett, Land values and the suburban land market in 2 Hall (ed) The Containment of Urban Land (1973) 220-2. The Law Commission in England reacted to rapid increases in land values by proposing substantive reforms in the law of contract to protect the interests of prospective purchasers of land. See Law Commission Transfer of Land 'Subject to Contract' Agreements 1-3 (Working Paper No. 51, 1973). The commission retreated from its proposals in its report on the same topic. Law Commission Transfer of Land. Report on 'Subject to Contract' Agreements (Law Comm. No. 65, 1975). See generally Hall (ed) Land Values (1965).

43 Seymourv Delancy (1824) 3 Conv. 445, reversing (1822) 6 Johns Ch. 222 . See also Gates, The homestead law in an incongruous land system (1936) 41 Am. Hist. Rev. 655. Hibbard has described rampant land speculation in America as characteristic of the colonial and confederation periods. Hibbard A History of the Public Land Policies (1924) ch 12.

44 Pitcher v Livingston 4 Johnson's Rep. 1

45 McKinnon y Burrows (1834) 3 Q.B. (o.s.) 590; Kilborn v Workman (1862) 9 Ch 255. See Risk, The last golden age: Property and the allocation of losses in Ontario in the nineteenth century (1977) 27 U.T.L.J. 199, 210.

46 Moore Social Origins of Dictatorship and Democracy (1966) 8-13, 25-9; Gash Politics in the Age of Peel (1953) 177-181; Hobsbaum Industry and Empire 97 (1968).

47 See McCloskey, The enclosure of open fields: Preface to a study of its impact on the efficiency of English agriculture in the eighteenth century (1972), $32 \mathrm{~J}$. of Econ. Hist. 15.

$48 \mathrm{Ibid}$, at 23. See also Davies, The small landowner $1780-1832$, in the light of the land tax assessments (1927-8) I Econ. Hist. Rev. 87; Habakkuk, English land ownership, 1680-1 740 (1939-40) 10 Econ. Hist. Rev. 1; Beckett, English land ownership in the later seventeenth and eighteenth centuries: The debate and the problems (1977) 30 Econ. Hist. Rev. (2d series) $567,570$.

49 Cockburn Life of Lord Jeffrey $(1857) 18_{5}$

5o See Hanbury Essays in Equity (1933) 39

51 Burgess $v$ Wheate $(1759)$ i Eden. 177,$225 ; 28$ E.R. 652. The connection of land ownership and the right to vote is not, of course, the entire answer. For example it may not explain awards of specific performance (or rather the legal ancestors of specific performance) prior to 1430 . See Fry, supra note 22, at para 19; 1 Spence Equitable Jurisprudence $(1846) 644,645$; Newland $A$ treatise on Contracts $(1808) 88,89$. Simpson has collected a number of cases of specific performance of contracts to convey land in the mid-fifteenth century. Simpson, supra note 9 , at 595 .

Nor can the vote explain the specific enforcement of contracts for the sale of personal 
property or of land situated outside of England. See Fry, supra note 22, at paras 14, 23; Davis v Park (1860) L.R. 8 Ch 862; Toller v Carteret (1705) 2 Vern. 494; Penn v Lord Baltimore (1750) 1 Ves. Sen. 444. In addition, contracts relating to interests in land which did not carry the vote were specifically enforced. Hinton $v$ Hinton $(1855) 2$ Ves. Sen. 631,638 (contract to convey copyhold enforced).

A partial explanation for the discontinuity between the class of contracts for which specific performance would lie and the narrower class which would involve a transfer of the franchise may be found in the judicial response to the Statute of Frauds (29 Car. II, c. 3) in 1677 which proscribed the enforcement of parol contracts for the sale of land, including in the definition of land much more than freehold. Scriven Copyhold (and ed 1823) 262. The doctrine of part performance quickly arose as an equitable device which enabled Chancery to order the specific enforcement of parol contracts notwithstanding their unenforceability of law. The doctrine was applied, however, only to those contracts for which a Court of Equity would entertain or, in the view of some, grant a suit for specific performance. McManus v Cooke (1887) 35 Ch. D. 681,697 (doctrine of part performance applies to contracts in respect of which a court would entertain a suit for specific performance) Rink v March [1921] 1 w.w.R. 919 (part performance applies to contracts of which specific performance would be ordered ). See also Sarbit v Hanson and Booth Fisheries Can. Co. [1950] 4 D.L.R. 34, reversed on other grounds, [1952] 2 D.L.R. 108; Lavery v Pursell (1888) 39 Ch. D. 508, 518.

This doctrine created a powerful incentive to expand the equitable jurisdiction to award specific performance of a broad range of contracts notwithstanding that political rights were not necessarily at issue. Some authorities take a narrower position - that the doctrine of part performance applies only to contracts 'concerning land' or 'relating to land,' but this view has been widely criticized. Britain v Rossiter (1879) \& 1 Q.B.C. 123,129 , 131, criticized in Williams The Statute of Frauds (1932) 239; Maddison v Alderson (1887) 1 Mac. \& G. 572; 41 E.R. 1387 ; Fry states that the doctrine applies to 'all cases in which a Court of Equity would entertain a suit if the alleged contract had been in writing.' Fry Specific Performance (6th ed 1921) 283. Spry concurs in this opinion, citing numerous Australian authorities to that effect. Spry, supra note 23, at 237, 238.

52 Defoe The Original Power of the Collective Body of the People of England, Examined and Asserted (1702) 18

53 There is some debate as to whether the pre-1430 franchise extended to freemen or to freeholders. See Hodgins The Canada Franchise Act (1886) 14. Chalmers and Asquith, as well as Medley, argue that only freeholders elected members of Parliament prior to 1430. Chalmers and Asquith Outlines of Constitutional Law (3rd ed 1925) 334. Medley English Constitutional History (4th ed 1907) 195, 196. Professor Hearn discusses the possibility that only tenants in chief of the Crown voted prior to 1430 . Hearn The Government of England (1886) 534-7. In 1405 by 7 Henry IV, $c 15$ the franchise was expressly vested in all freeholders.

548 Henry vi, c 7 . The residency qualification was made explicit in 1432 by 10 Henry vi, c 7. Little attention was paid to the latter statute, and it was formally repealed by $14 \mathrm{Geo}$. III, c 68.

55 Prior to 1430 , parliamentary elections had been subject to serious disruption by the local populace. Lovell English Constitutional and Legal History (1962) 199, 200. Reiss The History of the English Electoral Law in the Middle Ages transl K.L. Wood-Legh (1973) 57-9

568 Henry vi, $c 7$

57 Plucknett Taswell-Langmead's Constitutional History (1oth ed 1946) 225; Wilkinson Constitutional History of England in the Fifteenth Century (1963) 289

58 i Blackstone Commentaries on the Laws of England (18th ed 1829) 173. Bishop Fleetwood in 'Chronicon Pretiosum' argued that the franchise requirement was equivalent to twelve pounds in the reign of Queen Anne. Cited in Leader The Franchise, A Manual of Registration and Election Law and Practice (1879) 54, and in Blackstone, ibid, at 173.

59 Medley, supra note 53 , at 196

60 In 1886 Hearn estimated the qualification as an eighteen-pound freehold. Hearn, supra note 53 , at 538,539 . 'The qualification thus prescribed was at the time (1430) a 
high limit.' Courtney The Working Constitution of the United Kingdom (1901) 59. Bailey estimates that a 40 -shilling freehold would be worth several hundred dollars in the middle of the twentieth century. Bailey British Parliamentary Democracy (1958) 61 at note 4. Gneist in 1889 suggested that the qualification would have to be raised to 100 to 800 shillings to take account of the change in the value of money. Gneist $A$ History of the English Parliament (3rd ed 1889) 391 .

61 See Bishop Fleetwood Chronicon Pretiosum 174 , cited in Blackstone, supra note 58 , at 173. Wilkinson estimated that the electorate represented in the Commons numbered some 10,000 . Wilkinson, supra note 57 , at 292.

62 The overt political ramifications of this legislation cannot be denied. The feudal service obligations of tenure holders to their landlords which, on the surface, had gradually disappeared during the sixteenth and seventeenth centuries, had, in truth, been transformed into political servitudes - the exercise of political authority by the landowners over their tenants.

The major forms of feudal tenure were military tenure or knightservice, providing the landowner with a standing army, either directly or through scutage payments; socage tenure, providing agricultural production; frankalmoign tenure, ensuring religious salvation; and serjeanty tenure, providing personal servants for the landowner. See Powell Real Property (1977) 41-70; Pollock, supra note 30; Holdsworth An Historical Introduction to the Land Law (1927) 21-9; Baker An Introduction to English Legal History (2nd ed 1979) 193-201. Tenurial holding of land was abolished gradually during the middle ages. The most important legislation affecting the institution of

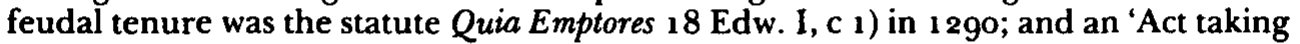
away the Court of Wards and Liveries and Tenures in Capite and by Knight Service and Purveyance and for settling a Revenue upon his Majesty in lieu thereof' (12 Car. II, c 24) in 1660 transformed knightservice and socage tenure into free and common socage. See 1 Washburn The American Law of Real Property (1860) 29-34; Williams, supra note 30 , at $86-91$.

De Tocqueville's laudatory praise of English democracy - that feudalism did not result in the establishment of a caste system in England - is accurate only in the most narrow of perspectives. The obligation of service owed to the lord of the manor was replaced by the more insidious obligation of political fielty. The military authority of the feudal lord had evolved into political influence exercised through the ownership of property, and, until the nineteenth century, property meant land. De Tocqueville L'Ancien Regime (1856) 178. Robertson Electoral Justice (1931) 18, 20; Cannon Parliamentary Reform $1640-1832$ (1973) $1-5$.

63 Gwyer Anson's Law and Custom of the Constitution (5th ed 1922) 111-15; Medley, supra note 53, at 201, 205; Cannon, supra note 62

64 Pollard The Evolution of Parliament (1926) 156; Maitland The Constitutional History of England (1913) 356, 357

$6_{5}$ The result of periodic House of Commons decisions on disputed elections in the boroughs 'over the years was substantially to reduce the size of the borough electorate.' Cannon, supra note 62, at 34; Keir The Constitutional History of Modern Britain Since 1485 (8th ed 1966) 46.

66 Lovell English Constitutional and Legal History (1962) 199, 250. The debate as to the size of the electorate is hardly satisfying. Dalrymple states that the electorate in some particular counties numbered at least 30,0oo. Dalrymple An Essay Towards a General History of Feudal Property in Great Britain (4th ed 1759) 274. Polland estimates that 3000 voters were present at the county election in Norfolk in ${ }_{15} 86$. Pollard, supra note 64 , at 163.

67 Lovell, ibid. Marriot estimates the electorate at 160,000 . 1 Marriot The Mechanism of the Modern State (1927) 477. Cannon, supra note 62, at 290-2.

68 Cannon, supra note 62 , at 41,42 , states:

'In 1715 the total population of England and Wales was some $5^{\frac{1}{2}}$ million: by 1790 it had risen to $8 \frac{1}{2}$ million, and by 1831 it stood at nearly 14 million. - that is, it had increased by $155 \%$. Plumb's estimate of the English electorate at the end of Anne's 
reign was approximately 250,000 . The House of Commons, $1715-54$ suggests a slightly higher figure of 261,000 , of whom 160,000 were county voters. The subsequent volume of The House of Commons puts the county vote in 1754 at about 177,000 , with 105,000 in the boroughs, making a grand total of some 282,000 . Although percentages may suggest a false precision, the electorate seems to have increased in that period by some $8 \%$ against a population increase of some $18 \%$.

'To assess the electorate in the years immediately preceding 1832 is far from easy, since there were several counties where there were no contests or only token ones, and the evidence for many boroughs is similarly fragmentary. There seems little doubt however that the increase in the county electorate was modest ...

'From the figures I have compiled, I would put the increase in the county electorate between 1754 and 1831 at not much higher than $6 \%$. During the same period, the English borough electorate seems to have increased by some $50 \%$. My estimate for the total English electorate in the years immediately before 1832 is some 344,000 , representing an overall increase on 1754 of something like $20 \%$. Since during the same period the total population more than doubled; we may say with reasonable confidence that there was a sharp decline in the proportion of people who had even a formal share in the political life of the nation.'

69 Stout British Government (1953) 202

70 Lovell estimates an electorate, in 1760 , of some 85,000 in the boroughs, of which some 15,000 elected over half the borough members. Lovell, supra note 66 , at 429 . Robertson writes that by the mid-Georgian era, the boroughs 'had generally become the mere vestiges of villages ... mere private possessions, politically speaking, of rich landowners.' Robertson, supra note 62, at 25. 'Only the merest fraction' of the population possessed the vote. Pollard, supra note 2o, at 338 . It has been calculated elsewhere that at the end of the eighteenth century, 11,075 voters elected 257 members of Parliament, and that this narrow electorate was itself controlled by less than 200 more influential landowners. Dickinson, supra note $4^{\circ}$, at 238 . Even where the borough franchise appeared generous, it was often in reality strictly circumscribed; Gatton, which enfranchised all freeholders and 'scot the lot' inhabitants, consisted of an electorate of seven; Tavistock only ten. Marriot, supra note 67 , at 476 . Walcott has estimated that in 1701 over 40 per cent of the boroughs consisted of electorates of less than 100 voters, another 25 per cent had less than $5^{\circ 0}$, and only 12 per cent had more than 1000. Walcott English Politics in the Early Eighteenth Century (1956) 23. An admittedly idiosyncratic sample of various boroughs during the eighteenth century reveals an electorate of 100 in Tregony in $1696 ; 250$ in Abingdon in 1699 and again in 1796; over 1000 in Colchester in $1711 ; 45^{\circ}$ in Carlisle in 1 $712 ; 37$ in Bury St Edmonds in 1 1 18-24; and 100 or fewer in several boroughs, including Appleby and Great Bedwyn. Nottingham's electorate in 1753 was over 2000. Williams The Eighteenth Century Constitution 1688-1815 (1960) $152-70$.

71 Phillips and Jackson Constitutional and Administrative Law (6th ed 1978) 187

72 McKenzie British Political Parties (2nd ed 1963) 2, 4

73 Wright The Law Relating to Landed Estates (1897) 135, 136

74 Pollack, supra note 30 , at 49

75 Powell, supra note 62 at 60 . Coke wrote in 1584 that the ' $[\mathrm{g}] \mathrm{reat}$ part of the land within the realm is in grant by copy.' Heydon's Case $(1584) 3$ Co. Rep., at note 86.

76 1 Rogers History of Agriculture and Prices in England (1866) 693. See Sir Colin Thornton Kenisley, Tradition and change in property ownership, in Denman (ed) Contemporary Problems of Land Ownership (1962). Tuberville argues that no more than 7000 persons owned 80 per cent of the land in England as late as 1876 . Tuberville The House of Lords in the Age of Reform ${ }_{7} 784-1837$ (1958) 407-10. See also Scrutton Land in Fetters (1886) 144-5.

77 Brodrick, supra note 30 , at 166 . Brickdale, writing in 1914 , could say that 'the soil of our country ... will remain for ever what it is at present - chiefly an exclusive luxury of the very rich, and seldom, if ever, enjoyed by any beyond the limited circle of the comparatively well-to-do.' Brickdale Methods of Land Transfer (1914) 207. 
The influence exercised by those who held the political franchise was exacerbated by the archaic distribution of parliamentary seats prior to the nineteenth century. For example, London, with an immense population numbering in the hundreds of thousands, returned four members to the House of Commons in 1801, while 21 Cornish boroughs, each with a population of under 200 , returned 42 members. Lovell, supra note 66, at 427 . Other boroughs, such as Gratton, returned two members out of an electorate of six. Ibid, at 419. Two boroughs, Old Sarum and Dunwich, no longer existed, the former being deserted and the latter having fallen into the sea. Yet both returned members to Parliament, chosen by owners of the land where the boroughs formerly existed as thriving communities. Stout, supra note 69 , at 203 . The burgage boroughs, in which the franchise was allocated to the owners of specific pieces of property, were often 'pocket boroughs,' literally in the pocket of a family or patron who controlled all or nearly all of the enfranchised property. Lovell, supra 66, at 428 , 429. Cannon, supra note 62.

The result of four centuries of propertied voting rights was a form of representational democracy which vested absolute political control in a narrow oligarchy of landowners. One historian has detailed the history of political democracy in the late eighteenth and early nineteenth centuries in graphic terms, describing the House of Commons of over 500 parliamentarians of whom 326 were returned by 182 individuals. Robertson, supra note 62, at 34-8. Although mathematical accuracy is an unattainable object, similar figures are given by others. See 2 Gneist The History of the English Constitution (2nd ed 1889) 447.

In 1816 , Oldfield calculated that 87 peers controlled the return of 218 English parliamentarians and that 57 peers were responsible for the return of 82 Scottish and Irish members. 6 Oldfield The Representative History of Great Britain and Ireland (1816) 295-9. The influence of commoners was equally pervasive. In 1780, 6000 men were said to have returned a clear majority of the members of Parliament. Marriot, supra note 67 , at 477 . Todd cites evidence prepared in 1865 which compared voting rights based on population (4 votes to the upper class, 32 to the middle, and 64 to the working classes) to the allocation of voting rights based on land ownership $(83$ to the upper classes, 13 to the middle, and 4 to the working classes). 1 Todd Parliamentary Government in England (1887) 26.

78 Under article 18 of the Instrument of Government, The Government of the Commonwealth of England, Scotland and Ireland, and the Dominions thereunto belonging, 16 December 1653, the qualification for the county franchise was extended to those who possessed or owned real or personal property of a value of $£_{2} 00$. The borough franchise was left to custom. See Gardner, Constitutional documents of the puritan Revolution, in Medley, supra note 53, at 311. Gough has described the conflict between the radical and conservative factions of the Levellers. The latter regarded 'the safeguarding of property as one of the primary objects of government, and ... insisted on the historic principle that the franchise should be extended to property owners.' Gough Fundamental Law in English Constitutional History (1961) 1 13, 114 . MacPherson has described the numerous franchise proposals considered by participants in the seventeenth-century revolutionary movements. MacPherson The Political Theory of Possessive Individualism (1962) 107-59. See also Cannon, supra note 62, at 1-23.

Reform of the franchise was abandoned upon the restoration of the monarchy in 166o. Keir, supra note 65 , at 231 .

792 Will Iv, c 45

8o For example, the franchise was extended to non-occupying freeholders of an annual value of ten pounds; to holders of land by copyhold or any other tenure for life or lives, or any longer estate, of the same annual value; to leaseholders for any term originally of greater than sixty years with an annual value of ten pounds, or of a term of twenty years with an annual value of fifty pounds; and to persons occupying as tenants-at-will who were liable for rent of at least fifty pounds. Ibid, ss 18-20.

81 Keir, supra note 65 , at 401

82 Butt The Power of Parliament (1968) 59. Lovell, supra note 66, at 471 . Turberville relates 
that some Members of Parliament objected to the enfranchisement of fifty-pound tenants-at-will because it would favour the landlords. Turberville, supra note 76 , at 268, 407 .

83 See 1 May The Constitutional History of England (1911) 302-8. In the appendix to Cox and Grady Registration and Elections, Parliamentary and Municipal (1880), twenty-four statutes ranging from the House Occupiers' Disqualification Removal Act, 41 Vict., c 3, to the Property Qualification Abolition Act, 21 \& 22 Vict., c 26, are set out in full. The Representation of the People Act, 1918, 7 \& 8 Geo. v, c 65, repealed over one hundred earlier statutes.

8430 \& 31 Vict., $c 102$

$8548 \& 49$ Vict., c 3

86 See Laski, The personnel of the English cabinet $1801-1924$ (1928) 22 Am. Pol. Sci. Rev. 18, 19. Lovell, supra note 66, at $47^{2}-7$. Jennings The British Constitution (1942) 5 . Even Bagehot, who favoured restricting the electorate, complained in 1888 ' $[\mathrm{t}]$ hat Parliament leans too much to the opinions of the landed interest.' Bagehot The English Constitution (5th ed 1888) 163 . Turberville, supra note 76 , at 407 . Butt, supra note 82 , at 40. Marriot, supra note 67 , at 482,483 . Guttsman has collected detailed statistical data describing the continued influence of the landed interests during the nineteenth and twentieth centuries. Guttsman, supra note 1, at $75^{-108}$. One should note, however, that such influence was not limited to land owners; it extended as well, to the church. See Somerville and Ross Irish Memoirs (1925) 28.

87 Todd, supra note 77, at 12-26; Turberville, supra note 76, at 407; 2 Taylor The Origin and Growth of the English Constitution (1904) 530; Gneist, supra note 77, at 455-75

88 Representation of the People Act, 1918, 7 \& 8 Geo. v, c 64; Representation of the People Act, 1928, 18 \& 19 Geo. v, $c 12$

$893_{1}$ Geo. III, C 31 . By contrast, land as a political commodity, withdrawn from the regular channels of commerce, did not prevail in the American colonies. Although the United States began with the same traditions, democratic ideals combined with an abundance of land quickly produced reform. See Konig, Community, custom and the common law: Social change and the development of land law in seventeenth-century Massachusetts (1974) 18 Am. J. Legal Hist 137. De Tocqueville, Democracy in America (Mayer and Lerner eds, 1966) 696. The original colonies began with English electoral traditions, but possibly by the end of the eighteenth century, and certainly by the middle of the nineteenth, property qualifications were abandoned in most states. Dietz In Defence of Property (1963) 146, 147. Nonetheless, even in America, vast tracts of land were held by the very wealthy, and it has been argued that in 1787 'property qualifications left perhaps ... a third of the white, male population disenfranchised.' Parenti Democracy for the Few (1977) 50-1. Taft has suggested that of a population of 4,000,000 in the 13 colonies, only 150,00o were qualified to vote. Taft Popular Government (1913) 13.

No explicit constitutional protection of a universal right of suffrage exists in the United States, and the courts have consistently refused to invoke the constitutional guarantee of a republican form of government as the foundation of a constitutional protection of the right to vote. Pope v Williams 193 U.s. 621 (1904); Luther v Borden $4^{8}$ u.s. (7 How.) 1 (1849); Baker v Carr 369 u.s. 186 (1962). Voting rights have been protected under the equal protection clause of the Fourteenth Amendment (see Harper $\checkmark$ Virginia Board of Elections 383 U.s. 663 ( 1966); Kramer v Union Free School District No. 15 395 U.S. 621 (1969)), and the First Amendment 'political expression' doctrine has also been referred to in support of the franchise. Kusper v Pontikes 414 U.s. 51 (1973).

Nonetheless, vivid examples of property qualifications, indeed of land ownership, as a prerequisite to the franchise in elections for certain limited purposes have recently been sustained by the Supreme Court. See Salyer Land Co. v Tulare Lake Basin Water Storage Co. 410 u.s. 719 (1973). Compare Hill v Stone 95 S.Ct. 1637 (1975) (property qualification held invalid in the case of a general obligation bond election).

go 31 Geo II, C 31 , ss 20, 24

91 Ibid 
92 In Upper Canada persons who had sworn allegiance to a foreign state, whose deeds had not been registered within three months of an election, or who had not been in possession of land or in receipt of its income for twelve months prior to an election were disqualified. 40 Geo. III, c $3 ; 4$ Geo. c 3 . A university franchise was established in 1820 by 6o Geo. III, C 2, s 4; 1 Geo. IV, C 2.

In Lower Canada, persons who were not in receipt of income from land for six months prior to the election, fraudulent grantees, and persons guilty of perjury were disenfranchised. 2 Geo. IV, c 4; 5 Geo. IV, c 33.

933 \& 4 Vict., c 35, s 27

9412 Vict., $c 12$

9516 Vict., c 153 ; 18 Vict., c $7 ; 18$ Vict., c 87

96 c.s.c. 22 Vict., c $6, \mathrm{~s} 4$

97 See Beck The Government of Nova Scotia (1957) $257,258$.

98 S.N.B. 18 Vict., C 37

99 Section 41 of the British North America Act, 1867, 30 \& 31 Vict., c 3 , provided for the continuation of provincial franchise qualifications until federal legislation was enacted. The provincial franchise prerequisites were hardly enlightened. See Kennedy The Constitution of Canada (1922) 391; Beck, supra note 97; Schindeler, Responsible Government in Ontario (1969) 93, 94; Donnelly The Government of Manitoba (1963) 72, 73; 1 Keith, Responsible Government in the Dominions (2nd ed 1927) 392-5.

100 Ward The Canadian House of Commons, Representation (1950) 212 ; Brady Democracy in the Dominions (1958) 68

101 Ward, ibid, at 213

102 Dawson The Government of Canada (5th ed 1970) 321 ; Kennedy The Constitution of Canada $1534-1937$ (2nd ed 1938) 387; Keith, supra note 99, at 393

10348 \& 49 Vict., c 40; see Mallory The Structure of Canadian Government (1971) 181 . Prior to $188_{5}$ the federal parliament had enacted a number of temporary election acts, all of which had retained the provincial franchise: 34 Vict., c 20; 35 Vict., c 13; 36 Vict., c 27; 37 Vict., c 9. The Electoral Franchise Act of 1885 repealed the previous acts and, with the exceptions of British Columbia and Prince Edward Island, instituted uniform property qualifications throughout the country.

104 In these provinces, more liberal vested rights of franchise existing as of $20 \mathrm{July} 188_{5}$ were retained.

105 See Electoral Franchise Act, 48 \& 49 Vict., c 4o, $s 2$.

106 Ermatinger Canadian Franchise and Election Laws (1886) 6-9. Other significant franchise qualifications of an extremely complicated system of electoral prerequisites included: attainment of the age of majority; British citizenship; and either ownership of real property worth $\$ 200$ in any town or $\$ 300$ in a city or tenancy rights at a monthly rental of at least $\$ 2$, a quarterly rental of at least $\$ 6$, a half-yearly rental of at least $\$ 12$, or an annual rental of at least \$20. Other franchise qualifications included occupancy of real property; residence and income from trade, office, calling, or profession; and family relationship. Similar franchise requirements were imposed in the counties. Electoral Franchise Act, 48 \& 49 Vict., c 4o, ss 3, 4 .

107 Legislative authority over 'Property and Civil Rights in the Provinces' is vested in the provincial governments under s 92 (13) of the British North America Act, 1867, 30 \& 31 Vict., c 3 .

108 Re North Perth Hessin v Lloyd (1891) 21 O.R. 538, 541, 542. But see Re Simmons and Dalton (1886) 12 O.R. $5^{\circ}, 5_{17}$ (suggesting that the right to vote was a mere civil right within provincial jurisdiction and beyond federal legislative competence).

10961 Vict., $\mathrm{c} 14$

$1107 \& 8$ Geo. v, c 34; $7 \& 8$ Geo. v, c 39 .

111 Dominion Elections Act 10 \& 11 Geo. 46 , s 29. The right to vote is now dependent upon citizenship. Canada Elections Act s.c. 1970, c 14 (1st Supp.); as amended by s.c. $1973-4, c_{5}^{1} ; 1974-5-6, c 66$; s.c. 1977-8, c 3 . Vestiges of the property qualification remained until $194^{8}$ in respect of the disenfranchisement of residents of charitable institutions in New Brunswick, Ontario, and Nova Scotia. See Ward, supra note 10o, at 
233-7. Mill had argued, decades earlier, for the disenfranchisement of those 'in receipt of parish relief.' Mill Considerations on Representative Government (McCallum, ed, 1946) 213-15.

Property qualifications for membership in the House of Commons, originally entrusted to the provinces, had been abolished in 1874 by 37 Vict., c $9, \mathbf{s} 20$.

112 Pollard, supra note 64, at ${ }_{156}$. McKinley The Suffrage Franchise in the Thirteen English Colonies in America (1905) 8, 9. But see 4 Co. Inst. at 4, 5; Nairn v St. Andrews University [1909] A.C. 147 (women disentitled to vote at common law). 12 Halsbury Encyclopedia of the Laws of England (1910) 140; Brown v Ingram 7 Sess. Ca. (3rd Ser.) 281 (Scotland).

One advocate of reform suggested in 1797 that it has never been in the contemplation of the most absurd theorists to extend the elective Franchise to the other sex.' 33 Fox Parliamentary History cols 726, 727, cited in Bailey, supra note 6o, at 66.

113 Catharine v Survey, cited in Olive v Ingram (1739) 7 Mod. 263, 264; Coates v Lisle 14 Jac. 1 , cited in Olive v Ingram; Holt v Lyle (1606), 4 Jac. 1, cited in Olive v Ingram, at 267, 271

114 Cleverdon The Woman Suffrage Movement in Canada (2nd ed 1974) 214, 215

115 Philips and Jackson Constitutional and Administrative Law (6th ed 1978) 187

116 Anelay v Lewis (1855) 17 C.B. 316,328

117 Elliot A Practical Treatise on the Qualifications and Registration of Parliamentary Electors (1839) 14

118 1 Blackstone Commentaries on the Laws of England (18th ed 1829) 173, at note 62

11920 Geo. III, C 17 , S 12

120 See Chorlton v Lings (1868) L.R. 4 C.P. 374; 1 H. \& C. (women not entitled to vote in boroughs); Chorlton v Kessler (1868) L.R. 4 C.P. 397; 1 H. \& C. 42 (women not entitled to vote in counties); Rogers Elections, Registration and Election Agency (13th ed 1880) 180. The Reform Act, 1832, 2 Wm. c 45 referred to 'male persons,' and the Representation of the People Act, 1867, 30 \& 31 Vict., c 102, used the word 'man.' It should be noted, however, that women did not, merely through ownership of land, acquire the privilege of sitting in Parliament. Maitland, supra note 64 , at 364 .

121 Pollard, supra note 64 , at 165

122 Holmes, supra note 5 , at 384 . Cf Lovell, supra note 66 , at 426 . Austin has said that land 'is erected into a legal or fictitious person.' Austin Jurisprudence (3rd ed 1872) 847.

123 Anson, The franchise bill (1885) i Law Rev. 25, 27

$124(1855) 17$ C.B. 316

125 Ibid, at 325

126 Gough, supra note 78 , at 178 . Gough in another context refers to the Statutes of Uses (1536), De Donis Conditionalibus and Quia Emptores as striking 'close to the heart of what ... one might have thought would have been inviolable - the individual's rights of property, and even that most "real" of all kinds of property, property in land.' Ibid, at 25.

127 'It is the beliefs which are so much a matter of course that they are rather tacitly presupposed than formally expressed and argued for, the ways of thinking which seem so natural and inevitable that they are not scrutinized with the eye of logical self-consciousness, that often are most decisive of the character of a philosopher's doctrine, and still oftener of the dominant intellectual tendencies of an age.' Lovejoy The Great Chain of Being: A Study of the History of an Idea (2nd ed 1964)

128 (1704) \& Sak. 19; 1 E.R. 417 . Holt CJ dissented in the case, the majority holding that the common law judges had no authority where matters of Parliament were at issue. See Sugden The Law of Property as Administered by the House of Lords (1840) 18

129 Ashby $v$ White, ibid, at 20

130 Ibid. S.A. de Smith describes the right to vote as 'in the nature of a proprietary right.' De Smith Constitutional and Administrative Law (3rd ed 1977) $23^{8}$

13114 St. Trials 695, 792

132 Mayne, supra note 36, at 1, 2; Williams Principles of the Law of Real Property (14th ed 1882) 7; Kersley Goodeve's Modern Law of Personal Property (9th ed 1949) 2. 'In early law, property was deemed "real" if the courts would restore to a dispossessed owner the thing itself, the "res," and not merely give compensation for the loss.' Megarry and Wade The Law of Real Property (4th ed 1975) 10. 
133 Heuston Essays in Constitutional Law (1961) 81

134 Fry, supra note $5^{1}$, at 16 . 'The proof of title often takes a considerable time.' Wright, supra note 73 , at 2 .

1357 \& 8 Will. III, c 25, s 7; 2 \& 3 Will. Iv, c 45, s 23. Underhill The Law of Mortgages (6th ed 1910) 451,452 . See Wallis v Birks $(1870) 5$ L.R.C.P. 222 (curate of parish as holder of equitable interest in freehold of church entitled to vote). Baxter $v$ Newman (1845) 14 L.J.C.P. 193, 197 (person seized in equity to have the same right to vote as if he had the seizen in law).

136 Shaw v Foster (1872) L.R. 5 H.L. 321 ; Lysaght v Edwards (1876) 2 Ch. D. 499; Paine v Muller (1801) 6 Ves. 349 ; 33 E.R. 1088.

137 Leader, supra note 58 , at 10 . Once the contract is entered into, the vendor is said to be a mere trustee for the new 'owner,' and if he relinquishes possession he loses the right to vote. McPherson Election Law of Canada (1905) 97. Anelay v Lewis (1855) 17 C.B. 316 ; 139 E.R. 1094 (purchaser of land not in actual possession prior to conveyance not entitled to vote); Murray v Thorniley ( 1846 ) 2 C.B. 217 ; 135 E.R. 927 (grantee of rent charge entitled to vote only if in actual receipt of rent); $R$. v Cawthorne [1930] 3 w.w.R. 373; [1931] 1 D.L.R. 317 (tenants who are not 'purchasers' not entitled to vote); Perry v Morley (1911) 16 W.L.R. $691 ; 16$ B.C.R. 91 (holder of an unregistered agreement for purchase of land not entitled to vote).

Long after ${ }^{1696}$, legislation was enacted which required six months' actual possession or receipt of rents to qualify freeholders to vote ( 2 Will. IV, C 45, s 23); and still later, an act was passed which abolished the right of trustees to vote whether in actual possession or not ( 6 Vict., $c_{1} 18, s_{14}$ ).

138 Ermatinger, supra note 106, at 10; Rogers Laws and Practice of Elections, Election Committees and Registration (9th ed 1859) 33. Others have suggested that a purchaser could not vote unless the purchase money was paid. Elliot, supra note 117, at 61-4.

139 The question of the eligibility of the mortgagor in possession was much discussed in the latter half of the eighteenth century, and seems to have been definitely settled after the Bedfordshire and Buckinghamshire cases, $178_{5}$, which decided, 'that the interest upon a mortgage, the mortgagor still being in possession, is a charge upon the estate within the meaning of the Statute ( $8 \mathrm{Hen}$. vI, 7$)^{\prime}$ '; and that if it was such as to reduce the value of the estate to less than 4 os per annum, 'it does not invalidate the vote.' In the same year there was a case of by no means so decided an authority but shortly afterwards a statute was passed confirming the former decisions.' Turner, The Equity of Redemption, Cambridge Studies in English Legal History (1931) 184.

140 Burgess v Wheate (1759) i Eden. 177; 28 E.R. 652. The same benefits were extended to mortgagors who, from the sixteenth century, had been granted equitable relief on default - a right in equity which by the latter half of the seventeenth century had been described as 'an equitable right inherent in the land ... of such consideration in the eye of the law, that the law takes notice of it and makes it assignable and devisable.' See Anon, (1557-1602) Cary 1, 2; Bacon v Bacon (1639) Toth. 133; 21 E.R. 146. Simpson cites Bodenham $v$ Halle $(1456)$ Seldon Society, vol 10 , at 137 as the earliest known case of equitable relief afforded to mortgagors. Simpson An Introduction to the History of the Land Law (1961) 224, 227. In Coote A Treatise on the Law of Mortgages (4th ed 1880) 15 relief in equity is traced to Langford $v$ Barnard (1594) Toth. 134.

The quotation is from Pawlett v Att.-Gen. $(1657)$ Hardres $46_{5}, 469 ; 145$ E.R. 550; Thornborough v Baker (1675) \& Ch. Ca. 284. In 1738, Lord Hardwicke claimed that 'An equity of redemption has always been considered as an estate in the land ... the person, therefore, entitled to the equity of redemption is considered as the owner of the land, and a mortgage in fee is considered as personal assets.' Casborne v Scarfe (1738) 1 Atk. 603,$605 ; 26$ E.R. 377.

$1417 \& 8$ Will. III, C 25. Turner, supra note 139 , at 103,185

142 Turner, supra note 139 , at 155 . By 1867 Cockburn $\mathrm{CJ}$ in $R \vee$ Baker could say that the commissioners are not bound to enquire whether the legal estate is in him. They find him in possession of the estate, and he "hath or holdeth" the estate and thereby satisfieth the terms of the Statute of Henry vi.' $R$. v Baker (1867) L.R. 2 Q.B. 621.

The protection of social status, class, and political identity may provide an explana- 
tion for the 'anomalous' anti-forfeiture doctrine affording relief from consensual obligations. See Michelman, A comment on some uses and abuses of economics in law (1979) $4^{6}$ U. Chi. L.R. 307, 312. Duncan Kennedy has written an invaluable essay in which he has commented on the role of mercy in legal doctrine: Form and substance in private law adjudication (1976) 76 Harv. L.R. 1685 .

143 Sugden Vendors and Purchasers ( 11 th ed 1846) 343; Scriven, supra note 51, at 617; Twining v Morrice 2 Bro. Ch. Rep. 330; Sir Harry Hicke v Philips Prec. Cha. 575

144 See Hinton v Hinton (1855) 2 Ves. Sen. 631, 638; 28 E.R. 4 o6.

145 Musgrave v Dashwood (1688) 2 Vern. 63; 23 E.R. 650. See Holdsworth, supra note 62, at 16-18, 42-5.

146 1 Spence Equitable Jurisdiction (1882) 646; Anon, 2 Freem. 123; 22 E.R. 1100.

One explanation for the specific enforcement of a class of contracts which was significantly broader than the class which involved a transfer of the franchise was the influence of the Statute of Frauds ( 29 Car. II, c 3) which from 1677 onwards proscribed the enforcement of parol contracts for the sale of land. Copyhold land came within the purview of the statute. Scriven, supra note 51 , at 262 . Courts of Equity soon created techniques which enabled them to recognize contracts which the statute deemed unenforceable at law, the most famous of which is the doctrine of part performance. This equitable doctrine could be applied, however, only in respect of those contracts of which a Court of Equity would entertain, or in the opinion of some, grant a suit for specific performance. The Statute of Frauds thus created an overriding incentive to expand equitable jurisdiction to award performance of a wide range of contracts relating to land, notwithstanding that political rights were not necessarily at issue. Rink v March [1921] 1 w.w.R. 919 (doctrine of part performance applies to contracts in respect of which a court would order specific performance). See also Sarbit $v$ Hanson and Booth Fisheries Can. Co. [1950] 4 D.L.R. 34; reversed on other grounds [1952] 2 D.L.R. 108; Lavery v Pursell (1888) 39 Ch. D. 508, 518.

In McManus v Cooke (1887) 35 Ch. D. 681,697, it was held that the doctrine of part performance applies to contracts in respect of which a court would entertain a suit for specific performance. Some authorities take a narrower position - that the doctrine applies only to contracts 'concerning land' or 'relating to land,' but this view has not been accepted. See Britain $v$ Rossiter (1879) 11 Q.B.D. 123, 129, 131, criticized in Williams The Statute of Frauds (1932) 239; Maddison v Alderson (1887) i Mac. \& G. 572; 41 E.R. ${ }^{1387}$. Fry, supra note 51 , at 283 , states that the doctrine applies 'to all cases in which a Court of Equity would entertain a suit if the alleged contract had been in writing.' Spry concurs in this opinion, citing numerous Australian authorities to that effect. Spry, supra note 23 , at $237,238$.

147 See Weymouth, 3 June 1714; Middlesex, 2 Peck. 23 cited in Rogers The Law of Elections (13th ed 1880) 203 .

$1487 \& 8$ Will III, c 25, s 7, properly cited as 'An Act for the further regulating Elections of Members to serve in Parliament, and for the preventing of irregular proceedings of Sheriffs and other officers in the electing and returning of such Members.' The act was later amended by 6 Geo. II, C 23 , and by 53 Geo. III, C 49 (extending the act to devisees).

149 Ibid

150 See Rogers, supra note 147 , at 204 .

151 Robertson, supra note 62, at 22; 1 Porrit History of the Unreformed House of Commons: Parliamentary Representation before 1832 (1903) 22, The practice was apparently condemned, but for centuries the dilatory process of electoral reform was directed at even more disturbing forms of political influence. Dickinson, supra note 40, at 114 .

152 Marshall v Bown (1845) 7 Man. \& G 188; 14 L.J.C.P. 129

153 (1846) 2 C.B. 84; 15 L.J.C.P. 133; Beswick v Aked (1846) 2 C,B, 156; 15 L.J.C.P, 145; Beswich v Ashworth (1846) 2 C.B. 152; 15 L.J.C.P. 145; Rawlins y Bremner (1846) 2 C.B. 166; 15 L.J.C.P. 145

$154(1846) 2$ C.B. $122 ; 15$ L.J.C.P. 134

155 See Riley v Crossley (1846) 2 C.B. 146; 15 L.J.C.P. 144; Thorniley v Aspland (1846) 2 C.B. $160 ; 15$ L.J.C.P. 145 . 
156 Lewin The Law of Trusts (7th ed 1879) 95; Anson, supra note 123; Platamone v Staple (1815) G. Coop. 250; 35 E.R. 548 (conveyance of rent charge to qualify transferee for seat in Parliament injoined); Birch v Blagrave (1755) Amb. $264 ; 27$ E.R. 176 (conveyance to daughter in order to disqualify father from holding office of sheriff of London set aside).

157 Ashworth v Hopper (1875) 1 C.P.D. 178, 179. In Drewe v Hanson (1802) 6 Ves. Jun. 675; 31 E.R. 1253 Lord Eldon referred to a case of Shirley v Davis where a purchaser was compelled to take property which was supposed to be in Essex but in fact was situated in Kent, notwithstanding that 'the purchaser was told he would be made a Churchwarden of Greenwich, and though his object was to be a freeholder of Essex.' Claims of vendors seeking specific performance of land contracts have been viewed harshly where inadequacies of title have been at issue, perhaps on the ground that if the purchaser's motive is political identity, a forced sale of a non-enfranchised estate even with compensation is entirely inappropriate. Hasley v Grant (1806) 13 Ves. Jun. 73; 33 E.R. 222.

158 Ashworth v Hopper, ibid, at 183 . However, Coleridge J remarked that the landowner had not succeeded in retaining the legal right to forfeit the title of the trust beneficiaries if they sold contrary to his instructions. Ibid, at 189 .

$159(1875)$ 1 Ch. D. 160 (C.A.)

160 Ibid, at 166

161 Plucknett English Constitutional History (11th ed 1960) 562. Williams argues that one need only have had to buy up a majority of the burgage tenements to attain absolute political control of a particular borough. Williams, supra note 70, at 153 . Gwyer, supra note 63, at 107. 'A seat was as much a marketable commodity in the eighteenth century as an advowson in the nineteenth ... the value of a seat was estimated at over $£_{7}, 000$.' Marriot, supra note 67 , at $\mathbf{4 7 8}$. May describes the right of property in enfranchised property, capable of sale and transfer as not being different from any other property. 1 May Constitutional History of Britain 337 (1889).

It is not at all startling to discover in the years after initial attempts at electoral reform that the incidence of tenancies-at-will rose substantially; for the grant of tenancies for a fixed term did not allow the landlord to exercise political control over his tenants, while the transfer of an indeterminate leasehold interest enfranchised the lessee while ensuring electoral influence in the hands of the landowner, who could simultaneously dispossess and disenfranchise his tenant if his vote was not cast as directed. Brodrick, supra note 30 , at $201,202$.

162 Herbert v Saint Michel (1910) 18 Rev. de Jur. 228

163 Langlois v Baby (1863) $10 \mathrm{Gr}$. 358; (1864), 11 Gr. 21 ; Emes v Barber (1869) $15 \mathrm{Gr}, 679$

164 Namier estimated that not more than one out of twenty voters was free of the influence of the landed gentry in the exercise of his vote. Namier The Structure of Politics at the Accession of George III (2nd ed 1957) 166.

165 O'Leary Elimination of Corrupt Practices in British Elections $1868-1911$ (1962) 62. One example is given of 37 tenants of the Duke of Newcastle who, in 1831 , were quickly evicted when they voted against his wishes, and one suspects that their future electoral behaviour would not be as autonomous. Turberville, supra note 76 , at 250 . In the same year the Marquis of Exeter, after evicting those tenants who voted contrary to his dictates, threatened to evict even those who did obey his commands unless they evicted their subtenants. Ibid. In 1860 the landlord of the Cavray Estate in Cardiganshire wrote to his tenants as follows: 'I feel myself morally bound to set before you two alternatives and you are at liberty to choose for yourself, namely, to attend our Church services with your family and thus support its principles, or otherwise (if your conscious will not allow you to comply with my request) you must quit the farm you hold from me.' Cited in Denman Studies in Land Economy, The Place of Property (1978) 55. One result of the Reform Act in 1832 was to perpetuate the economic and political servitudes inherent in a society which tied the franchise to property ownership:

'The Act of Henry vi which created the 4os. county franchise introduced a new motive for letting farms on lease which has not received sufficient attention. It was held that a lease for life constituted a freehold, which, if above the value of $4^{\text {os., }}$ carried 


\section{UNIVERSITY OF TORONTO LAW JOURNAL}

with it a vote for the county. As English tenants have always been wont to follow the politics of their landlords, the multiplication of such freeholds became a ready source of political influence ...

-... a new and powerful motive for refusing leases was created by the Reform Act of 1832. Under the so-called 'Chandos clause,' or section 20, of that Act, every tenant of a farm, paying a rent of $\mathfrak{f}_{5}$ o or upwards, for the first time acquired the county franchise. Thenceforward the political influence of landlords was multiplied by the votes of their farm tenants, and, in order to maintain that influence, it was thought necessary to keep farm-tenants in a state of dependence by letting farms only from year to year.' Brodrick, supra note 30 , at $201,205$.

Even before the 1832 enfranchisement of the easily manipulated tenants, the county electorate was controlled by landed interests:

'The two seats in each county were usually in the hands of the great landed families, aristocratic or otherwise. The vulgar arts of bribery founded in the boroughs were inappropriate among the gentlemen who dominated the affairs of the countryside. "Influence," of course, there was, but it was the social and economic influence of landed magnates over their relations, their servants, their tenants, their shopkeepers; of patrons living over their incumbents; of Lord Lieutenants over the J.P.'s; of aristocrats and gentry over their social inferiors.' Williams, supra note 70 , at 153 . This authority has been described as a kind of 'feudal sway' in Oldfield, supra note 77 , at 285 .

166 Walcott, supra note 70 , at 10 ; Cannon, supra note 62 , at 246,247

167 See Wigmore The Australian Ballot System (2nd ed 1889) 10-14; Plucknett, supra note 161 , at 573

168 Ballot Act, $1872,35 \& 36$ Vict., c 33

169 Hanham Elections and Party Management (1959) 267. See Dickinson, supra note 40 , at 289.

170 See Morris Parliamentary Franchise Reform in England from 1885 to 1918 (1927) ch 2, 9 . Abolition of plural voting was a fundamental tenet of the Chartist platform during the nineteenth century. Hovell The Chartist Movement (1918) 161; Ross Elections and Electors, Studies in Democratic Representation (1955) 38.

171 See 1 Henry v, $c 1$; 10 Henry vi, c 2; 14 Geo. III, c 58 .

172 Mill, supra note 111, at 219 . Although Mill favoured the abolition of plural voting in respect of land ownership, he did so only in so far as it would be replaced by plural rights founded upon intelligence and education. Ibid, at 217-2o. One R. Burnett, writing to his principal, the Duke of Newcastle, in 1733 , explained that he had met with thirty or forty freeholders 'who are most of them Duble votes.' Williams, supra note 70, at 149 .

173 Lovell, supra note 66 , at 426 . 'A county election might be continued from day to day as long as voters came to the poll for as many as eleven days.' Courtney The Working Constitution of the United Kingdom (1901) 62. Stout, supra note 69, at 206. 'The poll was liable to be kept open for forty days.' May, supra note 161 , at 350 .

174 Dawson, supra note 102 , at 324

175 Ward, supra note 100 , at 220,221

176 By s.c. 37 Vict., c 9 , ss $92-100$

177 See House of Commons Debates 13 April 1920, $115^{8-9}$; 10-11 Geo. v, c 46, s 57. Dawson, supra note 102 , at 324 .

178 Lovell, supra note 66 , at 427

179 See May, supra note 161 , at 333 . 'A vote was a possession too valuable to be parted with except for a high consideration.' Marriot, supra note 67, at 477. Ross describes numerous cases of direct bribery in the form of payments to individual electors. Ross supra note 170 , at 209.

180 One example is given of a payment of 29 shillings to each of $25^{\circ}$ electors, and in another case, payment in hogs and tin. Williams, supra note 70, at 155-6. In 1701 the 32 voters of Norfolk each received fifty guineas. Walcott, supra note 70 , at 16 .

181 Williams, supra note 70 , at 153

182 One might speculate as to the price paid by the friends of the Earl of Shaftsbury for wasteland, consisting of nothing but weeds and rubbish, to which the valuable right of 
suffrage appertained - the land was worth nothing but for the voting privileges attached to it. Oldfield, supra note 77 , at 54 .

183 Walcott, supra note 70 , at 21

184 Cannon describes the constant appreciation in election expenses reflected in the inflated price paid by contestants in open boroughs for the saleable votes of the constitutents: 'Whereas Thomas Webb, a candidate for Wooton Bassett in 1690 , was reported to have purchased votes at $32 / 6 \mathrm{~d}$ a head, sixty-four years later John Probyn and Thomas Estcourt Cresswell were charged thirty guineas apiece in the same borough.' Cannon, supra note 62 , at 35 .

185 O'Leary, supra note $16_{5}$, at 62

186 Williams, supra note 70 , at 155

187 Hanham, supra note 169 , at 166

188 Cox and Grady Registration and Elections, Parliamentary and Municipal (188o) cxvii

189 Ibid

190 Ibid. Liberal agents kept records showing the sums paid out in bribery. Hanham, supra note 169 , at 266 . Attempts to discourage bribery were almost futile. Taylor, supra note 87 , at 532. May, supra note 161 , at 334 . The offering of payment for votes was said to be an offence at common law. Taylor, ibid, at 469 ; May, ibid, at 329. Stephen, however, states somewhat equivocally that bribery is said to have been an offence at common law, citing no authority in support of that view. 3 Stephen $A$ History of the Criminal Law of England (1883) 252.

In any event legislation was enacted as early as 1695 disallowing elections in cases of bribery ( 7 Will. III, $c_{4}$ ). This was followed by more detailed legislation in 1729 ( 2 Geo. II, C 24), and again in 1809 (49 Geo. III, C 118 ).

191 Hirsh in Social Limits to Growth (1976) develops the concept of 'positional' goods, which are described as goods which signify distinctions among individuals on the basis of social status rather than simple economic wealth. This phenomenon, which describes very nicely the place of votes and contract in law, has been described as 'the importance of the symbolic attributes of goods, and the ways in which rank and status are attached to them ... When relative position is at stake, then the society will and must create new scarcities - that is, new symbols of success to be striven for - at every turn. It matters little what is chosen to signify status differences.' Leiss The Limits to Satisfaction: An essay on the problem of needs and commodities (British edition 1976) xvi.

Rawls has developed a rather different theory, but one which also acknowledges the distinctive nature of certain kinds of goods: 'Those aspects of the social system that define and secure the equal liberties of citizenship ... The basic liberties of citizens are, vaguely speaking, political liberty (the right to vote and to be eligible for public office).' Rawls $A$ Theory of Justice (1971) 61. Rawls argues that the basis for self-respect (status) is not simply one's relative wealth in income, but the publicly affirmed equal distribution of these basic rights - including the right to participate in political life. Ibid, at 544,545 .

1929 Anne, c 5. See Gneist The History of the English Constitution (1891) 658; Taylor The Origin and Growth of the English Constitution (1898) 532, 533. In 1838, long after the doctrine of specific performance had become fixed, the property qualification was reformed to allow candidates to make up their stake in real or personal property. 1 \& 2 Vict., $c 48$. It was not until 1858 that the legal property qualification was abolished in its entirety by $21 \& 22$ Vict., c 26 .

193 Cited in Guttsman, supra note 1, at 68 . Parliamentary attendance, even by the late fifteenth century, was no longer an obligatory burden but had become 'an honour to be welcomed, a privilege to be sought.' Ross, supra note 170 , at 207 . See also Wilkinson, supra note 57 , at 291 .

194 Lovell, supra note 66 , at $4^{26}$

195 Ogg England in the Reigns of James II and William III (1955) 58

196 Cannon, supra, note 62 , at 36

197 In Curtis v Perry (1802) 6 Ves. Jun. 739, 747; 31 E.R. 1285 , Eldon LC openly admitted that a suit to reconvey land given by the plaintiff to his son 'to enable him to sit in Parliament ... was very properly dismissed.' But see Platamone v Staple (1815) G. Coop. 250; 35 E.R. $54^{8}$ (conveyance of rent charge to qualify transferee as a Member of 
Parliament set aside); cf Childers v Childers (1875) 3 Kay \& John 310; 69 E.R. 1126 (conveyance of goo acres of land in order to qualify son as bailiff held enforceable).

198 Newton v Overseers of Crowley $(1846) 2$ C.B. 207 (grant to son-in-law for a nominal consideration held a valid transfer of the vote in the absence of fraud); Newton $\mathbf{v}$ Hargreaves $(1846) 2$ C.B. $163 ; 15$ L.J.C.P. 154 (transfer without consideration of land to enfranchise two sons held enforceable): May v May (1863) 33 Beav. 81; 55 E.R. 297 (conveyance of property in order to enfranchise son held enforceable); Groves v Groves (1828) 3 Y. \& J. 163; 148 E.R. 1136 (conveyance to one brother in trust for another in order to enfranchise the latter held enforceable). But see Brackenbury $v$ Brackenbury (1820) 2 Jac. \& W. $391 ; 37$ E.R. 677.

199 Roberts v Roberts (1818) Dan. 153; 159 E.R. 862 (conveyance to qualify purchaser to hunt under the Game Act, 22 \& 23 Car. II, c 25, 33 held enforceable); Cecil v Butcher (1821) 2 Jac. \& W. $565 ; 37$ E.R. 744 (claim to equitable relief on conveyance to qualify vendor's son to hunt on the Eccleshall estate where deed had been lost, refused). Lord Mansfield noted that the qualification was vested in property, and since a trustee was only a nominal owner, the beneficiary under a trust of land would enjoy the privilege of the hunt. Wetherell $\mathbf{v}$ Hall Cald. 230.

$200(1841) 8 \mathrm{Cl}$. \& Fin. 374.

201 Sugden $A$ Treatise on the Law of Property (1849) 72.

202 Russell v Reed (1629) Toth. 164; 21 E.R. 156 . But see Freeman v Blagrave Bacon's Cases at 11 , cited in Potter Historical Introduction to English Law (1932) 513, where an agreement to confer a knighthood was refused as 'venal and mercenary.'

203 Maitland, supra note 64 , at 82

204 The real property qualification appears to have originated at common law, and in 1415 a freehold ownership in an amount of at least forty shillings was fixed by statute. See Thompson and Merriam Conduct of Juries Including Grand Juries (1882) 20; 4 Blackstone Commentaries 302; 3 Bac. Abr. 751-2; 2 Hawk. P.C., 12; 2 Henry v, c 3; Thomas' Case (1794) 1 Dyer 99; 73 E.R. 218 . The value of the freehold as well as the nature of the required ownership interest varied considerably over time and also from one kind of jury to another. See Samaha Law and Order in Historical Perspective (1974) 48-5o; Hay (ed) Albion's Fatal Tree: Property and Authority and Criminal Law (1977) 30, 31. See also Forsyth, A History of Trial by Jury (1878) 143-5; Moore The Jury (1973) 68.

It was not until 1825 that property qualifications were made uniform. The Juries Act, $1825\left(6 \mathrm{Geo}\right.$. IV, $\mathrm{C}_{5}$ ) ) repealed some 85 statutes and instituted landholding, albeit not landholding as restricted as the franchise qualification at the time, as a prerequisite to jury service. The 1825 property qualifications remained in force until this decade, and notwithstanding that the absolute number of qualified jurors increased through devaluation of money and periodic revaluation of assessments, as recently as $195^{6}$ it was estimated that only one and a half million persons in England could serve as jurors. See Cornish The Jury (1968) 28, 29. Devlin Trial by Jury (1956) 21,22 . Jackson, in an admittedly narrow sampling, found that of 5000 parliamentary electors in a ward in Cambridge before the second world war, only 187 persons qualified for jury service. Jackson The Machinery of Justice in England (7th ed 1977) 487 ; Baldwin and McConville Jury Trials (1979) 88-105.

Jurors, drawn for the most part from the same landed classes as the politically enfranchised, were hardly sympathetic to calls for electoral reform, and in the trial of Daniel Holt in 1793 convicted the accused for publishing calls for expansion of the franchise and for democratization of the electoral process (22 St. Tr. 1189).

205 See Samaha, supra note 204 , at $48-50$.

206 Thayer A Preliminary Treatise on Evidence at the Common Law (1898) 151 at note 3. Devlin, supra note 204 , at 17 .

2075 Geo. II, c 18

208 Cannon, supra note 62 , at 36

20918 Henry vi, c 11 . See Samaha, supra note 204, at 67-94. Taylor, supra note 192 , at 532.

210 Supra note 39

211 Indeed, the purchaser's promissory entitlement was often protected only by property 
rule. Until very recently 'expectation' damages could not, for the most part, be recovered for breach of a contract to sell land. See infra, at notes 225-66.

2123 Weber Economy and Society (1968) 1108

213 Lovell, supra note 66, at 426 . '[M]any men, not freeholders, made large fortunes which they usually applied to the purchase of freehold estates.' Ogg, supra note 195 , at 57 .

214 See Bagehot, supra note 86 , at 164

215 Turberville, supra note 76 , at 427 , citing 2 Early Victorian England (ed Young 1934) at 486

216 Tobin, On limiting the domain of inequality (1970) $13 \mathrm{~J}$. of Law and Econ. 263, 269. Okun, Equality and Efficiency: The Big Tradeoff (1975).

217 Simpson, supra note 140 , at 195 . Ownership of land, which was equivalent to political authority, protected the continued control of political decision-making by the landed aristocracy from the claims of mere wealth acquired through finance or trade. Pollard, supra note 64 , at 156,164 . These habits did not die a quick death. Disraeli, before he became prime minister, was loaned money for the purpose of acquiring Hughenden, for '[a] landless Conservative leader was a contradiction in terms; Disraeli, if he was to fill the position, must possess real estate'. Turberville, supra note 76 , at 420 .

218 See Veall The Popular Movement for Law Reform $1640-1660$ (1970) 270 et seq.

219 Simpson, supra note 140, at 195, 219 . Haskins, supra note 39.

220 Scrutton, supra note 76

221 See infra, at note $24^{\circ}$

222 See infra, at notes $225-66$.

223 Ibid

224 Supra note 135

225 Chancery Amendment Act, 1858, 2 \& 22 Vict., c 27,5 : 'In all cases in which the court of Chancery has jurisdiction to entertain an application ... for the specific performance of any covenant, contract, or agreement, it shall be lawful for the same court, if it shall think fit, to award damages to the party injured, either in addition to or in substitution for such ... specific performance, and such damages may be assessed in such manner as the court shall direct.' The act was repealed by the Statute Law Revision and Civil Procedure Act, 1881, 44 \& 45 Vict., c 59, and by the Statute Law Revision and Civil Procedure Act, $1883,46 \& 47$ Vict., c 49 s 3 , but the jurisdiction to award damages remains pursuant to savings provisions included in those acts through the combined effect of $s 5$ of the 1883 act, the Statute Law Revision Act, 1898, 61 \& 62 Vict., c 22, and the Supreme Court of Judicature Consolidation Act, 1925, 15 \& 16 Geo. v, c 49, s 18. See Sayers v Collyer (1884) 28 Ch. D 103; Leeds Industrial Co-operative Society Ltd. v Slack [1924] A.C. $85_{1}$ (H.L.) Stevenson D.C.J. in error in E.J.H. Holdings Ltd. v Bougie et ux. (1977) 3 Alta. L.R. (2d) 244. Jolowicz has pointed out that the jurisdiction created by the 1858 legislation may have been accidentally repealed in 1974 on the enactment of the Statute Law Repeals Act, 1974, 22 \& 23 Eliz. 2, c 22. Jolowicz, Damages in Equity - a study of Lord Cairns' act [1975] Camb. L.J. $224,228$.

Similar legislation exists in Canada. See Queen's Bench Act, R.s.s. 1965, c 73, s 45, para 9; Judicature Act, R.s.o. 1970, C 228, s 21 ; The Judicature Act, R.s.N.B. 1973, CJ-2 as explained in Bridges Brothers L $t d$. v Forest Protection Ltd. (1977) 72 D.L.R. (3d) 335. The Chancery Amendment Act, ${ }^{8} \mathbf{5}_{5} 8$, is in force in British Columbia by virtue of the Law and Equity Act, R.S.B.C. 1979, c 224, s 2; see Rombough et al. v Crestbrook Timber Ltd. (1966) 55 W.W.R. 577 (B.C.C.A.).

226 See 1 Bonbright The Valuation of Property (1937) 328, 329. While innumerable cases dealing with recovery of damages in sales of goods transactions may be cited as authority for the kinds of loss for which compensation will be granted and for the boundaries of recovery in terms of causation and remoteness, most texts on real property cite Diamond v Campbell-Jones [1961] Ch. 22 as authority for the most fundamental of principles of contract recovery. See Ogus The Law of Damages (1973); Di Castri The Law of Vendor and Purchaser (2nd ed 1976); McGregor McGregor on Damages (14th ed 1980).

227 See Fry, supra note 51 , at 6oo; Todd v Gee (1810) 17 Ves. 273, 278; Blore v Sutton (1817), 
3 Mer. 237, 247-8; Jenkins v Parkinson (1833) 2 My. \& K. 5, 11-12; Nelson v Bridges (1839) 2 Beav. 239. These and a number of additional cases on point are collected and very thoroughly analysed in Harpum, supra note 22 , at $67-73$.

228 In Pomeroy's Specific Performance of Contracts ( 3 rd ed 1926) 903 we find the somewhat paradoxical statement that while 'the amount of compensation may be ascertained upon somewhat the same basis as that upon which damages would be assessed for the same loss ... the motives and principles upon which compensation is allowed are wholly different.' But see Mayne, supra note 36 , at 204 , who argues that 'the compensation was really damages.' As one recent commentator put it, 'The exact relationship between the two remedies is not easy to deduce from the reported cases.' Harpum, supra note 22, at 67.

229 Jurisdiction to award damages in Equity was exercised only rarely, and while of historical interest, it had very little, if anything at all, to do with the enforcement of contractual obligations. See City of London v Nash (1 747) 3 Atk. 512 ; 26 E.R. 1095; Phelps v Prothero (1855) 7 De G.M. \& G. 722, 734; 44 E.R. 28o, 285. Fry, supra note 51, at 6oo; Story Equity Jurisprudence (14th ed 1918) 473-4. Simpson points out that an award of damages would have violated the maxim that equity only acted when the legal remedy was inadequate, but claims that 'there seems to have been no reluctance to make an order for payment of money.' Simpson, supra note 9, at 596 . Holdsworth writes, 'It was not until the eighteenth century that it was settled equity would grant only specific performance if damages were not an adequate remedy.' 1 Holdsworth $A$ History of English Law (7th ed 1956) 457 .

There existed as well inherent equitable jurisdiction to order an accounting of profits irrespective of the loss incurred by the plaintiff. See Parker v McKenna (1874) L.R. 10 Ch. 96, 124 .

230 Todd v Gee (1810) 17 Ves. 273, 278; 34 E.R. 106, 107; Kendell v Beckett (1830) 2 Russ. \& M. 88; 39 E.R. 327 (refusal of claim for return of deposit on contract to sell shares)

231 Clerk and Humphry Sales of Land (1885) 358. It is said, in 2 White and Tudor Leading Cases in Equity (9th ed 1928) 453, that defects in tenure which 'extend to the nature of the property itself cannot be compensated in damages. See also Fry Specific Performance supra note 22, at 527, 528 ; Hick v Phillips (1721) Prec. Ch. 575; 24 E.R. 258; Fordyce et al. v Ford (1794) 4 Bro. C.C. 494; 29 E.R. 1007 ; Drewe v Corp (1804) 9 Ves. Jun. $368 ; 32$ E.R. 644; In Re Ridgeway and Smith's Contract [1901] 2 Ch. 98, 108. But see Price v Macauley (1852) 2 De G.M. \& G. 339; 42 E.R. 903.

232 ( 1776$) 2$ Bl.W. 1078; 96 E.R. 635

233 See Washington, Damages in contract at common law II (1932) $4^{8}$ Law Q. Rev. 9o, 94, 95. Law Reform Commission of British Columbia Report On the Rule in Bain v. Fothergill (L.R.C. 28, 1976). Pounsett v Fuller $(1856)$ i 7 C.B. 660 (damages not recoverable where vendor contracts under mistaken belief that his interest in the property was sufficient); Rowe v School Board for London (1877) 36 Ch. D. 619 (damages not recoverable in case of breach of contract to transfer easement); Sikes v Wild (1861), 1 B.\& S. 593; (1863), 4 B. \& s. 421 .

In 1826 in Hopkins v Grazebrook (1826), 6 B. \& C. 31 , it was held that full contractual damages would be recoverable in a case where the vendor knew of the defect at the time of contracting. This exception to the rule was overruled some fifty years later in Bain $\mathbf{v}$ Fothergill (1874) L.R. 7 H.L. 158, at 207: 'Upon a review of all the decisions on the subject, I think that the case of Hopkins v Grazebrook ought not any longer to be regarded as an authority ... the rule as to the limits within which damage may be recovered upon the breach of a contract for the sale of a real estate must be taken to be without exception. If a person enters into a contract for the sale of a real estate knowing that he has no title to it, nor any means of acquiring it, the purchaser cannot recover damages beyond the expenses he has incurred by an action for the breach of the contract' (emphasis added). Although Horwitz has argued that the expectation interest in contracts was not recognized in any context prior to the nineteenth century, this thesis is not supported by the evidence. Simpson, The Horwitz thesis and the history of contracts (1979) $46 U$. Chi. L.R. 533; Horwitz supra note 20 , at 937. 
234 In an early claim for mesne profits, brought in 1770 in connection with an action for ejectment by a plaintiff seeking compensation for the loss sustained on his dispossession from his land, Gould $\mathrm{J}$ said '[T] he plaintiff in this case is not confined to the very mesne profits only, but he may recover for his trouble, \&cc. I have known four times the value of the mesne profits given by a jury in this sort of action of trespass; if it were not to be so sometimes, compleat justice could not be done to the party injured.' Goodtitle v Tombs (1770) 3 Wils K.B. 118 ; 95 E.R. $96_{5}$. In a later case, Buller J said, of a claim for mesne profits, 'The damages here are as uncertain as in an action of assault. 'Goodtitle $v$ North et. al. (1781) 2 Dougl. 584 ; 99 E.R. $368,369$.

235 (1604) Noy. 142; 74 E.R. 1104 . See also Brig's Case (1624) Palm 364; 81 E.R. 1125 ('Un action sur le case pur losse de benefit de son bargaine').

236 Ibid. The reference to 'country' most likely refers to the county in which the franchise was most closely associated with the ownership of freehold land. Ogg, supra note 195, at 122.

237 Supra note $23^{2}$

238 Bain and Paterson v Fothergill and Hankey (1874) L.R. 7 H.L. 158

239 See Pounsett v Fuller (1856) 17 C.B. 66o; Keen v Mear [1920] 2 Ch. 574. The status of the restriction on contractual recovery in Canada has been thrown into considerable doubt by the recent decision of the Supreme Court of Canada in A.V.G. Management Science Ltd. $\mathrm{v}$ Barwell Developments Ltd. et al. [1979] 2 S.C.R. 43, which, although decided with reference to the Torren's system, or rather the quasi-Torren's system, in British Columbia, is of general applicability. In that case Laskin CJ, speaking for the court, noted recent British Columbia legislation which abrogates the rule and commented disparagingly on its applicability generally in Canada.

The Province of British Columbia in s 33 of the Property Law Act, R.S.B.c. 1979, c 340 , has abrogated the rule and allows recovery for a purchaser's loss of bargain. It should be noted, however, that the legislation says nothing of recovery of consequential damages. The report of the British Columbia Law Reform Commission upon which the section was based clearly contemplates recovery of incidental and consequential damages as well as lost profits. Law Reform Commission of British Columbia, supra note 233 , at $19,20$.

240 Bain v Fothergill, supra note 238 , at 174, 211 ; Locke v Furze (1866) L.R. 1 C.P. 441, 453; Barnes v Cadogan Developments Ltd. [1930] 1 Ch. 479, 488; J.W. Cafe's Ltd. v Brownslow Trust [1950] I All E.R. 894, 896; Day v Singleton [1899] 2 Ch. 320, 329; Phillips v Lamdin [1949] 1 All E.R. 770. This analysis is, however, suspect, as it would be easy enough to require proof of actual intention. See Law Reform Commission of British Columbia, supra note 233, at 13 ; Ogus, supra note 226 , at 303 .

241 Sikes $v$ Wild, supra note 233

242 Bain v Fothergill, supra note 238, at 173; Maitland v Matthews (1915) 8 w.w.R. 274; Di Castri, supra note 226 , at 748

243 Bain v Fothergill, ibid, at 202

244 McCormick Handbook on the Law of Damages (1935) 563,684 argues that Flureau $v$ Thornhill, supra note 232 , was 'one of the first instances of assumption by the judge of control over the damages in contract cases.' See also Horwitz, supra note 20, at 925-6.

245 Mayne $A$ Treatise on the Law of Damages $\left(185^{6}\right)$ 106. Mill has made a similar point in a broader context: 'The ordinary progress of society, which increases in wealth, is at all times to augment the incomes of landlords - to give them a greater amount and a greater proportion of the wealth of the community, independently of any trouble or outlay incurred by themselves. They grow richer as it were in their sleep, without working, risking or economising.' Mill Principles of Political Economy book 5, c 2, para 5 . See also George Progress and Poverty (fiftieth anniv. ed 1929). 358-67.

246 Fuller and Perdue, The reliance interest in contract damages (1936) 46 Yale L.J. 1, 61, 62

247 It is true, as discussed earlier, that the vendor could purchase the first buyer's rights from him, thus sharing the wealth represented by the higher price paid by the second offeror. This, however, does not answer the point that the incentive to breach and thus 
to transfer land to its (objectively) more valued use would be quantitatively reduced by the redistribution of wealth. In addition, the 'negotiated breach' argument, if it can be put that way, must taken into account that, at least in respect of land, the prospective purchaser's expectation of success would have been a virtual certainty. Moreover, negotiations in this two-party paradigm are apt to be extremely protracted and expensive. See Trebilcock, An economic approach to the doctrine of unconscionability, in Swan and Reiter, Studies in Contract Law (1980), at 396.

248 See Harnett v Yeilding $\left(1_{105}\right) 2$ Sch. \& Lef. 549 . The example given by Sir John Romilly MR in Earl of Durham v Legard (1865) 34 Beav. 611 of a man selling his property as a freeholder when in fact he held only by copyhold is a classic illustration of the intersection of the rules relating to specific performance and franchise.

249 In Bain v Fothergill, supra note 238, at 172, the House of Lords could not trace the rule to any case before 1776 .

250 See Norwood v Read (1558) Plowd. 180 . See Horwitz, supra note 231, at 919-23.

251 Crenshaw v Williams 231 S.w. 45 ; 191 Ky. 559 (1921), at 48

$25^{2}$ See Slack v Lockhart (1863) i J.R. (s.c.) I (New Zealand); O'Neil v Drinkle (1908) 8 w.w.R. 937 (Canada); West v Read (1913) 13 s.R. (N.s.w.) 575 (Australia). In the United States the majority of state courts adopted traditional contract damage rules. See McCormick, supra note 244, at 680-3; Corbin Corbin on Contracts (1 st ed i 950) 1098; 3 Sedgewick on Damages (9th ed 1913) 101 2, 1016.

253 Ogg, supra note 195 , at 70

254 'Landowners ... favoured primogeniture since it helped to concentrate ownership.' Veall, supra note 218 , at 60 . Simpson has written that the propertied classes 'realized that primogeniture was the very basis of their whole way of life.' Simpson, supra note 140 , at 253 .

255 Tenures Abolition Act, 1660, 12 Car. II, c 24

256 Whalan, Immediate success of registration of title to land in Australia and early failures in England (1966-7) 2 N.Z.U.L.R. 416, 419. Dicey has argued that disappointment of land reformers during the nineteenth century was caused in part by the reactionism of the legal profession: "legal experts, and certainly English conveyancers, are in no hurry to revolutionize a system which enlists their sympathies and promotes their interests.' Dicey, supra note 33, at 223. See also Simpson, supra note 140, at 253.

257 See Merryman, The inter vivos transfer of land (1978) 26 (supplement) J. of Int. छ Comp. Law 91, at 97-100.

$25^{8}$ 'There is certain to be some price at which the plaintiff would surrender his right to specific performance.' Reiter and Sharpe, supra note 12 at 151.

259 Kronman, supra note 12, at 358-60. A similar view has been expressed in respect of other legal phenomena. See Calabresi The Costs of Accidents (1970); Veljanovski, The economic approach to law: A critical introduction (1980) 7 Brit. J. of Law and Society 158 , 171; Weinrib, Utilitarianism, economics, and legal theory (1980) 30 U.T.L.J. 307, 312-15.

At the very least, the price which things 'have' will obviously depend upon the way in which we ask the question. Kelman, Consumption theory, production theory, and ideology in the Coase theorem (1979) $5^{2}$ S. Cal. L.R. 669; Kennedy, Cost-benefit analysis of entitlement problems: A critique (1981) 33 Stan. L.R. $3^{87}, 4^{\circ 1}-7$. Kennedy has noted the 'non market behaviour' of some classes of persons when faced with the opportunity to sell certain 'goods' with obvious moral, religious, or political attributes: 'Take the issue of the manufacture of napalm by Dow Chemical during the war in Vietnam. The private manufacturing sector could never possibly have bought out the antiwar opposition to that allocation of resources - indeed it is doubtful that it could have bought out one single serious antiwar activist.' Ibid, at 420 .

260 See Weinrib, supra note 259 , at 315 .

261 Denman Origins of Ownership (1958) 144,145

262 Freeman v Blagrave, Bacon's Cases at 11 cited in Potter, supra note 202

263 Fortescue-Brickdale Methods of Land Transfer (1914) 207, described land transfer 
reform as the foundation of social egalitarianism. See also Russet, Inequality and instability: The relation of land tenure to politics, in Dahl Readings in Modern Political Analysis (1968) 151-62.

2641 Mill Principles of Political Economy (5th London ed 1893) 296. One of the duties to which Mill refers is, of course, the franchise, and it was this concept of public duty or trust which was propounded as justification for the open ballot. Only through public exercise of the trust could society assess whether a citizen was fulfilling his public obligation.

265 Calabresi and Bobbit Tragic Choices (1978) 32 . See also Singer, Freedoms and utilities in the distribution of health care, in Dworkin, Bermant, and Brown (eds), supra note 7 , with respect to the market distribution of health services.

The Law Reform Commission of Australia in Human Tissue Transplants (Report No. 7,1977 ) recommended that the sale of human tissue be forbidden by law, resting their judgment in part on the grounds that 'traffic in "human spare parts" is objectionable in itself, and that payment will encourage blackmail, coercion, or duress.' Ibid, at 86 .

266 While the courts may have withdrawn from attempts to monetize the value of political identity not merely in response to intractable complexities of assessment, but also because of the affront to social values which such pricing would have entailed, we should note that the withdrawal was not absolute. In the famous case of Ashby v White et al, discussed at note 128 , the plaintiff, in an action decided ultimately in the House of Lords, recovered ten pounds as damages (in tort) when his vote was maliciously refused by a returning officer.

267 Ogg, supra note 195 , at 56,57 . 'No revolution in the distribution of political power would come about without a redistribution of real property.' Turberville, supra note 76 , at 407 .

268 Maine Ancient Law (1oth ed 1912)

269 Ibid, at 185

270 The absence of explicit constitutional limitations in England and Canada restricting the right of the state to take property was not as remarkable as one might suspect. The protection of property through legal limitations on governmental power was instead carried out through the exercise of political authority by powerful property owners elected by less powerful property owners. The narrow franchise was openly justified on the ground that only through government by property owners could the institution of private property be preserved. The function of government as the guardian of private property was established not by constitutional guarantees but by the restriction of political authority in landowners. See Fellman, Property in colonial political theory (1942), 16 Temp. L.Q. 388, at 399, 40o. See also Hadley Under-Currents in American Politics (1915) 48: 'The first cause for this persistence of property right is to be found in the land policy of the United States .. The immigrant who settled in the western states was offered two things: the vote, and the chance of becoming a landowner ... The opportunity to own farms in freehold made ambitious settlers conservative. Men with a hundred and sixty acres of land were not likely to pass laws which would interfere with the rights of property, and particularly of landed property. The prospect of becoming landowners had the same sort of steadying effect upon men who framed the constitutions of new states in 1820 or 1830 that the fact of already being landowners had upon the men who framed the Federal Constitution forty years earlier.'

271 Kessler, Contracts of adhesion - Some thoughts about freedom of contract (1943) 43 Col. L.R. 629, 640

272 In societies which operate without a market, in which the dominant motive or purpose for an exchange transaction is not merely the realization of profit but 'the main goal is to satisfy social needs even if the profit motive is also incidentally present,' damages will not be the preferred remedy. Treitel, Remedies for breach of contract (courses of action open to a party aggrieved), in 7 International Encyclopedia of Comparative Law $\mathrm{C} 16$, 179 (1976). Gsovski in 1 Soviet Civil Law (1948) 438, 439 has described the Soviet concept of specific performance as follows: '[S]oviet jurists unanimously insist that 
soviet law is governed by the principle of specific performance [which] corresponds to the purposes which the obligation serves under the soviet law ... Since the socialist national economy demands that the flow of goods run along the channels established by the plant, the general rule is that the debtor is not relieved from specific performance by paying damages in money ... Specific performance of such obligations is at the same time the fulfilment of the national economic plan.'

273 Farnsworth, supra note 5, at 1216

274 See Gneist, supra note 60 , at 391

275 One notable example which Holmes immortalized in The Common Law is the imposition of criminal sanctions in cases of breaches of contracts for the carriage of passengers, which was advocated in Macauley's draft of the Indian Penal Code. The explanation of the recommendation was that the palanquin-bearers of India were too destitute even 'to pay damages, and yet had to be trusted to carry unprotected women and children through wild and desolate tracts, where their desertion would have placed those under their charge in great danger.' Holmes, Supra note 5 , at 40,41 . Stephen, Supra note 190 , at 300-2. See also Ahmed Anquilla Bin Hadje Mohamed Sallah Anquilla v Estate and Trust Agencies (1927), Ltd. [1938] A.C. 624, 635 (the breaking of an enforceable contract is an unlawful act).

In addition, while specific performance of employment contracts would not be ordered at law, employers did not need private relief to assist them in enforcing their employees' obligations. Until the Master and Servant Act, 1867, 30 \& 31 Vict., c 141, and the Employers and Workmen Act, 1875, 38 \& 38 Vict., c 13, breach of an employment contract by an employee was a criminal offence under the Master and Servant Act, 1824, 4 Geo. IV c 34. In essence, what we have is specific performance at the hands of only one of the parties to the contract.

276 One possible explanation for criminal laws which generally did not touch upon interference with contractual rights but demonstrated a remarkable concern with and sensitivity to property, was the identity of the architects of the criminal law. Moral and social insult was far more likely to be focused on interference with wealth in the form of property than with wealth in the form of bargains. Dickinson, supra note 40 , at 162 . Hay, supra note 204, at $17-63$.

One's perception of the nature of land and the nature of land transfer must take account of penal legislation first enacted in Canada during the nineteenth century designed to reinforce the 'sanctity of contract': 'Everyone who, knowing of an unregistered prior sale or of an existing unregistered grant, mortgage, hypothec, privilege or encumbrance of or upon real property, fraudulently sells the property or any part thereof is guilty of an indictable offence and is liable to imprisonment for two years.' The Criminal Code, R.s.c. 1970, c c-34, s 345. This section of the Criminal Code originated in Quebec, and its application was limited to that province until 1892 . Section 8 of An Act to amend and explain the Ordinance concerning the registration of Hypothecs in Lower Canada, 16 Vict., c 208, was enacted on 14 June 1853 . The section first appeared in its modern form as $\mathrm{S} 114_{4}$ of An Act respecting the Registration of Titles to or Charges Upon Real Estate, - the Law of Hypothecs, - the Dower and Property of Married Women, - and the Conveyance of Socage Lands, C.S.L.C., 186o, c 37. The preamble to the act stated its purpose as the prevention of losses from secret conveyances of real estate and the elimination of uncertainty and insecurity of title in Lower Canada. The legislation was incorporated into The Larceny Act, R.s.c. 1867, c 164 , ss $92,93,94$, and subsequently into the first Criminal Code, $1892,55 \& 56$ Vict., c 29, ss 372,373 .

Although the section (even though it was coupled to a 'reverse onus' provision in respect of proof of ownership) appears not to have been widely enforced, rare convictions and prosecutions have been recorded. See $R$. v McDevitt (1906) 17 C.c.c. $331 ; R$. v Foreman (1955), 111 C.C.C. 297; $R$. v Lawrence (1950), 9 C.R. 5 .

Perhaps the legislation and the absence of any convictions outside Quebec can be explained by the civilian doctrines of sale and property which are markedly different from those of common law. In $R$. $v$ Lawrence, supra, Barlay J suggests (at 12 ) that 'the 
document was not a mere promise to buy within a specified date, the 10 day period refers not to the sale but to the signing of the deed which will evidence the sale. The signing of the deed was not to create the contract but was to evidence the contract of sale already completed between the parties. The sale itself conveyed the property to the purchaser but for the purposes of registration a .... deed had to be executed.' Marler states 'By the contract itself, the ownership, which is a right, is transferred to the purchaser ... the purchaser is owner of the thing through the contract.' Marler The Law of Real Property (1932) paras 223, 436-43; Castel The Civil Law System of the Province of Quebec (1962) 129-33. Not until 1966 was the Quebec Code of Civil Procedure amended to preclude imprisonment for violation of a civil obligation. c.C.P., Art. 1. The existence of penal sanctions (in the truest sense of the word) to enforce contractual obligations has been criticized by the federal Law Reform Commission, which recognized that the offence, if retained in a revised Criminal Code, ought not to be assimilated to the general law of theft. Law Reform Commission of Canada, Criminal Law, Theft and Fraud (Working Paper 19, 1977) 59.

277 Supra note 246

278 Treitel, supra note $\mathbf{2 7 2}$, at 179 . See Grossfeld, Money sanctions for breach of contract in a Communist economy (1963) 72 Yale L. J. 1326, 1340-1. Farnsworth argues, however, that 'even in communist countries ... breach of contract is not a crime.' Farnsworth, supra note 5 , at 1145,1146 .

279 In recent times the argument has been made that basic human and political rights should be insulated from the market because of 'fundamental considerations of liberty and human dignity.' Schultze The Public Use of the Private Interest (1977) 28. See also Rawls $A$ Theory of Justice, supra note 191.

280 During the eighteenth century the task of assessing damages was left entirely to the jury. '[1]n Courts of Law all the evidence in mercantile cases was thrown together; they were left generally to a jury, and they produced no general principle.' Lickbarrow $\mathbf{v}$ Mason (1787) 2 T.R. 63, 73; 100 E.R. 35, 40. 'The amount to be given was in the discretion of the petty jury; it was in the discretion of the attaint jury whether or not this amount was too great.' Washington, supra note 233. By the middle of the eighteenth century the courts were indirectly but effectively controlling the assessment of damages by the jury through manipulation of the rules of evidence, and the exercise of the power of review in so far as the jury acted in disobedience of the trial judge's charge. Ibid, at 9o, 91 .

A similar practice was followed in the United States. See Horwitz, supra note 20, at 925, 926. One of the more important but often overlooked aspects of Hadley $v$ Baxendale (1854) 9 Ex. 341; 156 E.R. 145, was the enhanced predictability of damages through the increased judicial authority over jury damage assessment. Danzig, Hadley v Baxendale: A study in the industrialization of the law (1975) $4 \mathrm{~J}$. of Leg. Studies 249, 272-4.

281 A point commonly made in cases of specific performance is that one piece of property cannot be identical to another, for at the very least each occupies different places in space. The consequences of spatial uniqueness in an era when canal transport constituted the sole form of transportation were substantial. See Sedtadley Railroad Transportation (1885) 3; Moulton Waterways versus Railways (1926) 110, 119. Road transport was in an abysmal state, and the railways did not flower until the mid-nineteenth century. Jackman The Development of Transportation in Modern England (2nd ed 1962); Dyos and Aldcroft British Transport, An Economic Survey from the Seventeenth Century to the Twentieth (1969); Albert The Turmpike Road System in England 1663-1840 (1972). But see Chartres, Road carrying in England in the seventeenth century: Myth and reality (1977), 3o Econ. Hist. Rev. (2nd series) 73 .

The significance of proximity to a canal was incontravertible. See Sedtadley Railroad Transportation (1885) 159; Danzig, supra note 280, at 259, 260. Turnbull, Pickfords and the canal carrying trade, 1780-1850 (1973) 6 Transport History 5; Pegrum Transportation and Public Policy (1973) 40. As one railway official put it, 'the canals only carry from one point to another, from $A$ to $B$ or $C$, as a rule, whereas railways can carry from $A$ to the 


\section{UNIVERSITY OF TORONTO LAW JOURNAL}

rest of the alphabet.' Moulton Waterways versus Railways (1926) 109. The importance of locale and thus the concept of 'uniqueness' was not restricted to inter-urban markets. One must, in reading the cases, keep in mind that even London did not have an urban mass transportation system until the second half of the nineteenth century. Some " $4 \frac{1}{2}$ square miles held some 425 , 000 people (44 percent of the total population of London at an average density of 149 to the acre). By 1851 this ... area had extended to include ... 9 square miles; it then housed 945,000 people.' Hall, The origins: urban growth in Britain 1801-1939, in 1 Hall (ed) The Containment of Urban Land (1973) 76.

As notable a political and economic observer as Adam Smith has described the transformation of the relevance of differences of geographic situation resulting from efficient and accessible transportation facilities which resulted in 'upon that account the greatest of all improvements.' 1 Smith An Inquiry into the Nature and Causes of the Wealth of Nations (Glascow ed, Cambell, Skinner, and Todd, eds, 1976) 163.

282 Vestiges of the connection between land ownership and political power do, however, remain. For example, after Confederation property qualifications were often imposed on candidates. See Spencer v Farthing (1915) 8 w.w.R. 1186 (Man. C.A.); Falconer v Langley (1899) 6 B.C.R. 444; $R$. v Galloway (1886) 3 Man. R. 297. Similar qualifications were sometimes imposed on voters. In re Kelso Municipal Voters List (1 907 ), 12 B.C.R. 362 (registration under land registration statute necessary to vote); Perry v Morley (1911) 16 W.L.R. $69_{1}$ (holder of an unregistered agreement for purchase of land not entitled to vote); In re Clark (1 go6) 3 W.L.R. 311 (applicant for homestead with first right to obtain interest not entitled to vote). Some remnants of the connection exist even today. See The Municipal Elections Act s.o. 1972, c 95, s 13.

283 At note 21 supra

284 At note 239 supra

285 For example, the contractual entitlement to corporate shares, and, more particularly, the right to sufficient shares to constitute the prospective owner the effective manager of the corporate wealth represented by the assets of the corporation and influence of the office, are specifically enforced virtually as a matter of course. Dobell v Cowichan Copper Co. Ltd. (N.P.L.) et al. (1967) 61 w.w.R. 594 (B.C.S.C.) (injunction restraining disposition of shares by defendant to anyone other than plaintiff); Gilbert $v$ Barron (1958) 13 D.L.R. (2d) 262.

Although the speculative nature of any attempt to assess accurately the pecuniary value of 'control' has been proferred as the underpinning of equitable relief, another equally plausible rationale might be an implicit recognition that the political and social influence exercised by the modern corporation cannot be measured in dollars and cents. See Note, Specific performance of contracts for a controlling interest in a corporation (1935) 49 Harv. L. R. 122; Neef, Equity - Specific performance - Recent trends in the specific performance of contracts to sell securities (1953) $5^{1}$ Mich. L.R. $408,4^{1} 4-16$. Thus it is not at all surprising that the specific performance of a right to obtain corporate securities is now enshrined in legislation. For example, s 87(3) of the Ontario Business Corporations Act, R.s.o. 1970, c 53, reads as follows: 'The right to obtain or reclaim possession of a security may be specifically enforced by specific performance or its transfer enjoined.'

286 University Council of the Vidyodaya University of Ceylon v Silva [1965] 1 w.L.R. 77

287 Supra note 9. Waddams, supra note 2, at 427, 428; Emerald Resources Ltd. v Sterling Oil Property Management, supra note 9, at 647 . The fear that an order for specific performance of a contract of employment would be unworkable was typical of eighteenth-century judges. A common concern was expressed by Fry $\mathrm{LJ}$ in De Francesco v Barnum ( 1890 ), 45 Ch. D. 430 , at 438 : 'For my own part, I should be very unwilling to extend decisions the effect of which is to compel persons who are not desirous of maintaining continuous personal relations with one another to continue those personal relations. I have a strong impression and a strong feeling that it is not in the interest of mankind that the rule of specific performance should be extended to such cases. I think the Courts are bound to be jealous, lest they should turn contracts of service into contracts of slavery; and therefore, speaking for myself, I should lean against the extension of the doctrine of specific performance and injunction in such a manner.' 
288 A related point which provides insight into and reinforces this rationale for the evolution of property rules was the common law's outright denial, except in limited cases which need not concern us here, of damage compensation in cases of contracts of employment for anything but demonstrable economic loss. See Addis v Gramophone Limited [1 19og] A.C. 488; Groom v Crocker [1939] 1 K.B. 194; Sedgwick Elements of the Law of Damages (2nd ed 1909) 103. Hobbs v L.S.W. Railway (1875) L.R. 10 Q.B. 111,122 (inconvenience, annoyance, disappointment not compensible in damages); Hamlin v G.N. Railway (1856), 1 H. \& N. 408; 156 E.R. 1261 (damages not recoverable for injury to feelings). Thus the loss of social stature or the failure to acquire political identity or authority on the purchase of land were not compensable under traditional common law rules. No impenetrable barrier existed to the development of an exception to this rule which would recognize the kind of loss incurred on the failure of a land contract, but the ephemeral nature of social prestige and the risks and uncertainty inherent in the assessment of the value of the political attributes of land combined to nurture the development of property rules rather than common liability rules to protect contractual entitlements.

289 Supra note $\mathbf{2 8 8}$

290 Re an Arbitration between Golomb and Porter E Co. (1931) 144 L.T. 583 , at 588; Withers v General Theatre Corporation [1933] 2 K.B. 536; (1933) 149 L.T. 487 (damages recovered for lost opportunity of enhancing and maintaining reputation); Tolnay v Criterion Film Productions [1936] 2 All E.R. 1625 (damages recovered by playwright for lost publicity). But see Collier v Sunday Referee Publishing Co. [1940] 2 K.B. 647.

291 See Moss v Chesham Urban District Council (1945) 172 L.T. 301.

292 Supra note 288

293 Bertram v Bechtel Pacific Corporation Ltd. (unrep. A6/78, Whang), cited and discussed in Szakats, Wrongful and unjustified dismissal: Damages and compensation, A Case for Reform [1979] N.Z.L.J. 13.

294 [1976] 3 All E.R. 161

295 Ibid, at 166

296 Tippet v International Typographical Union (1976), 71 D.L.R. (3d) 146, 149-150. Other cases evincing a liberal attitude towards non-employment subsidiary losses including relocation expenses and 'intangible but valuable loss of future benefits' have surfaced, leading one commentator to remark, insightfully, that the decisions 'run contrary to the principle of the employer's rights to terminate with notice'. Vos v Security Trust Company Limited (1969) 68 w.w.R. 310; Johnston v Northwood Pulp Ltd. (1968) 70 D.L.R. (2d) 15. Szakats, supra note 293 , describes numerous cases decided by the New Zealand Industrial Court granting compensation for 'distress of mind,' 'hurt feelings,' 'loss of dignity,' 'impairment of reputation,' and the like.

Generally, however, Canadian courts have taken the Addis v Gramophone, Limited decision as gospel. See McMinn v Town of Oakville (1979) 85 D.L.R. (3d) 131. In Abouna v Foothills Provincial General Hospital Board (No. 2) (1978) 83 D.L.R. (3d) 333, the Alberta Court of Appeal held as follows: '[G]enerally speaking, damages are limited in the case of a fixed term contract to earnings which would have been made during the balance of the fixed term, less anything which may be the result of mitigation, or anticipated mitigation; or, in the case of indeterminate hiring, salary for a period amounting to reasonable notice. Damages for loss of reputation in a suit for wrongful dismissal cannot be claimed.'

The Supreme Court of Canada, in Peso Silver Mines Ltd. (N.P.L.) v Cropper [1 1966] S.C.R. $673 ; 58$ D.L.R. (2d) 1 , has affirmed the Addis doctrine (per Cartwright $\mathrm{J}$, at $683-4$ ): 'The learned trial judge awarded the respondent $\$ 10,000$ which represented the balance of his salary for the year ending December 16, 1964. He indicated, however, that he would have fixed the damages at $\$ 6,500$ were it not for the circumstances of the respondent's dismissal, namely that the unsubstantiated allegations of impropriety made against him and the fact of his dismissal so shortly after Charter had taken control of the appellant could not fail to damage his reputation among mining men. I agree with Bull J.A. that the claim being founded on breach of contract the damages cannot be increased by reason of the circumstances of dismissal whether in respect of the 
respondent's wounded feelings or the prejudicial effect upon his reputation and chances of finding another employment'.

A case in favour of awarding compensation for intangible losses is Thurlow $\mathrm{v}$ Alberta Government Telephones 18 March 1963 (unreported), cited in Harrison, Termination of employment (1972) 10 Alta. L.R. 250.

297 Yewens v Noakes (1880), 6 Q.B.D. $53^{\circ}$

298 See Cantol Ltd. v Brodi Chemicals Ltd. et al. (1979) 5 B.L.R. 177; Elsley v J.G. Collins Ins. Agencies Ltd. (1978) 83 D.L.R. (3d) I (s.C.C.) (imbalance of bargaining power may, in the negotiation of a contract of employment, lead to oppression).

299 See Fry, supra note 51 , at 219,386 ; Snell's Principles of Equity (27th ed 1973) 582 ; Flight v Bolland (1828) 4 Russ. 298; 38 E.R. 817 ; Cooke v Gay (1956) 4 D.L.R. (2d) 146 (N.s.s.C.); Pickering v Biship of Ely (1843), 2 Y. \& C. Ch. 249; Johnson v Shrewsbury and Birmingham Ry. (1853), 3 De. G.M. \& G. 914 .

3005 Eliz., c 4. The act is set out in full in Smith A Treatise on the Law of Master and Servant ( 3 rd ed 1870 ) $505^{-14}$. The legislation was modified over the years by a number of statutes including 20 Geo. II, c $19 ; 27$ Geo. II, c 6; 6 Geo. III, C 25; 4 Geo. IV, c 29; 4 Geo. Iv, C 34; and 10 Geo. Iv, C 52; the first schedule to the Master and Servant Act, 1867 , 30 \& 31 Vict., $c 141$, lists seventeen acts regulating employment contracts.

3015 Eliz., c 4, 59

302 Ibid. Other sections of the act dealt with freedom of travel, certificates and testimonials by masters confirming that the servant was not in breach of his service, the avoiding of contracts in contravention of the act, special rules relating to service by women, apprentices, and various procedural and jurisdictional issues.

303 Ibid s 47

30420 Geo. II, C 19, S 1

305 See R. v Hoseason (1811) 14 East. 605; 104 E.R. 734; Kirby v Simpson (1854) 10 Exch. 358; $15^{6}$ E.R. 482.

30620 Geo. II, C 19, s 2

3076 Geo. III, C 25, $\mathrm{s} 1$

308 Ibid. By 32 Geo. III, C 57, s 13 an apprentice who left his employment was liable to be whipped as well.

309 After 1824 two classes of case were contemplated. One was breach of a contract without ever having entered upon performance; the other was breach of a continuing employment relationship. The difference between the two was that the former would not give rise to criminal liability unless it was signed by both parties. $4 \mathrm{Geo}$. Iv, c 34 . See Smith, supra note 300 , at $457 ; R$. v Lord $(185$ o) 12 Q.B. $758 ; 116$ E.R. 1055 .

310 In 1867 the Master and Servant Act 1867, 30 \& 31 Vict., c 141, consolidated some seventeen earlier acts and continued the enforcement of employment contracts through criminal sanctions. In 1875 the Conspiracy and Protection of Property Act, $1875,38 \& 39$ Vict., $c_{13}, s_{5}$, created the offence of wilfully and maliciously breaking a contract of service, knowing or having reasonable grounds to believe that the consequences would endanger human life, cause serious bodily harm, or expose valuable personal or real property to destruction or serious injury. The Employers and Workmen Act, 1875, 38 \& 39 Vict., c 9o, s 3(3), expressly authorized the court to order performance of contracts of service, but the breach was not a criminal offence, and the court was one of civil jurisdiction. Ibid, ss 4,9 .

311 See Rider v Wood (1859), 1 L.T. (N.S.) 30; 29 L.J.M.C. 1. See also Youle v Mappin (1861) 6 H. \& N. $753 ; 15^{8 \text { E.R. } 311 .}$

312 Brown and Beattie Canadian Labour Arbitration (1979) 64; Brown, Remedies in arbitration: Fidelity to labour relations, in Hickling (ed) Current Problems in Labour Arbitration 1978 (1979), at 169, 180-3. Recent decisions, however, cast some degree of uncertainty on that unequivocal opinion. See Progressive Contracting Ltd. [1978] 1 W.L.A.C. $5_{4}$ (Mazko); Douglas College Technical and Vocational Institute (1977) 16 L.A.C. (2d) 139 (Munroe).

Authority to order reinstatement is now vested in labour arbitrators in all common law provinces. The Labour Relations Act, R.s.o. 1970, c 232, s 37(8); the Canada 
Labour Code, R.S.C. 1970 , C L-1, $S_{157}$ (d), as amended S.C. 1972, C 18 , s 1 ; The Alberta Labour Act, S.A. 1973, c 33, as amended, s 143(2); Labour Code, S.B.c. 1973 (2nd Sess.), c 1 22, s 98(d), as amended s.B.c. 1975, c 33, s 27; Manitoba Labour Relations Act, s.m. 1972, c 75, s 69(6) (continuing consolidation, c L 10); Industrial Relations Act, R.S.N.B. 1973, C I-4, s 76 (4): Labour Relations Act, R.S.N. 1970, c 191, s 26B(7) as amended, S.N. 1973, c 107 , s 2; Trade Union Act, S.N.S. 1972, c 19, S 41 (d); P.E.I. Labour Act, R.S.P.E.I. 1974, C L-1, s 36(7); Trade Union Act, s.s. 1972, c 137, s 25(3).

See Adams Grievance Arbitration of Discharge Cases: A Study of the Concepts of Industrial Discipline and Their Results (1978); Feller, A general theory of collective bargaining (1972) 61 Cal. L.R. 663, at 750 .

313 Zeller's (Western) Ltd. v Retail, Wholesale E Dept. Store Union, Local 995 et al. (1973) 40 D.L.R. (3d) 761 ; Sheddon et al. v Ontario Major Junior League Hockey et al. (1979) 83 D.L.R. (3d) 734

314 S.s. 1944, c 69

315 [1949] A.C.134; [1948] 4 D.L.R. 673, per Lord Simonds at 680, 681

316 R.S.C. 1970 , C.L-1; as amended by S.C. $1977-8$, c $27, \mathrm{~s} 21$

317 See Teamsters, Chauffeurs, Warehousemen and Helpers of America, Local I4I $\vee$ Harry Woods Transport Limited (1976) 76 c.L.L.c. 16, 055; Retail, Wholesale and Department Store Union, AFL-CIO-CLC et al. v Humpty Dumpty Foods Limited (1978), 78 c.L.L.c. 16; Canadian Union of Brewery Workers and Carling O'Keefe Limited [1975] 3 C.L.R.B.R. 148.

318 MacDonald v Rose (187o) 17 Gr. 657 (Ont. Ch. D); Lumley v Wagner (1852), i De G.M. \& G. 604; 42 E.R. 687; International Longshoremen's Association, Local 273 et al. v Maritime Employer's Association et al. (1979) 89 D.L.R. (3d) 289 (s.C.C.); Pacific Press Ltd. v Vancouver Typographical Union Local 226 (1970) 15 D.L.R. (3d) 212 ; Winnipeg Builders' Exchange et al. $\checkmark$ International Brotherhood of Electrical Workers, Local Union 2085 et al. (1966) 57 D.L.R. (2d) 141, affirmed [1967] S.C.R. 628. As Estey J put it in the Maritime Employer's Association Case (at 308): 'The effect of an injunction to cease from continuing an illegal strike is quite a different thing in reality from a mandatory order directing an opera singer to sing.'

Legislative orders of specific performance of labour contracts are notorious. Canadian Union of Postal Workers v Attorney-General of Canada (1979) 93 D.L.R. (3d) 148 (federal legislation ordering union members to work not contrary to Canadian Bill of Rights).

319 Moore, The emergence of new property conceptions in America (1943) 1 J. Leg. E Pol. Soc. 34, 53. See Meyers Ownership of Jobs: A Comparative Study (1964).

320 See Hamilton, Property rights in the market (1943) 1 J. Leg. E Pol. Soc. 10, 15.

321 Hughes Men and Their Work (1958) 78

322 Olson The Logic of Collective Action (1965) 137; Hughes, Professions (1963) 92 Daedalus $655-7$

323 Arnold The Folklore of Capitalism (1937) ch 7

324 Reich, supra note 28 . Reich, in a later article, defines 'entitlements' to include franchises, professional licences, union membership, employment contracts, and similar occupation-related benefits. Reich, Individual rights and social welfare: The emerging legal issues $(1965) 74$ Yale L.J. 1245, 1255. See also Glendon and Lev, Changes in the bonding of the employment relationship: An essay on the new property (1979) 20 Bost. Col. L.R. 457.

325 See Snaidach v Family Finance Corp. 395 U.s. 337 (1969) (due process protection from garnishment afforded to defendant-employees); Employee and Retirement Income Security Act Pub. L. No. 93-406, 88 Stat. 829 (vesting of pension rights).

326 The Employment Protection Act, 1975, 23 \& 24 Eliz. 2, c 71, ss 71, 72; Freedland, The Employment Protection Act 1975 - Individual aspects (1976), 39 Mod. L.R. 561, 570-1; Benedictus, Employment protection: New institutions and trade union rights (1976) 5 Industrial L.J. 12, 21; Arderman The Law of Unfair Dismissal (1978).

327 Employment Protection (Consolidation) Act 1978, c 44, ss 67-71

328 See Employment Protection Act, 1975, 23 \& 24 Eliz. 2, c 71 , ss 72(2)(b), 72(3).

329 Kahn-Freund, in Labour and the Law (2nd ed 1977) 179 expresses the point this way: 
'Such is the precarious compromise between the policies to avoid direct compulsion through the ultimate sanctions of contempt of court, and to make it as expensive as possible for employers to encroach upon their employees' freedom of organization.'

330 See The Prescription Act, 1832, 2 \& 3 Will. Iv, c 71 ; The Real Property Limitation Act, 1833, 3 \& 4 Will. Iv, c 27; The Real Property Act, 1845, 8 \& 9 Vict., c 106; The Conveyancing and Law of Property Act, 1881, 44 \& 45 Vict., c 41.

331 The first registration statute introduced in England in 1862 was an undeniable failure; only $4^{11}$ titles were registered under its provisions. See Whalen, supra note 256; Simpson, supra note 140, at 254. See The Land Registry Act, 1862, 25 \& 26 Vict., c 53. The act, which attempted to introduce registration of titles rather than registration of deeds by memorial, was voluntary, and few land-owners were willing to risk discovery of their insecure titles to their landed estates. The recommendations contained in the Report of the Commissioners Appointed to Consider the Subject of the Registration of Title with Reference to the Sale and Transfer of Land (Cmnd. 22 15,1857 ), not entirely reflected in the 1862 act, were enacted in the Land Transfer Act, 1875, 38 \& 39 Vict., c 87.

332 Dicey, supra note 33 , at 226

333 See DiCastri Thoms' Canadian Torrens System (1962) 16; McLeod, The Torrens system in Ontario (1909) 29 Can. L.T. 695. Marketability of land still plays a role in land registration reform. See Ontario Law Reform Commission Report on Land Registration (1971) 11, 28-30; Thornhill, How to simplify our titles (1889) 5 Law Q. Rev. $11,14$.

334 Dicey, supra note 33 , at 221,222 . One explanation for the failure of electoral reform in $183^{2}$ 'was that there could be no revolution in the distribution of political power without a revolution in the distribution of real property.' Turberville, supra note 76 , at 407. Thus, before thoughts turned to the more direct route of extending the franchise to all persons irrespective of wealth and property, reformers advocated the expropriation of private landowners as an assault on the property qualification which stood in the way of parliamentary reform. Denman Studies in Land Economy, The Place of Property (1978) 57. See Greenwood, Registration - or simplification of title (189o) 6 Law Q. Rev. 144; Holdsworth, The reform of the land law: An historical retrospect (1926), $4^{2} \mathrm{Law}$ Q. Rev. 158; Simpson Land Law and Registration (1976) 88.

335 As some would have it. See British Westinghouse Electric Co. v Underground Railways [1912] A.C. 673,679 .

336 Friedman, General theory of law and social change, in Ziegel (ed) Law and Social Change (1973) 17, 21

337 Graveson, The movement from status to contract (1941) 4 Mod. L.R. 261, 262; see also Kahn-Freund, A note on status and contract in British labour law (1967) 30 Mod. L.R. 635 . 